\title{
A Practical Guide for Commissioning Existing Buildings
}

\author{
Tudi Haasl \\ Portland Energy Conservation, Inc. \\ Portland, Oregon \\ Terry Sharp \\ Terry Sharp
Oak Ridge National Laboratory RECEIVED
Oak Ridge, Tennessee \\ DEC 131999 \\ O STI
}

April 1999

Prepared by

Portland Energy Conservation, Inc.

and

Oak Ridge National Laboratory

for the

Office of Building Technology,

State and Community Programs

U.S. Department of Energy

under contract DE-AC05-960R22464 


\section{DISCLAIMER}

This report was prepared as an account of work sponsored by an agency of the United States Government. Neither the United States Government nor any agency thereof, nor any of their employees, make any warranty, express or implied, or assumes any legal liability or responsibility for the accuracy, completeness, or usefulness of any information, apparatus, product, or process disclosed, or represents that its use would not infringe privately owned rights. Reference herein to any specific commercial product, process, or service by trade name, trademark, manufacturer, or otherwise does not necessarily constitute or imply its endorsement, recommendation, or favoring by the United States Government or any agency thereof. The views and opinions of authors expressed herein do not necessarily state or reflect those of the United States Government or any agency thereof. 


\section{DISCLAIMER}

\section{Portions of this document may be illegible in electronic image products. Images are produced from the best available original document.}


LIST OF FIGURES AND TABLES $\ldots \ldots \ldots \ldots \ldots \ldots$ vii

ACRONYMS AND ABBREVIATIONS ................ ix

ACKNOWLEDGMENTS ....................... xi

1 INTRODUCTION $\ldots \ldots \ldots \ldots \ldots \ldots \ldots \ldots \ldots \ldots \ldots \ldots \ldots \ldots \ldots \ldots \ldots$

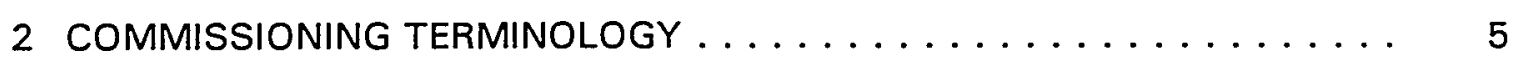

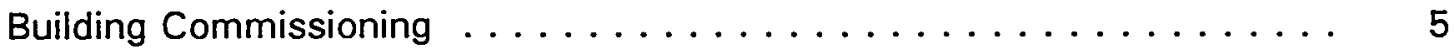

Existing-Building Commissioning, or Retrocommissioning ....... 5

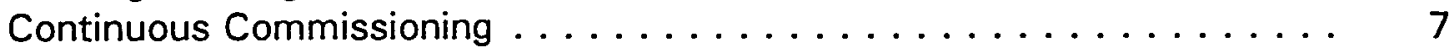

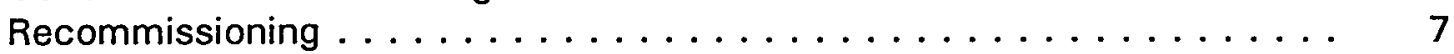

Commissioning Service Providers $\ldots \ldots \ldots \ldots \ldots \ldots$

3 BENEFITS AND COSTS OF COMMISSIONING EXISTING BUILDINGS $\ldots$

4 PREPARING FOR A RETROCOMMISSIONING PROJECT . . . . . . . . . 17

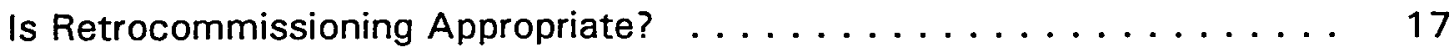

Is an ESPC Being Considered? . . . . . . . . . . . . . . . 18

What Resources Are Available...$\ldots \ldots \ldots \ldots$. . . . . . . . . 19

Who Needs to Be Convinced? ..................... 20

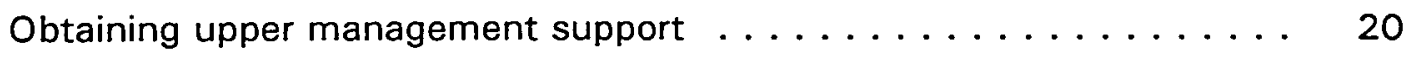

Obtaining building operating staff support ............. 21

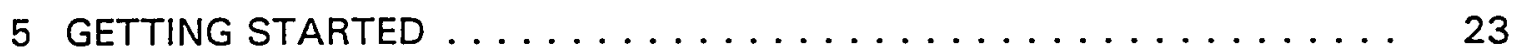

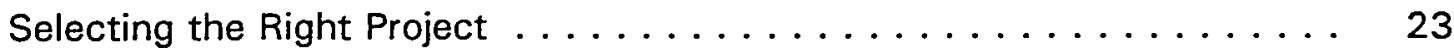

Energy management control systems . . . . . . . . . . . 24

Absence of major system problems ................. 24

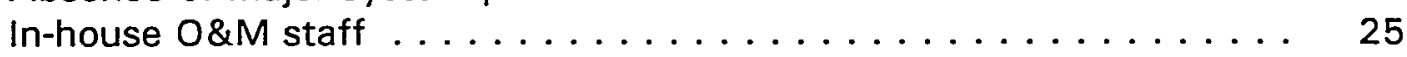

Accessible and up-to-date building documentation .......... 25

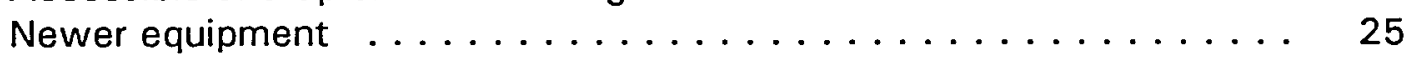

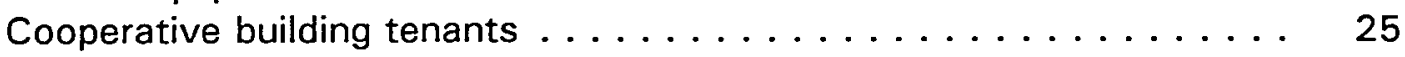

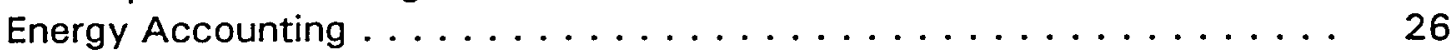

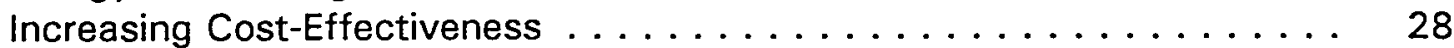

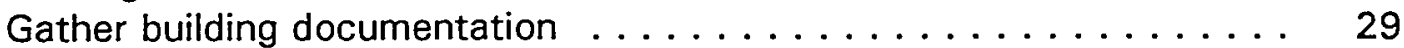

Perform appropriate preventive maintenance ............ 30

Perform simple repairs and improvements as the project progresses . . 30

Perform diagnostic monitoring and functional tests .......... 30

Implement selected improvements and repairs ........... 31

6 ROLES AND RESPONSIBILITIES OF PROJECT TEAM MEMBERS . . . . . . 33 
Building Owner or Owner's Representative . . . . . . . . . . . . . 34

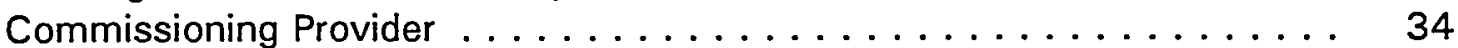

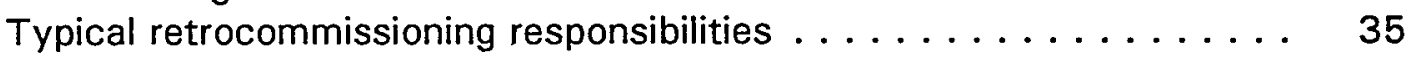

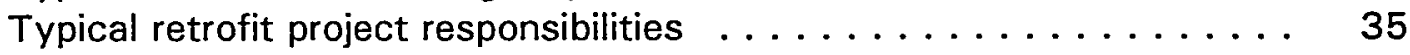

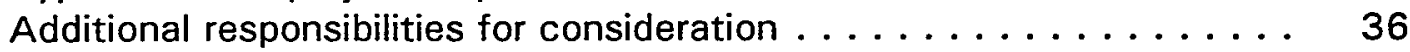

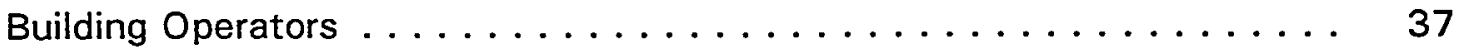

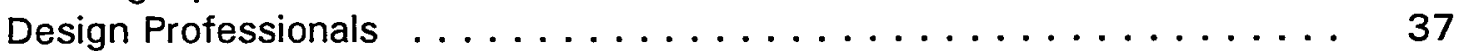

Contractors and Manufacturer Representatives . . . . . . . . . . 38

Testing Specialists . . . . . . . . . . . . . . . . . 38

Utility or Government Representative . . . . . . . . . . . . . . . 39

7 RETROCOMMISSIONING IN ACTION ................ 41

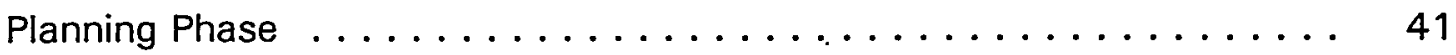

Developing and communicating the objectives ........... 41

Choosing the team and hiring the commissioning provider ....... 46

Reviewing and updating building documentation ........... 49

Developing the plan and holding a scoping meeting .......... 49

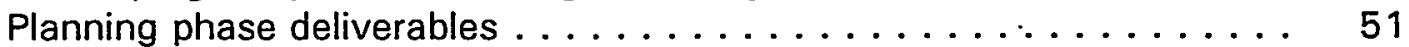

Investigation Phase ...................... 51

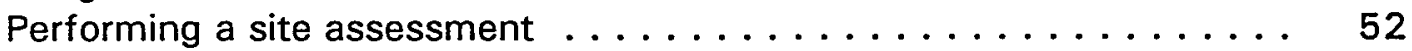

Developing the Master List of deficiencies and potential

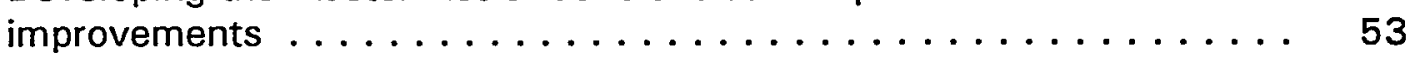

Developing the diagnostic monitoring and test plans ........ 53

Implementing the diagnostic monitoring and test plans : . . . . . 56

Selecting the most cost-effective opportunities for implementation ... 57

Investigation phase deliverables . . . . . . . . . . . 57

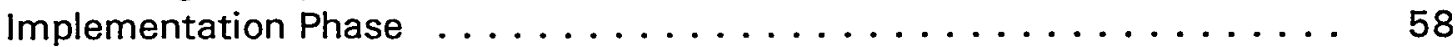

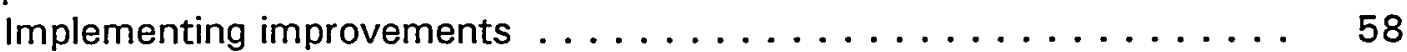

Retesting and remonitoring ................. 59

Implementation phase deliverables . . . ........... 59

Project Hand-Off Phase ...................... 59

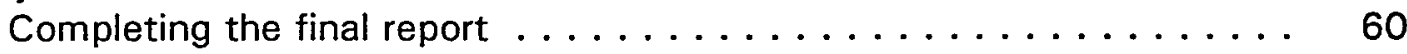

Maintaining the investment benefits ............... 61

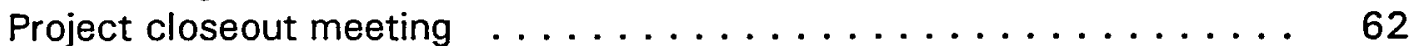

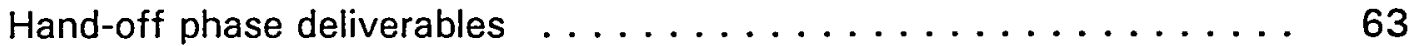

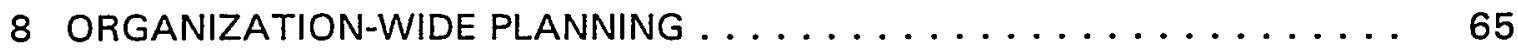

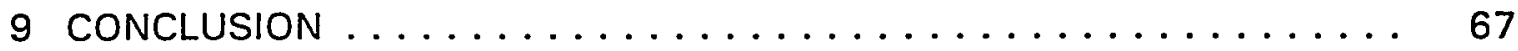

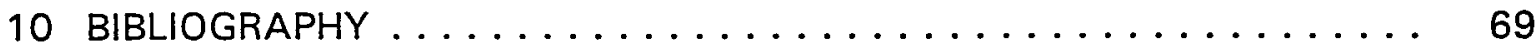

\section{APPENDICES}

A Sources for Commissioning Guidelines, Guide Specifications, and Sample Functional Performance Tests . . . . . . . . . . . . . . . . A-1

B Building Information Summary . . . . . . . . . . . . . . B-1

C Checklist of Building Documentation $\ldots \ldots \ldots \ldots \ldots \ldots \ldots \ldots \ldots$ 


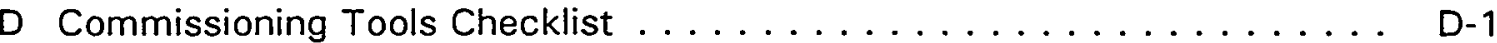

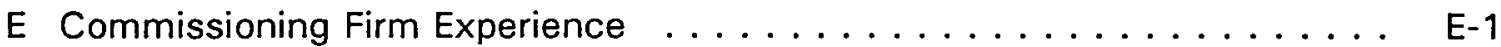

F Request for Proposal Checklist for Retrocommissioning Services ..... F 1

G Sample Retrocommissioning Plan ................. G-1

H Sample Site Assessment Forms .......................

I Sample Master List ... . . . . . . . . . . . . . . . . . . 1-1

$\mathrm{J}$ Sample Diagnostic Monitoring and Trending Plans . . . . . . . . . . . J J

$\mathrm{K}$ Sample Functional Performance Tests .................. K-1 


\section{Figures and Tables}

\section{Figures}

1 The phases and activities of the retrocommissioning process . . . . . 42

2 Example of prioritized, written objectives for a commissioning

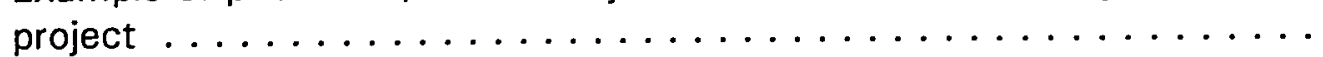

3 Example of data analysis using data derived from a portable

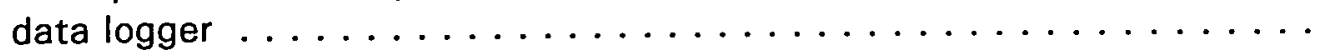

4 Example of a list of recommended capital improvements . . . . . . . . 61

\section{Tables}

1 The four phases of the retrocommissioning process $\ldots \ldots \ldots \ldots$

2 New-construction commissioning vs retrocommissioning ......... 6

3 Benefits of commissioning existing buildings . . . . . . . . . 9

4 Summary of recent cost and savings for recently commissioned existing buildings ....................... 10

5 Cost of losing a tenant .................... 16

6 Characteristics that improve retrocommissioning value $\ldots \ldots \ldots \ldots$

7 Distribution of annual total energy use intensities (EUls) for commercial buildings .................... 27

8 Summary of retrocommissioning activities and products ........ 43 


\section{Abbreviations and Acronyms}

$\begin{array}{ll}\text { A/C } & \text { air conditioner } \\ \text { DOE } & \text { U.S. Department of Energy } \\ \text { EMCS } & \text { energy management control system } \\ \text { EPA } & \text { U.S. Environmental Protection Agency } \\ \text { ESPC } & \text { energy savings performance contract } \\ \text { EUI } & \text { energy use index } \\ \text { HVAC } & \text { heating, ventilating and air-conditioning } \\ \text { IAQ } & \text { indoor air quality } \\ \text { M\&V } & \text { measurement and verification } \\ \text { O\&M } & \text { operation and maintenance } \\ \text { ORNL } & \text { Oak Ridge National Laboratory } \\ \text { OSA } & \text { outside air } \\ \text { OSHA } & \text { Occupational Safety and Health Administration } \\ \text { PM } & \text { preventive maintenance } \\ \text { RFP } & \text { request for proposal } \\ \text { RFO } & \text { request for qualifications } \\ \text { ROI } & \text { return on investment } \\ \text { TAB } & \text { testing, adjusting and balancing } \\ \text { TN } & \text { total number } \\ \text { TOD } & \text { time of day } \\ \text { VAV } & \text { variable-air-volume } \\ \text { VFD } & \text { variable frequency drive }\end{array}$




\section{Acknowledgments}

The authors would like to express their appreciation to Peter Herzog of Herzog/Wheeler and Associates and to Bil Pletz for their thorough reviews and insightful comments that helped improve this guide. 


\section{Introduction}

B

uilding commissioning is rapidly becoming an important new field. More and more architectural and engineering firms are including commissioning services as a core business component. For the most part, building commissioning is a term associated with new construction projects as a process of ensuring that new buildings and their systems perform as designed. Commissioning is integrated into the construction process to ensure that owners and investors get good buildings for their investments.

Unfortunately, most buildings have never gone through any type of commissioning or quality assurance process and are therefore performing well below their potential. Even if building staff have been able to work out most of the "bugs" in the building systems, they are often forced to solve problems under severe time constraints and without the benefit of proper documentation. Having to address such problems too fast and without good information usually results in "quick and dirty" solutions, and such makeshift solutions lead to other building problems that often are invisible yet costly.

To improve buildings and capture the sizable opportunities that exist within them, commissioning principles are being applied to existing buildings more and more often. Fortunately, commissioning of existing buildings-also known as retrocommissioning ${ }^{1}$ - when appropriately

Commissioning of existing buildings, when appropriately applied, is going beyond quick-fix solutions to systematically optimize building systems so that they operate efficiently and effectively, often eliminating the need for costly capital improvements. applied goes beyond quick-fix solutions to systematically optimize building systems so that they operate efficiently and effectively, often eliminating the need for costly capital improvements. Not only does retrocommissioning identify problems that occurred at construction just as traditional commissioning does, but it also identifies and solves problems. that have developed during the building's life.

In his book Energy-Efficient Operation of Commercial Buildings, Peter Herzog describes the three fundamental components of an organization's energy management program as

${ }^{1}$ The term retrocommissioning is used by Rick Casault, An Integrated Approach to Building Commissioning, ASHRAE Professional Development Seminar, 1998-. This is one of several seminars sponsored by ASHRAE; see http://www.ashrae.org/EDUC/pdsinfo.htm. 
- efficient purchasing - purchasing energy at the lowest available unit cost.

- efficient operation - operating the equipment that consumes energy as efficiently as possible, and

- efficient equipment - upgrading or replacing existing equipment with more energyefficient versions whenever it is cost-effective to do so. ${ }^{2}$

Herzog notes that most energy management programs focus on purchasing energy and installing energy-efficient technologies, with little emphasis placed on efficient operation. Yet, efficient operation, although it is the least understood of the components, can offer the highest potential for savings with little or no capital outlay. A key goal of retrocommissioning is achieving this efficient operation.

Retrocommissioning seeks to ensure the functionality of equipment and systems and also to optimize how they operate together in order to reduce energy waste and improve building operation and comfort. Thus, the goal of ensuring comfort and productivity of the building occupants accompanies the goal of cost savings.

"Do my existing buildings need commissioning?" an owner may ask. Many existing buildings are limping along in terms of performance, and unfortunately, most owners don't know it. As long as building systems maintain a reasonably comfortable environment, nothing appears to be wrong. Many problems are noticed only when a catastrophic failure or a visible consequence occurs. For example, when unnecessarily large volumes of outdoor air are drawn into a building, excessive heating and cooling energy are used. As long as the heating and cooling systems have the capacity to handle this increased air volume, however, the problem goes unnoticed. Other common problems that drive energy costs up but may or may not cause comfort or other visible problems include

- adjustable speed drives that are no longer adjusting appropriately,

- time clocks that are circumvented or set up improperly,

- equipment that is running more than necessary or running inefficiently because of improper operating strategies,

- energy management systems that were never installed or programmed to take full advantage of their capabilities or that have degraded over time, and

- controls that are out of calibration or are improperly sequencing.

2 Peter Herzog, Energy-Efficient Operation of Commercial Buildings: Redefining the Energy Manager's Job (New York: McGraw-Hill, 1996). 
Each of these problems can have a sizable effect on the economics of owning and operating a building. Not only can energy costs become excessive, but also capital dollars invested may cease to provide a return. These types of problems are typical in many buildings. Commissioning existing systems not only can find and correct these problems, but can optimize systems so that they operate in an integrated manner. These are just some of the reasons that retrocommissioning provides attractive returns to owners and managers.

Systems that are functioning improperly can have a sizable effect on the economics of owning and operating a building.

Retrocommissioning is widely applicable because operating and maintenance (O\&M) problems are very common in buildings. Commissioning can benefit the "good, the bad, and the ugly" building. Which building type do you have and which type benefits the most from retrocommissioning? The bad building has numerous, obvious, and often complex $O \& M$ problems. It usually has attractive retrocommissioning opportunities. The ugly has these combined with needs for major capital improvements. Commissioning for both the existing equipment and new equipment is a good choice for this building type. Although "the bad and the ugly" stand to achieve the most benefit from retrocommissioning, the so-called "good" building often has lots of improvement potential as well, especially where multiple and more complex systems are used. Numerous well-designed, -constructed, and -operated buildings have major cost-saving opportunities. Often these opportunities are invisible to the owner but readily detectable through retrocommissioning. Chapter 5 discusses the many factors to consider when deciding whether an existing building is a good candidate for retrocommissioning. In most cases, energy savings alone makes retrocommissioning an attractive business investment.

How do / commission my existing buildings? is another question owners and managers often ask. Retrocommissioning is implemented as the four-part process outlined in Table 1.

Retrocommissioning begins with the planning phase, which consists of identifying

Table 1. The four phases of the retrocommissioning process

$\begin{array}{ll}\text { Planning phase } & \begin{array}{l}\text { Decide which building systems should be analyzed and } \\ \text { assign responsibilities }\end{array} \\ \text { Investigation phase } & \begin{array}{l}\text { Determine how the selected systems are supposed to } \\ \text { operate, measure and monitor how they operate, and } \\ \text { prepare a prioritized list of the operating deficiencies foul }\end{array} \\ \text { Implementation phase } & \begin{array}{l}\text { Correct the highest priority operating deficiencies and } \\ \text { verify proper operation }\end{array}\end{array}$

Hand-off phase

Report improvements made and show the building owner/operator-how-to-sustain-proper-operation 
project objectives, targeting systems for improvements, and defining tasks and responsibilities. A plan for conducting the work results. An investigation phase follows, in which on-site assessment and testing are conducted. This phase allows deficiencies to be found and the scope of work to be refined. Once the scope is finalized, the improvements are then installed in an implementation phase, and their success is validated. Finally, the completed improvements are "handed-off" to the owner along with information and knowledge gained during the process to help ensure long-term performance for the owner.

This guide is written to educate building owners and managers about the retrocommissioning process and help them obtain the most value out of commissioning their existing buildings. It discusses commissioning terminology, how to get started, the phases and steps in the retrocommissioning process, the roles and responsibilities of the team members, retrocommissioning costs and benefits, how to increase cost effectiveness, and more. It is not a detailed how-to manual for commissioning service providers, although it can be useful for commissioning providers who are interested in understanding the owner's and manager's roles and expectations. The guide specifically targets those who are interested in obtaining cost-effective O\&M improvements that do not entail a large capital investment. 


\section{2 \\ Commissioning Terminology}

he following discussion of commissioning terminology provides clear definitions for use throughout this document. The definitions are based on current literature and discussions with commissioning professionals.

\section{Building Commissioning}

It is generally accepted that building commissioning is a method of risk reduction for new construction projects. Commissioning activities for new construction, summarized in Table 2, follow the construction process from pre-design through construction and acceptance. In addition, new construction commissioning may include all building systems (security, fire, life and safety, HVAC, lighting, electrical, etc.). Commissioning is defined in ASHRAE Guideline 1-1996 as the process of ensuring that systems are designed, installed, functionally tested, and capable of being operated and maintained to perform in conformity with the design intent. The guideline states that "commissioning begins with planning and includes design, construction, startup, acceptance and training, and can be applied throughout the life of the building."

The terms building commissioning and building-systems commissioning are often used interchangeably. If anything, building-systems commissioning is more specific in that it generally includes only the dynamic or energy-using systems in the building, whereas building commissioning may also include static systems such as the building envelope. In any case, the primary emphasis in commissioning new construction or new installations is on ensuring that building systems meet design intent and provide the owner what he or she expects.

\section{Existing-Building Commissioning, or Retrocommissioning}

Existing-building commissioning, also known as retrocommissioning, is an event in the life of a building that applies a systematic investigation process for improving and optimizing a building's O\&M. As Table 2 indicates, many of its components are similar to those for new-construction commissioning. Retrocommissioning, however, occurs after construction, as an independent process, and its focus is usually on energy-using equipment such as mechanical equipment, lighting, and related controls. It may or may not emphasize bringing the building back to its original intended design. In fact, the 
Table 2. New-construction commissioning vs retrocommissioning

\begin{tabular}{|c|c|}
\hline New-construction commissioning & Retrocommissioning (existing equipment) \\
\hline $\begin{array}{l}\text { 1. Conception or pre-design phase } \\
\text { (a) Develop commissioning objectives } \\
\text { (b) Hire commissioning provider } \\
\text { (c) Develop design phase commissioning } \\
\text { requirements } \\
\text { (d) Choose the design team }\end{array}$ & $\begin{array}{l}\text { 1. Planning phase } \\
\text { (a) Develop commissioning objectives } \\
\text { (b) Hire commissioning provider } \\
\text { (c) Review available documentation and } \\
\text { obtain historical utility data } \\
\text { (d) Develop retrocommissioning plan }\end{array}$ \\
\hline $\begin{array}{l}\text { 2. Design phase } \\
\text { (a) Commissioning review of design intent } \\
\text { (b) Write commissioning specifications for bid } \\
\text { documents } \\
\text { (c) Award job to contractor } \\
\text { (d) Develop commissioning plan }\end{array}$ & [No design phase activities] \\
\hline $\begin{array}{l}\text { 3. Construction/installation phase } \\
\text { (a) Gather and review documentation } \\
\text { (b) Hold commissioning scoping meeting and } \\
\text { finalize plan } \\
\text { (c) Develop pre-test checklists } \\
\text { (d) Start up equipment or perform pre-test } \\
\text { checklists to ensure readiness for } \\
\text { functional testing during acceptance }\end{array}$ & $\begin{array}{l}\text { 2. Investigation phase } \\
\text { (a) Perform site assessment } \\
\text { (b) Obtain or develop missing documentation } \\
\text { (c) Develop and execute diagnostic } \\
\text { monitoring and test plans } \\
\text { (d) Develop and execute functional test plans } \\
\text { (e) Analyze results } \\
\text { (f) Develop Master List of deficiencies and } \\
\text { improvements } \\
\text { (g) Recommend most cost-effective } \\
\text { improvements for implementation }\end{array}$ \\
\hline $\begin{array}{l}\text { 4. Acceptance phase } \\
\text { (a) Execute functional tests and diagnostics } \\
\text { (b) Fix deficiencies } \\
\text { (c) Retest and monitor as needed } \\
\text { (d) Verify operator training } \\
\text { (e) Review O\&M manuals } \\
\text { (f) Building/retrofit accepted by owner }\end{array}$ & $\begin{array}{l}\text { 3. Implementation phase } \\
\text { (a) Implement repairs and improvements } \\
\text { (b) Retest and remonitor for results } \\
\text { (c) Fine-tune improvements if needed } \\
\text { (d) Revise estimated energy savings } \\
\text { calculations }\end{array}$ \\
\hline $\begin{array}{l}\text { 5. Post-acceptance phase } \\
\text { (a) Prepare and submit final report } \\
\text { (b) Perform deferred tests (if needed) } \\
\text { (c) Develop recommissioning plan/schedule }\end{array}$ & $\begin{array}{l}\text { 4. Project hand-off and integration phase } \\
\text { (a) Prepare and submit final report } \\
\text { (b) Perform deferred tests (if needed) } \\
\text { (c) Develop recommissioning plan/schedule }\end{array}$ \\
\hline
\end{tabular}


original design documentation may no longer exist or may be irrelevant.

Retrocommissioning is applied to buildings that have not previously been

commissioned. Retrocommissioning ensures system functionality. It is an inclusive and systematic process intended not only to optimize how equipment and systems operate, but also to optimize how the systems function together. Although retrocommissioning may result in recommendations to investigate further capital improvements, O\&M tuneup activities and diagnostic testing are primarily used to optimize the building systems. The goals and objectives for applying the process, as well as the level of rigor, may vary, depending on the current needs of the owner, the budget, and the condition of the equipment. The retrocommissioning process most often focuses on the dynamic energy-using systems with the goal of reducing energy waste, obtaining energy cost savings for the owner, and identifying and fixing existing problems.

\section{Continuous Commissioning}

The continuous commissioning process involves many of the same planning elements and investigation procedures as retrocommissioning. Its objectives are essentially the same. And like retrocommissioning, it is a systematic way of identifying and correcting building system problems and optimizing system performance in existing buildings. Continuous commissioning, however, more rigorously addresses the issue of persistence. A key goal is to ensure that building systems remain optimized continuously. To achieve this, continuous commissioning requires benchmarking preand post-energy use via metering equipment that is permanently installed. Data are then continuously gathered and compared against the post-commissioning benchmarks to ensure that the building systems function optimally throughout their lives.

\section{Recommissioning}

The term recommissioning is a confusing and often misused term. Simply put, recommissioning can occur only if a building was commissioned at some point in its life. Once a building has undergone either building commissioning as part of new construction or retrocommissioning as defined above, the periodic recommissioning ensures that the original results persist. Therefore, recommissioning is a periodic event that reapplies the original commissioning tests in order to keep the building operating according to design or current operating needs. In the best of worlds, recommissioning becomes part of a facility's ongoing $O \& M$ program. Recommissioning may need to occur only every 3 to 5 years. However, the frequency of recommissioning should be based on the complexity of the systems involved and the dynamic needs of the occupants. If there are frequent build-outs or changes in building use, recommissioning should be applied more often.

This document does not address recommissioning in any detail, but focuses entirely on retrocommissioning. 


\section{Commissioning Service Providers}

The commissioning service provider, or commissioning provider, is often referred to as a commissioning agent, commissioning engineer, or commissioning expert. For projects involving the installation of new equipment or systems, the service provider is often referred to as the commissioning authority or agent. However, the use of the term agent is controversial because it implies having legal authority on behalf of the owner. The commissioning provider is hired or assigned by the owner. 


\section{Benefits and Costs of Commissioning Existing Buildings}

T

he benefits of retrocommissioning are numerous. Many of those most important to building owners and occupants are summarized in Table 3.

Table 3. Benefits of commissioning existing buildings

- Identifies system operating, control, and maintenance problems

- Aids in long-term planning and major maintenance budgeting

- Helps ensure a healthy, comfortable, and productive working environment for occupants

- Reduces energy waste and ensures that energy-using equipment operates efficiently

- Provides energy cost savings that often pay back investment

- Reduces maintenance costs; reduces premature equipment failure

- Provides complete and accurate building documentation; expedites troubleshooting

- Provides appropriate training to operating staff to increase skill levels; increases staff effectiveness in serving customers or tenants

- Reduces risk and increases the asset value of the building

A 1996 study of the cost-effectiveness of retrocommissioning in 44 existing buildings revealed attractive paybacks, even when estimates were based solely on energy costs savings. Table 4 summarizes the 44 buildings that were retrocommissioned. Retrocommissioning proved to have modest project costs of between $\$ 10,000$ and $\$ 52,000$, resulting in whole-building energy savings of $5-15 \%$. Based on energy savings alone, for an investment of 5 to 43 cents per square foot, commissioning existing buildings delivered simple paybacks that rarely exceeded 4 years-and were often 2 years or less. ${ }^{1}$ For building owners and managers these are

'J. Gregerson, "Cost Effectiveness of Commissioning 44 Existing Buildings," in Proceedings of the National Conference on Building Commissioning (Huntington Beach, Calif., April 28-30, 1997). 
Table 4. Summary of recent costs and savings for recently commissioned existing buildings

\begin{tabular}{|c|c|c|c|c|c|c|c|c|}
\hline \multirow{2}{*}{$\begin{array}{l}\text { Building name or } \\
\text { location; type }\end{array}$} & \multirow{2}{*}{$\begin{array}{l}\text { Area } \\
\left(\mathrm{ft}^{2}\right)\end{array}$} & \multirow{2}{*}{$\begin{array}{l}\text { Ending } \\
\text { date }\end{array}$} & \multirow{2}{*}{$\begin{array}{l}\text { Pre-comm. } \\
\text { energy } \\
\text { cost } \\
\left(\$ / \mathrm{ft}^{2} / \mathrm{yr}\right)\end{array}$} & \multicolumn{2}{|c|}{ Commissioning cost } & \multicolumn{2}{|c|}{ Energy cost savings } & \multirow{2}{*}{$\begin{array}{l}\text { Simple } \\
\text { payback } \\
\text { (years) }\end{array}$} \\
\hline & & & & Total \$ & $\$ / \mathrm{ft}^{2}$ & $\$ / y r$ & $\begin{array}{c}\% \text { of } \\
\text { total cost }\end{array}$ & \\
\hline \multicolumn{9}{|c|}{ 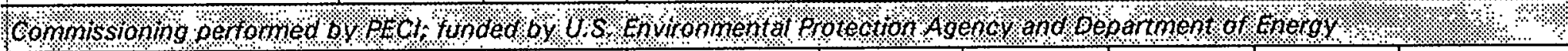 } \\
\hline Oregon; office & 278,000 & 1995 & 1.25 & $12,745^{a}$ & 0.05 & 8,145 & 2.3 & 1.6 \\
\hline $\begin{array}{l}\text { Citizen's Plaza, } \\
\text { Tennessee; office }\end{array}$ & 250,000 & 1995 & 1.81 & $23,967^{a}$ & 0.10 & 42,045 & 9.3 & 0.6 \\
\hline Arizona; office & 80,000 & 1995 & 1.95 & $14,546^{a}$ & 0.18 & 16,194 & 10.4 & 0.9 \\
\hline Colorado; retail & 122,000 & 1995 & 0.88 & $11,310^{a}$ & 0.09 & 13,779 & 12.8 & 0.8 \\
\hline Massachusetts; retail & 107,000 & 1995 & 2.40 & $12,801^{a}$ & 0.12 & 8,042 & 3.1 & 1.6 \\
\hline \multicolumn{9}{|c|}{ 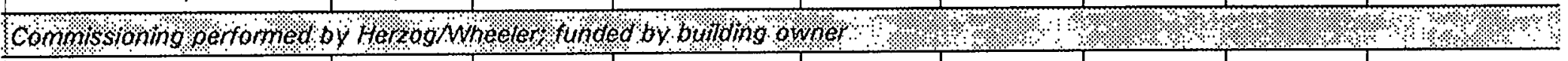 } \\
\hline High-tech research facility & 44,000 & 1984 & 4.35 & 14,000 & 0.32 & 59,840 & 31.3 & 0.2 \\
\hline \multicolumn{9}{|c|}{ 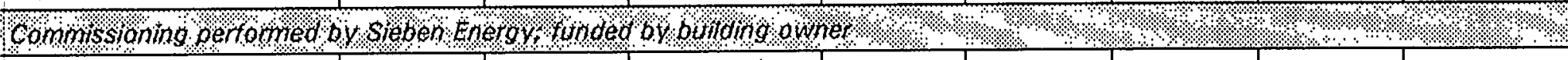 } \\
\hline 203 N. LaSalle St.; office & 623,000 & 1995 & $1.28^{b}$ & 80,000 & 0.13 & $150,000^{c}$ & 18.8 & 0.5 \\
\hline \multicolumn{9}{|c|}{ 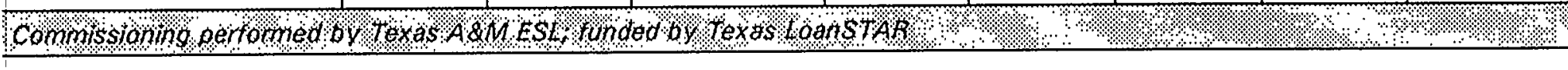 } \\
\hline \multicolumn{9}{|l|}{ State Capitol Complex } \\
\hline $\begin{array}{l}\text { Capitol Building; computer } \\
\text { facilities/office }\end{array}$ & 282,499 & 1996 & 1.63 & $24,000^{d}$ & 0.08 & 88,812 & 19.2 & 0.3 \\
\hline $\begin{array}{l}\text { S. F. Austin Building \& } \\
\text { CP; computer } \\
\text { facilities/office }\end{array}$ & 470,000 & 1993 & 1.24 & $28,000^{d}$ & 0.06 & 30,385 & 5.2 & 0.9 \\
\hline $\begin{array}{l}\text { John H. Reagan Building; } \\
\text { computer facilities/office }\end{array}$ & 169,756 & 1996 & 1.56 & $24,000^{d}$ & 0.14 & 50,680 & 19.2 & 0.5 \\
\hline
\end{tabular}




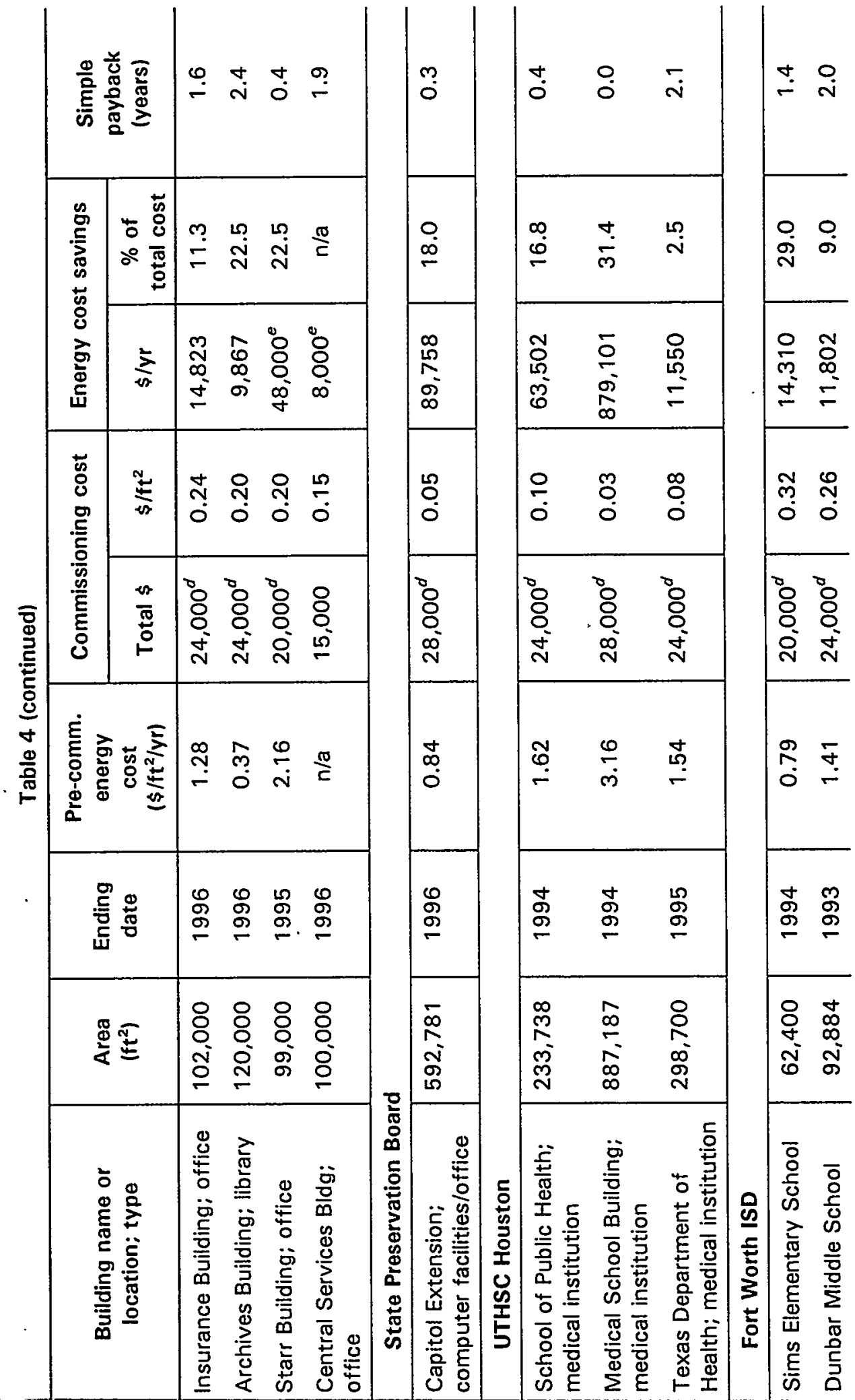


Table 4 (continued)

\begin{tabular}{|c|c|c|c|c|c|c|c|c|}
\hline \multirow{2}{*}{$\begin{array}{l}\text { Building name or } \\
\text { location; type }\end{array}$} & \multirow{2}{*}{$\begin{array}{l}\text { Area } \\
\left(\mathrm{ft}^{2}\right)\end{array}$} & \multirow{2}{*}{$\begin{array}{l}\text { Ending } \\
\text { date }\end{array}$} & \multirow{2}{*}{$\begin{array}{c}\text { Pre-comm. } \\
\text { energy } \\
\text { cost } \\
\left(\$ / \mathrm{ft}^{2} / \mathrm{yr}\right)\end{array}$} & \multicolumn{2}{|c|}{ Commissioning cost } & \multicolumn{2}{|c|}{ Energy cost savings } & \multirow{2}{*}{$\begin{array}{c}\text { Simple } \\
\text { payback } \\
\text { (years) }\end{array}$} \\
\hline & & & & Total \$ & $\$ / \mathrm{ft}^{2}$ & $\$ / y r$ & $\begin{array}{c}\% \text { of } \\
\text { total cost }\end{array}$ & \\
\hline \multicolumn{9}{|l|}{ UTMDA Cancer Center } \\
\hline $\begin{array}{l}\text { Boiler Room; medical } \\
\text { institution }\end{array}$ & 412,872 & 1994 & 1.72 & $28,000^{d}$ & 0.07 & 154,660 & 21.8 & 0.2 \\
\hline $\begin{array}{l}\text { Basic Research; medical } \\
\text { institution }\end{array}$ & 120,376 & 1994 & 3.77 & $24,000^{d}$ & 0.20 & 208,857 & 46.1 & 0.1 \\
\hline $\begin{array}{l}\text { Old Clinic \& Lutheran } \\
\text { Pavillion; medical } \\
\text { institution }\end{array}$ & 499,013 & 1994 & 2.05 & $28,000^{d}$ & 0.06 & 397,749 & 38.8 & 0.1 \\
\hline $\begin{array}{l}\text { New Clinic; medical } \\
\text { institution }\end{array}$ & 276,466 & 1995 & 1.59 & $24,000^{d}$ & 0.09 & 209,164 & 47.5 & 0.1 \\
\hline \multicolumn{9}{|l|}{ UTMB Galveston } \\
\hline $\begin{array}{l}\text { John Sealy North; medical } \\
\text { institution }\end{array}$ & 54,494 & 1993 & 6.61 & $20,000^{d}$ & 0.37 & 177,984 & 49.4 & 0.1 \\
\hline $\begin{array}{l}\text { Clinical Sciences; medical } \\
\text { institution }\end{array}$ & 124,870 & 1995 & 2.83 & $24,000^{d}$ & 0.19 & 23,638 & 6.7 & 1.0 \\
\hline $\begin{array}{l}\text { Basic Sciences; medical } \\
\text { institution }\end{array}$ & 137,856 & 1993 & 4.00 & $24,000^{d}$ & 0.17 & 235,151 & 42.7 & 0.1 \\
\hline Moody Memorial; library & 67,380 & 1994 & 2.48 & $20,000^{d}$ & 0.30 & 35,064 & 21.0 & 0.6 \\
\hline $\begin{array}{l}\text { John Sealy South; medical } \\
\text { institution }\end{array}$ & 373,085 & 1994 & 2.48 & $28,000^{d}$ & 0.08 & 176,904 & 19.1 & 0.2 \\
\hline
\end{tabular}




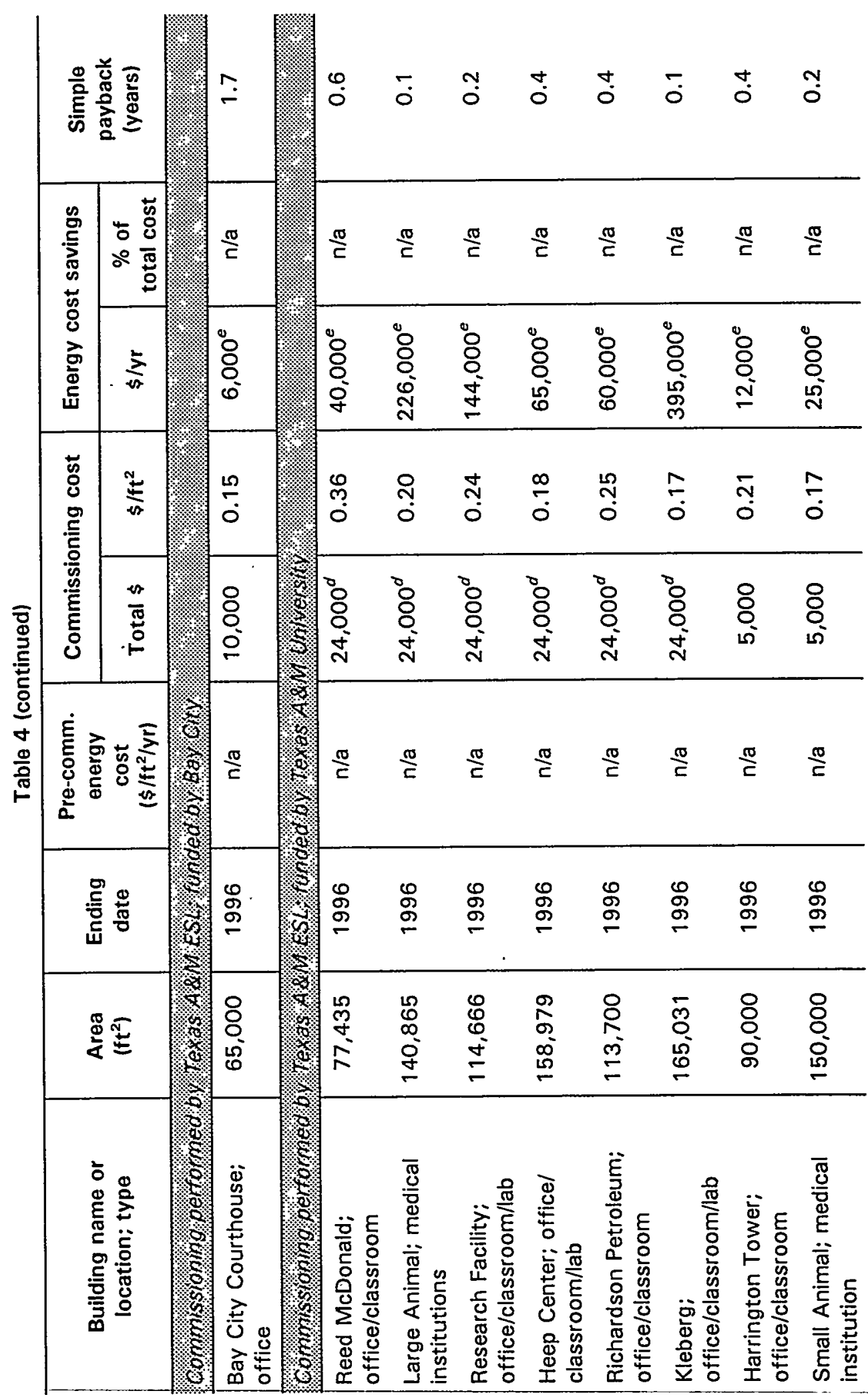


Table 4 (continued)

\begin{tabular}{|c|c|c|c|c|c|c|c|c|}
\hline \multirow{2}{*}{$\begin{array}{l}\text { Building name or } \\
\text { location; type }\end{array}$} & \multirow{2}{*}{$\begin{array}{l}\text { Area } \\
\left(\mathrm{ft}^{2}\right)\end{array}$} & \multirow{2}{*}{$\begin{array}{l}\text { Ending } \\
\text { date }\end{array}$} & \multirow{2}{*}{$\begin{array}{c}\text { Pre-comm. } \\
\text { energy } \\
\text { cost } \\
\left(\$ / \mathrm{ft}^{2} / \mathrm{yr}\right)\end{array}$} & \multicolumn{2}{|c|}{ Commissioning cost } & \multicolumn{2}{|c|}{ Energy cost savings } & \multirow{2}{*}{$\begin{array}{c}\text { Simple } \\
\text { payback } \\
\text { (years) }\end{array}$} \\
\hline & & & & Total \$ & $\$ / \mathrm{ft}^{2}$ & $\$ / y r$ & $\begin{array}{c}\% \text { of } \\
\text { total cost }\end{array}$ & \\
\hline \multicolumn{8}{|c|}{ 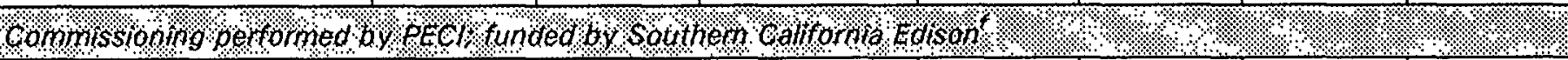 } & \\
\hline Retail & 146,000 & 1994 & 2.09 & 41,555 & 0.28 & $21,900^{d}$ & 7.4 & 1.9 \\
\hline Office & 152,000 & 1994 & 1.64 & 45,065 & 0.30 & $12,160^{d}$ & 5.2 & 3.7 \\
\hline Nordstrom; retail & 170,000 & 1994 & 2.26 & 52,336 & 0.31 & $42,500^{d}$ & 11.2 & 1.2 \\
\hline Office & 48,000 & 1994 & 1.25 & 16,634 & 0.35 & $16,320^{d}$ & 27.0 & 1.0 \\
\hline Office & 50,000 & 1994 & 1.82 & 21,713 & 0.43 & $11,000^{d}$ & 12.2 & 2.0 \\
\hline Office & 120,000 & 1994 & 1.45 & 16,454 & 0.14 & $3,600^{d}$ & 2.4 & 4.6 \\
\hline
\end{tabular}

Notes: $\mathrm{n} / \mathrm{a}=$ information was not available.

Source: Adapted from Gregerson, "Cost Effectiveness of Commissioning 44 Existing Buildings."

${ }^{a}$ Commissioning cost included facility staff time for these buildings. This amount was not included in the costs of other projects.

${ }^{b}$ Energy cost excludes cost of tenant lighting and plug loads for this building.

${ }^{c}$ Savings were estimated from utility bills and/or simplified engineering calculations for these buildings.

${ }^{d}$ Commissioning cost per building is estimated for these buildings, based on known project cost (which included several

buildings). ESL estimated the cost per building to be $\$ 20,000$ for buildings under $75,000 \mathrm{ft}^{2}, \$ 24,000$ for buildings from 75,000 to $300,000 \mathrm{ft}^{2}$, and $\$ 28,000$ for buildings over $300,000 \mathrm{ft}^{2}$.

Annual commissioning savings are projected based on measured savings for less than a full year.

${ }^{f}$ Energy cost, savings, and simple payback include electricity only for these six buildings. 
attractive figures, demonstrating that retrocommissioning is an effective, low-cost method to improve buildings and reduce operating costs.

The study showed that retrocommissioning costs vary according to the complexity of the systems, the number of pieces of equipment, and the objectives or scope of the retrocommissioning project rather than by building type. Retrocommissioning costs for only 10 of the buildings exceeded 28 cents per square foot. Yet, 9 of these 10 had simple paybacks of 2 years or less. The buildings ranged from medical facilities and schools to office buildings. The actual project cost for these 10 buildings ranged from $\$ 14,000$ to $\$ 52,000$, but for the majority ( 8 buildings) project costs were about $\$ 24,000$. The higher cost per square foot for these buildings was mostly a function of their smaller size. Only two of them were over $100,000 \mathrm{ft}^{2}$. The rest were between 44,000 and $77,000 \mathrm{ft}^{2}$. In comparison, the largest building in the study $\left(623,000 \mathrm{ft}^{2}\right)$ cost the most to commission- $\$ 80,000$-but the cost per square foot was only 13 cents. Simple payback for this building was only 6 months.

In most cases, it is much easier to accurately track and quantify commissioning costs than it is to track and quantify benefits. Energy savings, for example, are usually determined by In addition to energy savings, the benefits of retrocommissioning include extended equipment life, improved indoor air quality, and reduced $O \& M$ costs. calculation rather than actual measurement. Benefits such as extended equipment life, improved indoor air quality, improved worker productivity, and reduced O\&M costs should not be overlooked, even though they are more difficult to quantify than energy savings. These non-energy. benefits are often more important to building owners and upper management than the energy cost savings. For owners concerned about indoor air quality (IAQ) litigation, improving indoor air quality and documenting the effort may be a primary goal of retrocommissioning. An Occupational Safety and Health Administration (OSHA) report noted that $20-30 \%$ of commercial buildings suffer from IAO problems that are not associated with temperature alone.

Although little research has been completed to document the link between comfort and productivity, common sense tells us that comfortable employees are more productive. The few studies that have been conducted on this topic agree. One estimate of productivity losses in a typical office building where occupants complained of discomfort was stated in the following terms: ${ }^{2}$
Payroll costs
$\$ 150 / \mathrm{ft}^{2} /$ year
Productivity lost to complaint time
$\$ 0.10 / \mathrm{ft}^{2} /$ year

\footnotetext{
${ }^{2}$ Presentation to National Electric Light and Power Association, 1989, by Cedric Trueman, Sr., technical advisor for British Columbia Buildings Corp.
} 
This example assumes that this typical building has one occupant per $200 \mathrm{ft}^{2}$ of space and an annual payroll cost of $\$ 30,000 /$ person or $\$ 150 / \mathrm{ft}^{2}$ of office space. If one out of every five employees spends only 30 minutes a month compensating for or complaining about the lighting or the temperature or both, the employer loses $\$ 0.10 / \mathrm{ft}^{2}$ in annual productivity. For a $100,000-\mathrm{ft}^{2}$ building, this amounts to $\$ 10,000$ per year. Because uncomfortable employees probably spend more than just half an hour each month addressing building comfort issues, the actual losses may be higher.

If comfort problems are severe enough to make employees ill, business owners can sustain additional productivity losses and increased liability risks. Building operation costs also increase, as operators respond to more complaints.

These problems concern not only building owners who occupy their buildings: they affect owners who rent building space as well. Tenants who are experiencing comfort and productivity problems may not remain tenants for long. Based on the estimated costs shown in Table 5 , losing a tenant in Class $A$ office space can be expensive.

Assuming an average office size of $3,500 \mathrm{ft}^{2}$, rented at $\$ 15 / \mathrm{ft}^{2}$ a year, a typical

Table 5. Cost of losing a tenant

\begin{tabular}{cl}
\hline Five-year lease value & $\$ 262,500$ \\
Rent loss due to vacancy & $\$ 26,250$ \\
Improvements for new tenant & $\$ 52,500-70,000$ \\
Leasing commission & $\$ 13,125$ \\
Total cost of losing tenant & $\$ 91,875-109,375$ \\
\hline
\end{tabular}

Source: ASHRAE presentation by David Zier of Melvin Mark Company. The Melvin Mark Company owns, manages, and develops real estate. Available at www.cbs.state.or.us/ external/ooe/cons/commsave.htm.

five-year lease has a value of $\$ 262,500$. If a tenant leaves, this space will remain vacant an average of 6 months, for a total rent loss of $\$ 26,250$. Improvements and build-outs to satisfy a new tenant usually run $\$ 15-\$ 20 / \mathrm{ft}^{2}$, or $\$ 52,500-\$ 70,000$ in this case. On top of all this, the building owner often pays a leasing commission of $5 \%$ of the 5-year lease value, or $\$ 13,125$. Thus, the total cost of losing one tenant could range from $\$ 91,875$ to $\$ 109,375$, or 35 to $42 \%$ of the 5 -year lease value. If a building develops a reputation for being uncomfortable and unproductive, the vacancy period could last longer. Word of uncomfortable building conditions is likely to spread among business peers; market research shows that dissatisfied customers-in this case, tenants-are likely to complain to 7 to 10 of their peers. 


\section{$4 \quad$ Preparing for a Retrocommissioning Project}

T

his section addresses key questions and activities to consider when preparing for a retrocommissioning project. Before starting a such a project, it is helpful to answer the following questions:

- Is retrocommissioning appropriate?

- What resources are available?

- Who needs to be convinced of its value?

Answering these questions help ensure that the benefits of retrocommissioning will meet the needs of both management and O\&M staff.

\section{Is Retrocommissioning Appropriate?}

To some extent, it is easier to answer this question by understanding when retrocommissioning is not appropriate. Generally, retrocommissioning is not appropriate for buildings where

- most of the equipment and systems are either outdated or at the end of their life;

- major system design problems exist; and/or

- major equipment malfunctions exist such that the best remedy is an equipment replacement.

The main intent of retrocommissioning is to improve and optimize how building systems are operated. It is not a method for keeping old, inefficient equipment limping along. Although retrocommissioning should not be performed in lieu of making needed capital improvements, budgets do not always allow for buying new equipment unless existing equipment is broken beyond repair. Under these circumstances, it may be 
better to invest in the retrocommissioning process than continue "firefighting" or doing nothing. This is particularly true for control systems, which sometimes become outdated but are not necessarily broken.

Retrocommissioning may be a costeffective solution to making the best use of the old system and ensuring that any needed equipment repairs or improvements are prioritized on the basis of return on investment.

When considering retrocommissioning, evaluate the equipment and the building systems to determine how many of them will need replacing within the next year or two. Investing in retrocommissioning when the equipment or systems involved will be replaced shortly after the process is completed is obviously not a good investment. However, for buildings with newer equipment (less than 12 years old), retrocommissioning may be the most appropriate first step for optimizing building performance and obtaining cost savings. Energy and facility managers are beginning to see retrocommissioning as an energy efficiency measure in itself, much like any other energy-efficiency retrofit. Owners can use retrocommissioning to obtain low-cost energy saving opportunities before considering more expensive capital improvements. In some cases, the savings from retrocommissioning may help pay for needed capital improvements.

\section{Is an ESPC Being Considered?}

Some level of retrocommissioning is usually appropriate if you are considering any type of energy savings agreement such as an energy savings performance contract (ESPC). There are two primary reasons for performing retrocommissioning before obtaining an energy-savings agreement. First, the low-cost energy savings gained from retrocommissioning remains with the building (the owner gets all of the savings) and does not become part of the financial agreement; second, retrocommissioning optimizes the existing equipment so the most appropriate capital measures are selected and financed through the agreement.

A good reason for doing retrocommissioning as part of an energy-savings agreement is to ensure that the performance of new equipment is not hindered because it interfaces with older equipment, components, or systems that are malfunctioning. Even when commissioning is specified for the new equipment, it often stops short of looking at the systems with which the new equipment interfaces or examining how it integrates with other systems or equipment that may affect its performance. This is especially true for energy management control systems. Because controls are an area where many difficulties and misunderstandings occur between building owners and performance contractors, it is a good idea to specify commissioning for both the new 
equipment and the existing equipment that may affect the performance of the new equipment.

When retrocommissioning is performed before the energy savings agreement or ESPC is finalized, it is important to inform the contractor about the retrocommissioning activities and give him or her a copy of the final report. If the contractor is not informed and energy bills from prior years are used to help determine the energy baseline, the baseline may be inaccurate. This may cause the cost savings upon which the financing is based to be significantly less than expected, leading to disagreements and even legal battles.

Retrocommissioning performed up front to capture the low cost savings may not be a wise choice if the savings from the retrocommissioning do not remain with the building but, instead, go into a general fund. In this case, the "low-cost/no-cost" improvements should be part of the performance contract. In this way, a portion of the savings stays with the building as part of the financial arrangement. Integrating the retrocommissioning measures into the energy savings agreement is a way to capture the savings as part of the investment repayment. The amount invested can be increased when the savings estimates are higher. Moreover, the savings gained from bundling these measures with the capital upgrades-especially if some of the upgrades are marginally cost-effective (i.e., good value but with long paybacks)-help to increase the overall viability and attractiveness of the ESPC funding.

\section{What Resources Are Available?}

Before beginning a commissioning project, it is important to understand what resources are available for getting the work accomplished. The most costeffective projects usually have a least one in-house staff person assigned to the project. The staff person chosen should have expertise in the building's control systems, HVAC equipment, and lighting systems. It is preferable to assign a building operator who knows the building's history and why and how systems are operated and maintained. If the commissioning provider lacks in-house support, the project may still be successful but not always as costeffective as it could be. Another benefit of allowing in-house staff to work on the project is the training they receive. Participating in the project allows them to incorporate many of the troubleshooting and testing methods learned during retrocommissioning into the facility's O\&M program.

When taking stock of the available resources, include calls to the local utility as well as state and local governments (Department of Environmental Quality or the State Energy Office) to find out if they-have-any-services-or-funding-available-for-theretrocommissioning of existing buildings. These organizations may even offer such 
services directly or may have a list of qualified commissioning providers. Also, the utility may be interested in providing metering or monitoring tools for the measuring and diagnostics as part of the retrocommissioning process.

\section{Who Needs to Be Convinced?}

In order to implement a retrocommissioning program or project, obtaining buy-in from those who will be directly involved with the project work, as well as those in upper management who will reap the benefits, is usually necessary.

\section{Obtaining upper management support}

Upper management usually needs to be sold on the financial benefits of the project-managers will want to know how commissioning an existing buildings will positively affect the organization's "bottom

Managers will want to know how commissioning an existing building will positively affect the organization's "bottom line."

line." It may be necessary to provide individuals in upper management, such as the chief financial officer, with a written project proposal to obtain needed financial support. It is important to understand the organization's financial process and philosophy in order to demonstrate how the project can best fit into the budget and why it is important for the company to fund the project. Because retrocommissioning does not generally require capital expenditures, funding can often come from the facility's operating budget. However, this may entail requesting a one-time increase in the budget to cover the project costs.

In making the case for a retrocommissioning project, here are some important ideas to consider:

- Retrocommissioning as an asset management activity. This can be the initial step that helps change the old paradigm of $O \& M$ as part of the "cost of doing business" to a new paradigm of $O \& M$ as part of sound asset management. Retrocommissioning increases the ability of the $O \& M$ department to provide quality services to its clients. Also, the facility's net operating income increases when a building is operated as energy efficiently as possible.'

- Retrocommissioning as a risk-reduction method. Reducing the risk of tenant loss, early equipment failure, IAO issues, and high utility bills also increases the asset value of the facility.

1 M. Chao and D. Goldstein, Energy Efficiency and Property Valuation by Appraisers and Financial Markets: The Need for Commissioning and Credible Performance Documentation (San Francisco: Institute for Market Transformation, September 1997, 1-6). 
- Retrocommissioning as an internal benchmarking technique. The documentation and testing completed during the commissioning process can be used to set the internal benchmarks for building operating performance, including indoor environmental quality. This sets the pace for providing an ongoing record of quality control and increases the quality focus for the facility.

- Retrocommissioning as part of the energy management program. Retrocommissioning supports the efficient operation of the energy-using equipment in the building. This is a low-cost method for obtaining savings without capital outlay. The savings obtained may help offset the cost of needed capital improvements.

Both the energy and non-energy benefits of the proposed project must be presented clearly. Measurable objectives will aid in getting management buy-in. These objectives should be presented to upper management along with a brief description of the intended measurement and verification methods. Chapter 4 discusses this concept in more detail in the planning section entitled "Developing and Communicating Objectives."

Once the case for retrocommissioning has been presented, it is often effective to leave the decision-makers with some brief, clear informational materials. The resource booklet What Can Commissioning Do For Your Building? may help obtain management buy-in to the importance of retrocommissioning as well as commissioning for new equipment. This booklet, which draws from a database of 175 case studies, is geared specifically toward upper management in that it is short (13 pages) and clear about the energy and non-energy benefits of commissioning. Information about obtaining copies of this booklet can be found at the end of Appendix A.

\section{Obtaining building operating staff support}

The building operating staff also need to feel committed to the retrocommissioning effort. They need to view retrocommissioning as part of the overall O\&M program that positively supports their work and not as a fault-finding, make-work exercise. Staff support can be gained by including $O \& M$ personnel in defining the results they want from the project. For example, building staff should be better trained, less taxed with nuisance problems and trouble calls, and more able to proactively pursue preventive $O \& M$ tasks, leading to better use of their time. Bringing in an outside commissioning provider can sometimes be threatening. Therefore, it is important that the building staff be assured that the commissioning process will actively address their needs and help them provide better service. 
T

his section introduces and discusses some strategies for selecting successful projects, increasing the cost-effectiveness of the projects, and determining the roles and responsibilities of the major participants. Desirable characteristics that help improve retrocommissioning value are listed in Table 6.

Table 6. Characteristics that improve retrocommissioning value

- Management support and commitment

- A motivated and available building staff

- An unjustified, high-energy-use index

- An energy management control system (EMCS)

- No major system problems

- Easily accessible and up-to-date building documentation

- Newer equipment (12 years old or less)

- Cooperative tenants or occupants

\section{Selecting the Right Project}

Some buildings or groups of buildings make better candidates for retrocommissioning than others. Owners of multiple buildings may want to develop a spreadsheet to better understand and compare their building stock, and then prioritize retrocommissioning projects according to which sites present the most opportunity for obtaining cost-effective $O \& M$ improvements. Buildings that appear to be the best or most attractive candidates (that exhibit the most opportunity for improvement) should be first in line for retrocommissioning. The most broken buildings may not be the most attractive, while fairly new buildings may offer the most savings or benefit for the least cost. Appendix $B$ includes a list of building characteristics that may be placed in a database or spreadsheet format for comparing multiple buildings.

The following discussion provides some guidance on characteristics desirable in buildings to be retrocommissioned. Not all of the elements discussed below need to be present for the project to be successful, but the more elements that are present, the better the chance for success. 


\section{Energy management control systems}

Buildings with computerized energy management control systems (EMCSs) often make some of the best candidates for retrocommissioning. A recent survey of class $A$ and $B$ building owners showed that although a high percentage of the buildings surveyed had computerized control systems, the systems were underutilized. The systems were capable of performing more sophisticated energy management strategies than they were actually set up to do. This

The best building candidate for retrocommissioning will have

- an EMCS

- no major system problems

- an in-house O\&M staff

- building documentation

- newer equipment

- cooperative tenants situation generally offers energy-saving opportunities. Other saving opportunities stem from the fact that EMCSs, no matter how recently they were installed, are often just not functioning correctly. Most were never commissioned at installation. In addition, unless building staff members have received adequate training, they are often unaware of how to program and troubleshoot the EMCS and how to use it as a powerful tool for diagnosing the performance of HVAC and other systems. Many of these systems lack adequate documentation, such as written sequences of operation or control strategies, making it difficult for building staff to understand what the EMCS was intended to do. Not only can retrocommissioning provide a fully optimized system, but it also can document exactly what control sequences and strategies are presently incorporated into the system. The process can also provide important training for building staff.

\section{Absence of major system problems}

Buildings with known major system problems, especially design problems, are generally not good candidates for retrocommissioning because the solutions are more complex than typical retrocommissioning alone can provide. Also, buildings that have not been through an asbestos abatement process may be subject to stringent requirements for working in the building that can drive the cost of a project beyond what is acceptable. Because the cost-effectiveness of a retrocommissioning project is primarily connected with optimizing how a building is operated, buildings with broken control systems generally do not make good candidates. For example, buildings with pneumatic control systems that have oil or water throughout the pneumatic lines, or buildings where the EMCS is out of date, cannot be upgraded, or lacks documentation, would typically be considered as having a broken control system. Repairing major problems is a must before retrocommissioning.

\section{In-house O\&M staff}

Retrocommissioning performed on buildings with experienced, willing, and available building-staff is-more-likely-to-be-cost-effective-and-have-lasting-results. Staffknowledge, especially in the area of controls, can minimize costs. Staff can perform 
many of the tests and implement many of the improvements without having to hire outside contractors. They can also readily provide the commissioning provider with accurate information about the building's operating strategies and maintenance procedures.

\section{Accessible and up-to-date building documentation}

The condition of building documentation is another important criterion in selecting a building for retrocommissioning. Having the commissioning provider spend numerous hours recreating and gathering critical building documentation can increase the cost of the project significantly. Unless updating building documentation is a primary objective for the retrocommissioning project, owners should choose buildings with complete and up-to-date documentation if they want to increase the cost-effectiveness of the project.

\section{Newer equipment.}

Equipment age can also have a significant impact on the project. If most of the building's primary energy-using systems are at the end of their lives (especially if they have not been well-maintained), retrocommissioning is probably not the best choice for obtaining energy savings or reducing risk. Buildings containing equipment that is no more than 12 years old are usually better candidates for retrocommissioning.

If improvement strategies can be implemented and produce the desired return on investment (ROI) in less time than the remaining life of the equipment, it makes sense to implement them. Properly planned control improvements, such as those invoked by an EMCS, can be applied to existing equipment for its remaining life and then applied to new equipment as replacements occur.

If significant equipment or EMCS upgrades or replacements are already scheduled to occur within the next two years, the owner should consider combining retrocommissioning of the existing equipment and the new installations at that time.

\section{Cooperative building tenants}

Buildings with tenants who are unwilling to cooperate with the retrocommissioning process or who use areas in the building that are particularly sensitive to any operational changes may not be good candidates for retrocommissioning, especially if these tenants occupy most of the building space. On the other hand, if the building houses tenants who have numerous complaints about comfort or environmental quality, the building may be a very good candidate for retrocommissioning. 


\section{Energy Accounting}

Whether or not a project involves an energy-efficiency retrofit, obtaining energy-use data on the buildings being considered for retrocommissioning is fundamental for selecting a successful project. Buildings with excessive energy use or energy budgets are usually good candidates as long as the reason for their high energy use is not easily justified. High energy use is often justified for buildings with high occupant densities, 24-hour-per-day operation, high outdoor air requirements, or sizable computer facilities.

The building annual energy use index (EUI) is the common benchmark used to make building energy use comparisons. ${ }^{1}$ It is expressed in energy use per square foot of floor area $\left(\mathrm{Btu} / \mathrm{ft}^{2}\right.$ or $\mathrm{kWh} / \mathrm{ft}^{2}$ ). This normalizes for floor area, allowing buildings of different sizes and similar use to be compared. It is best to compare a building with others in the same city or region so that major climatic differences do not affect the EUIs. A higherthan-normal EUI can indicate significant opportunities for retrocommissioning. A lower EUI, however, does not necessarily mean a lack of opportunities.

An example of EUls for various types of commercial buildings is provided in Table 7. These EUls are based on a sample of over 6,000 buildings across the United States. They are disaggregated into low, medium, and high categories corresponding to the 25th, 50th, and 75th percentiles when all buildings in the sample are ordered by ascending EUI. ${ }^{2}$ At the 75 th percentile, $75 \%$ of all U.S. buildings would be more efficient. While these EUls are accurate indicators for buildings nationwide, they are not necessarily good benchmarks for a building in a specific location (because all U.S. climates are represented in the table). EUls based on this same sample and broken out into nine U.S. regional locations can be found online at Oak Ridge National Laboratory's (ORNL's) Buildings Technology Center web site. ${ }^{3}$ These are better EUI benchmarks for individual buildings because their regional basis accounts for most of the nationwide variations in climate and fuel types.

'The annual energy use index (EUI), also known as a building annual energy budget, is generally calculated in Btus per square foot of gross floor area. All fuels are taken into consideration by converting them to Btus for the calculation. The total Btus for the year are then divided by the building gross square footage.

${ }^{2}$ Research at Oak Ridge National Laboratory has found that comparing an individual building to a distribution of building EUls is a better performance indicator than comparison to average EUls (T. R. Sharp, "Energy Benchmarking in Commercial Office Buildings," pp. 321-29 in Proceedings of the ACEEE 1996 Summer Study on Energy Efficiency in Buildings, vol. 4, Pacific Grove, Calif., August 23-28, 1996).

${ }^{3}$ All of the web sites referred to in this chapter can be found in Appendix A. 
Table 7. Distribution of annual total energy use intensities (EU/s) for commercial buildings

\begin{tabular}{|c|c|c|c|c|}
\hline \multirow{2}{*}{ Commercial building type } & \multirow{2}{*}{$\begin{array}{l}\text { Number of } \\
\text { buildings in } \\
\text { sample }\end{array}$} & \multicolumn{3}{|c|}{ Annual total energy consumption $\left(\mathrm{kBtu} / \mathrm{ft}^{2}\right)^{a}$} \\
\hline & & Low & Medium & High \\
\hline Office & 1383 & 79 & 135 & 228 \\
\hline Mercantile and service & 1206 & 56 & 106 & 198 \\
\hline Warehouse (non-refrigerated) & 912 & 18 & 42 & 95 \\
\hline Education & 718 & 76 & 113 & 160 \\
\hline Public assembly & 380 & 39 & 82 & 149 \\
\hline Religious worship & 372 & 26 & 47 & 74 \\
\hline Vacant & 263 & 8 & 29 & 82 \\
\hline Lodging & 255 & 100 & 184 & 325 \\
\hline Food service & 232 & 219 & 441 & 766 \\
\hline Health care (inpatient) & 126 & 109 & 164 & 364 \\
\hline Parking garage & 106 & 59 & 125 & 169 \\
\hline Food sales & 103 & 248 & 418 & 686 \\
\hline Public order and safety & 83 & 93 & 145 & 225 \\
\hline Laboratory & 68 & 82 & 254 & 545 \\
\hline Health care (outpatient) & 63 & 80 & 144 & 236 \\
\hline Skilled nursing & 48 & 143 & 254 & 321 \\
\hline Warehouse (refrigerated) & 39 & 56 & 102 & 188 \\
\hline
\end{tabular}

Source: Energy Information Administration (EIA), Commercial Buildings Energy Consumption and Expenditures, DOE/EIA-0318(92) (Washington, D.C.: EIA, 1995).

a Low, medium, and high categories correspond to 25 th, 50th, and 75 th percentiles of the sample, respectively. To calculate your annual total energy use for comparison to values in this table, these approximate conversion factors can be used:

fuel oil $=140 \mathrm{kBtu} / \mathrm{gal}$;

natural gas $=100 \mathrm{kBtu} / \mathrm{ccf}, 100 \mathrm{kBtu} / \mathrm{therm}$, or $1000 \mathrm{kBtu} / \mathrm{mcf}$;

electricity $=10.3 \mathrm{kBtu} / \mathrm{kWh}$.

A site-based electricity conversion factor $(3.412 \mathrm{kBtu} / \mathrm{kWh})$ should not be used. If used, EUI distributions for electrically dominated buildings, particularly all-electric buildings, are considerably different from those represented by this table. 
There are a few software tools that allow the user to compensate for additional secondary effects when comparing buildings based on EUIs. One of these is MAISY, a commercial software product that provides the user access to U.S. Department of Energy (DOE) national building databases; product information is available at the Jackson Associates web site (see Appendix A). By specifying some of your building characteristics, you can examine the energy use data of U.S. buildings with the same characteristics. Statistical analysis of these can then be done to determine the impacts of the different building characteristics.

ORNL has developed an easy-to-use, spreadsheet-based benchmarking tool for office buildings that uses simple distributional ranking and compensates for the most important secondary drivers of office building energy use. ${ }^{4}$ This tool requires between five and eight inputs-such as building location,. size, energy use, and number of workers-for its ranking. The tool calculates EUls for the user's building, calculates the typical EUI of buildings with the same characteristics, and then ranks the building in comparison to others. This tool can be downloaded from ORNL's Buildings Technology Center web site. A similar tool is under development for public schools.

The joint Environmental Protection Agency (EPA)/DOE Energy Star Label for Buildings Initiative has just completed a benchmarking tool for online use. The tool provides an indicator for comparing office building energy performance, also normalized for secondary drivers, and can be found at the Energy Star Building Label home page.

\section{Increasing Cost-Effectiveness}

Thorough preparation and participation by building staff prior to and throughout the project reduces overall costs. By employing five strategies, in-house building staff can streamline the project and increase the effectiveness of the commissioning provider's time:

1. gather building documentation;

2. perform appropriate preventive maintenance;

3. perform simple repairs and improvements as the project progresses;

4. perform diagnostic monitoring and functional testing; and

5. implement selected improvements and repairs.

These strategies should be planned as appropriate and introduced to the building staff before putting the retrocommissioning process into action. If the project, due to

\footnotetext{
${ }^{4}$ Sharp, "Energy Benchmarking."
} 
size or complexity of the project dictates, using a bid process for obtaining commissioning services, the request for proposals should state which of the tasks discussed below are in-house building staff responsibilities. This helps the bidders understand what to expect from the owner's staff and develop their budgets accordingly.

\section{Gather building documentation}

Compile an up-to-date building documentation package prior to the retrocommissioning process. If this is not done ahead of time, the commissioning provider will need to gather this information. This packet should be available on-site and contain as much information as possible, including

- drawings relevant to the systems targeted for commissioning (preferably "as-built" drawings if accurate);

- O\&M manuals;

- testing, adjusting and balancing (TAB) reports;

- original design documentation;

- an equipment list with nameplate information, dates of installation, and submittals, including pump curves and fan curves;

- a list of outside service contractors regularly used;

- copies of current service contracts;

- control system documentation, such as sequences of operation, special control strategies, control diagrams, points list, and control program or code;

- energy-efficient operating strategies;

- energy bill (electric, gas, steam, chilled water, etc.) or energy accounting information for at least the last 24 months, along with a rate schedule, unit price, or supply contract information for each energy type; and

- water and sewer usage and billings.

It is possible that some of the information, such as pump curves, fan curves, and written sequences of operation, will not be readily available. However, the more documentation that in-house staff can update and compile, the less time the commissioning provider will.spend obtaining this information. Performance curves are generally available from the original installing contractor or the equipment manufacturer. Have the nameplate information, including the serial number and date of 
installation, available when contacting either of these parties. Appendix $\mathrm{C}$ contains a typical checklist of documentation required as part of retrocommissioning.

\section{Perform appropriate preventive maintenance}

Special care should be taken to make sure that all in-house staff or an outside maintenance service contractor completes scheduled preventive maintenance work before retrocommissioning begins. For example, if retrocommissioning occurs during the cooling season, the annual preventive maintenance tasks for the cooling plant and systems should be completed before commencing with the project. It is not costeffective to hold up the retrocommissioning process because of dirty filters, loose belts, broken dampers, or loose electrical connections. The commissioning provider's time is better used helping the building staff find and solve operating, design, and installation problems rather than addressing equipment-care deficiencies.

\section{Perform simple repairs and improvements as the project progresses}

Depending on the skill level of the building staff, staff can perform a number of improvements and repairs as the project progresses. Completing simple repairs and adjustments discovered during the early part of the investigation phase increases the effectiveness of the diagnostic monitoring and testing. For example, there is no reason to wait to calibrate or relocate a sensor or fix a binding damper only to have the diagnostic and testing phase of the project indicate, once again, that this is a problem. Also, finding an effective solution to a problem is often accomplished through a series of "fixes" occurring over the course of the project. Often, correcting what appears to be a simple problem may allow the diagnostics testing to uncover a larger but subtle problem which can then be taken care of. These "simple fixes," no matter how minor they appear, should be logged on the Master List of deficiencies and potential improvements. (This list is discussed in more detail in Chapter 7 , in the section entitled "Investigation Phase.")

Note that if energy and/or energy-related cost savings are retrocommissioning objectives, it may be important to ensure that energy and cost baselines are well established prior to performing any significant repairs or improvements.

\section{Perform diagnostic monitoring and functional tests}

It is often appropriate and cost-effective to have the most motivated and interested building staff assist with the short-term diagnostic monitoring, trend-logging, and functional testing that occurs during the investigation phase of the project. This helps reduce project costs and provides the building staff with a learning experience that they can reapply later. If building staff are trained to initiate trend logs using the building's 
EMCS, a commissioning provider can reduce time spent on the task and the owner will not need to hire a controls contractor to do the trending. Building staff may also assist with the installation and removal of portable data loggers used for short-term diagnostics and assist with carrying out functional test plans. This also reduces costs and gives the building staff exposure to different approaches to troubleshooting problems and investigating and verifying equipment performance.

\section{Implement selected improvements and repairs}

Depending on availability and expertise, O\&M staff may be enlisted to implement the selected repairs and improvements. Using in-house staff to perform these tasks reduces costs. Hiring an outside contractor to implement major repairs and improvements may cause the payback to increase to the point where the project is no longer cost-effective. The success of this cost-reducing strategy hinges on in-house staff training, knowledge, and willingness to carry out the work. Existing workloads of O\&M staff should be analyzed to determine how schedules and workloads will be shifted to accommodate any additional work. 


\section{$6 \quad$ Roles and Responsibilities of Project Team Members}

$\mathrm{R}$ retrocommissioning team may simply consist of the commissioning provider and a designated member of the operating staff. If the project is fairly complex and the commissioning scope is broad and inclusive, the team could include all or a combination of the following:

- owner or owner's representative (project manager, facility manager, or property manager);

- commissioning provider;

- one or more building operators;

- test specialists;

- a design engineer;

- installing contractors, controls and maintenance service contractors, etc.;

- manufacturer's representative(s); and

- utility representative(s).

Budget considerations and the characteristics of the project may dictate the number of team members and their responsibilities. For cost-effectiveness the retrocommissioning team should be streamlined to fit the complexity of the project. Owners should consult with their

For cost-effectiveness the retrocommissioning team should be streamlined to fit the complexity of the project. Owners should consult with their commissioning provider about the makeup of the team. commissioning provider about the makeup of the team. The commissioning provider can review the scope of work and advise the owner on how to consolidate roles and tasks to best meet the needs of the project. The roles and responsibilities of potential team members are discussed below, with emphasis placed on the roles of the owner, commissioning provider, and building operators. 


\section{Building Owner or Owner's Representative}

The most significant role of the building owner or owner's representative is to support the commissioning provider's efforts to accomplish the work. Other responsibilities may include

- determining the project's budget, schedule, and operating requirements;

- determining the objectives and focus of the project and communicating them to the team members;

- hiring the commissioning provider and other members of the project team;

- assigning appropriate in-house staff to the project;

- defining the building protocols (see the section entitled "Planning Phase" in Chapter 7);

- defining the lines of communication between the team members;

- working with the commissioning provider to determine the commissioning plan and how to best leverage existing resources to streamline the project and reduce costs;

- supporting the commissioning provider by facilitating communication between the commissioning provider and other project team members as needed;

- informing the building occupants of the intended retrocommissioning work as needed;

- requiring and reviewing progress reports and meeting notes; and

- attending training sessions and commissioning meetings when appropriate.

\section{Commissioning Provider}

The commissioning provider's tasks and responsibilities depend on the scope of the project, the budget, and the skill of the building O\&M staff. The following three lists outline the commissioning provider's responsibilities for a typical retrocommissioning project and for a retrofit project and present additional, but less typical, responsibilities for consideration.

\section{Typical retrocommissioning responsibilities}

- Identify what documentation, drawings, data, and other information will be required. 
- Develop a building-specific commissioning plan.

- Develop agendas and facilitate all commissioning meetings.

- Submit required progress reports and commissioning meeting notes to the project and facility manager according to the schedule.

- Perform a detailed on-site assessment of the present maintenance practices and operating strategies, noting all possible deficiencies and improvements.

- Understand the warranties and service contracts that are in place and how they can be leveraged on behalf of the project.

- Develop monitoring and testing plans.

- Perform short-term diagnostic monitoring, using EMCS trend-logging where appropriate.

- Develop, oversee, and document functional test procedures as needed.

- Develop Master Lists of deficiencies and improvements.

- Recommend system or energy-efficient capital improvements for further investigation.

- Prioritize the most cost-effective improvements for implementation for existing systems.

- Supervise the implementation of the selected improvements.

- Perform post-installation monitoring and testing activities as needed.

- Calculate the estimated energy savings based on the before-and-after short-term energy measurements.

- Submit a final report and all specified deliverables.

\section{Typical retrofit project responsibilities}

When the commissioning of new equipment is integrated with the commissioning of existing equipment, as in the case of an energy retrofit project, the commissioning provider's responsibilities may expand to include the following tasks related to commissioning the retrofit project: 
- Develop commissioning specifications for the new equipment.

- Develop a commissioning plan specifically addressing the new equipment.

- Oversee the commissioning of the retrofit project, including the delivery of specified staff training and system documentation.

- Perform short-term diagnostic monitoring of existing systems and the new equipment to ensure that they are properly integrated.

- Develop and oversee prefunctional checklists and manual functional test procedures as needed on the new equipment.

- Develop separate Master Lists of deficiencies for the new equipment.

- Ensure that the identified deficiencies for the new equipment are resolved to the owner's satisfaction.

\section{Additional responsibilities for consideration}

A commissioning provider may be asked to fulfill some less typical responsibilities as part of commissioning an existing facility:

- Finalize an O\&M plan for the facility, including guidelines for implementing a new preventive maintenance plan.

- Review the present service contracts and make recommendations for improvements.

- Develop complete written sets of sequences of operation for all equipment and systems.

- Develop an energy management plan including strategies for obtaining upper management buy-in.

- Develop a comprehensive training plan for O\&M staff. This task may encompass developing recommendations for appropriate building staff to attend training in fundamental O\&M concepts as well as more sophisticated methods for specific equipment and systems. The audience could include building operators, property managers, facility managers, and owners.

- Develop guidelines and recommendations for incorporating an energy accounting system into the energy management or facility management program.

- Develop, start up, and train staff to use the energy accounting system.

- If a new EMCS is being considered, develop a list of functional requirements and energy- efficient operating ${ }^{-}$strategies to be-included in the-new system. 
- Develop methods for the owner and building staff to continue to track the performance of the improvements.

- Develop a guideline for including commissioning and retrocommissioning as part of the organization-wide energy management plan.

\section{Building Operators}

Assigning building operators to assist with (or at least observe) as much of the retrocommissioning as possible improves their understanding of the equipment and control strategies. It also trains them to be able to retest or recommission systems periodically as part of their ongoing $O \& M$ program. The following list includes tasks that building operators are typically responsible for depending on their skill level:

- gathering and updating building documentation;

- providing detailed input into the initial assessment and investigation process;

- performing appropriate preventive maintenance and commissioning-generated checklist tasks prior to any diagnostic or functional testing;

- installing and removing short-term diagnostic monitoring equipment;

- gathering trending information from the EMCS as required;

- assisting with the performance of manual functional testing as needed; and

- attending project meetings and training as required.

\section{Design Professionals}

Depending on the age of the equipment and systems involved, and on whether a new installation is occurring during the retrocommissioning process, design professionals may or may not be involved in the project. Design professionals are rarely involved in a pure retrocommissioning process unless the commissioning provider needs additional expertise regarding design issues that are uncovered during the investigation process. In such cases, the design engineer (perhaps the engineer who designed the original installation) may be brought on the team as a consultant to help resolve the issues. When commissioning a new installation is part of the project, the designer responsible for the new equipment and system should be part of the commissioning effort. 


\section{Contractors and Manufacturer Representatives}

Installing contractors, maintenance service contractors, controls contractors, and manufacturer representatives can be important contributors to the commissioning of existing equipment, especially when equipment is relatively new, still under warranty, or under contract for service by a manufacturer's representative or a particular service contractor. In some cases, one firm may have installed the system as a manufacturer's representative and also hold the service contract for the system. This is often true for control systems and large plant equipment such as chillers and boilers.

If equipment is still under warranty or under a service contract, it is important that the responsible company or individual be brought on the team early in the process. Contractors or manufacturers are primarily responsible for performing the hands-on testing of the system that they have installed or serviced, especially if a warranty will be void if anyone else manipulates the equipment. They may also be responsible for correcting any deficiencies that are found during the retrocommissioning process. Compensation for these parties depends on the extent of the service contract or warranty coverage.

Some owners do not have full or even part-time building operators, or may have building operators with minimal skills or time. These owners often use service contracts to cover most of their HVAC, controls, and electrical systems. In such cases, the service contractor may take on retrocommissioning tasks that building operators would usually perform. The contractor may be requested to perform certain scheduled preventive maintenance tasks to coincide with the needs of the commissioning project, as well as assist in performing the hands-on testing, diagnostics, and adjusting and calibrating of equipment. Controls contractors may contribute by assisting with trend logs and EMCS programming tasks.

The controls contractor may be a key player on the commissioning team because he or she is often the most familiar with the building's control sequences and programming. The control technician's expertise can expedite the incorporation and testing of new or improved control strategies for the building. Although enlisting the time of a control technician may be expensive, limiting their assistance can reduce the overall cost-effectiveness of the project.

\section{Testing Specialists}

Depending on the needs of the project, testing specialists may need to join the retrocommissioning team. Special equipment such as variable-volume fume hoods may require special testing expertise. Although the commissioning provider typically writes the test procedures, the testing may be carried out by others who are experts in their field. Testing, adjusting, and balancing (TAB) professionals may be asked to verify water or air flows using special equipment if the retrocommissioning identifies possible air or water balance problems. While some commissioning providers are also test 
engineers and are fully tooled to perform almost any type of test required, this is not usually the case. Most commissioning providers are skilled at performing fundamental HVAC functional tests and calibration exercises, but rely on other professionals or test experts for more complicated testing. Appendix $D$ contains a typical list of commissioning tools.

\section{Utility or Government Representative}

The role of utility or state and local government representatives in the project is generally limited to assisting with specific items that the customer needs in a timely manner. This assistance might include loaning equipment and providing billing data, technical expertise, or funding. If utility or government representatives are providing funding or a service as part of the project, they may want to be involved in meetings or receive periodic progress reports. 


\section{$7 \quad$ Retrocommissioning in Action}

nce the facility manager has obtained the necessary support and funding for the retrocommissioning project, work can begin. The retrocommissioning process can be viewed as consisting of four primary phases:

1. planning,

2. investigation,

3. implementation, and

4. handoff.

Figure 1 is a flow chart presenting these phases, along with the process steps in each. Table 8 summarizes the primary activities and products of each phase. All of the four phases and their related steps are discussed in more detail below.

In reality, the phases and many of the steps overlap and may occur simultaneously; some may be eliminated, depending on the nature of the project. Depending on the budget, in-house expertise and availability, and the scope of the project, the planning phase may be partially if not entirely completed by the owner or the building staff. Of the four phases discussed below, the planning phase is discussed in the most detail because it involves the most input from management. When project planning is well thought out, success generally follows.

The possible deliverables are listed at the end of each phase discussed in this section. However, many of these are not fully completed until the hand-off phase, when they are included in the final project report.

\section{Planning Phase}

\section{Developing and communicating the objectives}

The retrocommissioning process begins by defining in writing the exact objectives for the project and clearly communicating those objectives to the team involved in carrying out the work. Often the main objective for commissioning an existing facility is to obtain cost savings from improving the operation of the building's energy-using 


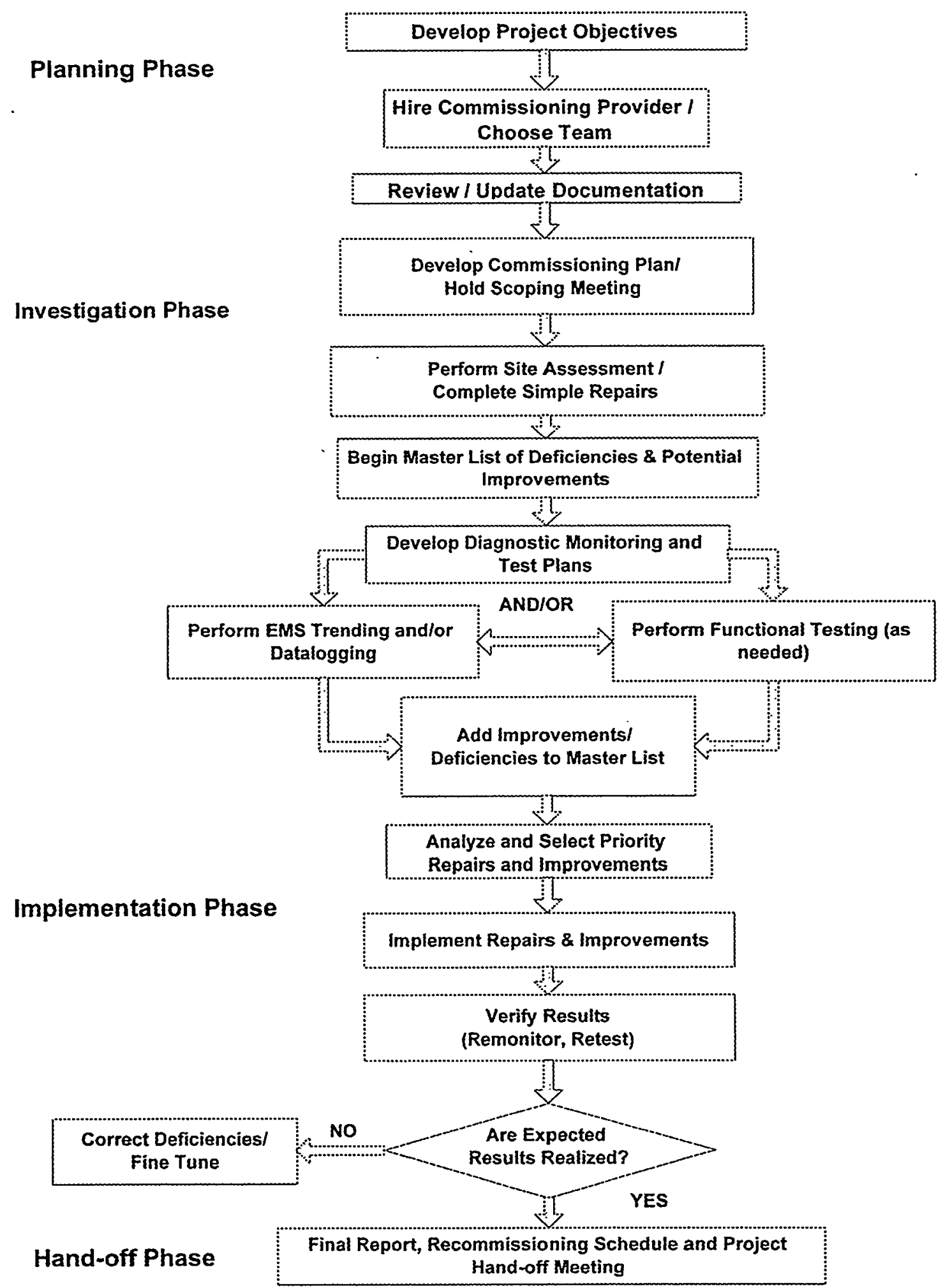

Fig. 1. The phases and activities of the retrocommissioning process. 
Table 8. Summary of retrocommissioning activities and products

\begin{tabular}{|c|c|c|}
\hline Phase & Activities & Primary products/deliverables ${ }^{a}$ \\
\hline Planning & $\begin{array}{l}\text { 1. Developing and communicating } \\
\text { objectives } \\
\text { 2. Choosing team and hiring } \\
\text { commissioning provider } \\
\text { 3. Reviewing and updating building } \\
\text { documentation and historical } \\
\text { utility data } \\
\text { 4. Developing retrocommissioning } \\
\text { project plan and holding scoping } \\
\text { meeting }\end{array}$ & $\begin{array}{l}\text { - Retrocommissioning project plan } \\
\text { (including project objectives and } \\
\text { scope) } \\
\text { - Scoping meeting minutes }\end{array}$ \\
\hline Investigation & $\begin{array}{l}\text { 1. Performing site assessment } \\
\text { 2. Developing Master List of } \\
\text { deficiencies (repairs) and } \\
\text { potential improvements } \\
\text { 3. Developing short-term diagnostic } \\
\text { monitoring plans } \\
\text { 4. Performing functional testing, } \\
\text { diagnostics, and trending } \\
\text { 5. Selecting most cost-effective } \\
\text { opportunities for implementation }\end{array}$ & $\begin{array}{l}\text { - Short-term diagnostic monitoring } \\
\text { and functional test plans } \\
\text { Master List of deficiencies and } \\
\text { potential improvements (known } \\
\text { as the Master List) } \\
\text { - Completed assessment forms } \\
\text { and diagnostic test results } \\
\text { - List of selected improvements } \\
\text { for immediate implementation }\end{array}$ \\
\hline Implementation & $\begin{array}{l}\text { 1. Implementing improvements } \\
\text { 2. Retesting and remonitoring }\end{array}$ & $\begin{array}{l}\text { - Completed repairs and } \\
\text { improvements (noted on } \\
\text { revisions to Master List) } \\
\text { - Final estimated cost and energy } \\
\text { savings calculations for energy } \\
\text { efficiency and cost-saving } \\
\text { improvements }\end{array}$ \\
\hline Handoff & $\begin{array}{l}\text { 1. Completing final report } \\
\text { 2. Maintaining investment by } \\
\text { developing recommissioning } \\
\text { plan, training, and performance } \\
\text { tracking } \\
\text { 3. Holding project closeout meeting }\end{array}$ & $\begin{array}{l}\text { - } \quad \text { Final report } \\
\text { improvemmended capital } \\
\text { investigation for future } \\
\text { - Revised or upgraded building } \\
\text { documentation (if required as } \\
\text { part of project) } \\
\text { Recommissioning plan or } \\
\text { schedule }\end{array}$ \\
\hline
\end{tabular}

${ }^{a}$ All phases should include progress reports and minutes from meetings. 
equipment, given current operating requirements. Identifying and eliminating potential indoor air quality and comfort problems is also often high on the list of retrocommissioning objectives. Figure 2 shows an example of written objectives for a retrocommissioning project in order of priority.

Additional objectives for performing retrocommissioning may include

- reducing comfort complaint calls,

- eliminating targeted indoor environmental quality problems,

- increasing equipment life,

- reducing staff time spent on emergencies and reducing failure rates,

- retaining tenants and solving specific complaints,

- increasing O\&M staff skills and improving procedures,

- updating building documentation,

- preparing existing systems and equipment to interface with a new computerized EMCS, and

- benchmarking the operational status of existing systems and equipment.

Also in this first phase, the project team should begin to consider the measurement and verification (M\&V) methods needed to evaluate the selected objectives. For many projects, retrocommissioning opportunities are evaluated both before and after implementation. Evaluating the estimated cost and benefit of each recommendation before the implementation phase is used to help prioritize which opportunities will yield the most value. Usually, those estimated to cost the least and produce the most savings are implemented first. Following the implementation phase, evaluation is used to verify whether or not the project objectives have been reasonably met. This usually includes comparing the actual costs and calculated savings for energy-efficient improvements with their estimated cost and savings. 
Evaluating results is more easily accomplished and less costly for some objectives than for others. For example, using a simple method such as a written logging system to compare the number of comfort calls occurring before and after the retrocommissioning process is straightforward and inexpensive and can be implemented by in-house staff. On the other hand, understanding the before-and-after energy use or showing indoor air quality improvement are usually more challenging evaluations. ${ }^{1}$

The costs of M\&V must be weighed against the need to verify performance or accomplishments. Owners who are primarily interested in obtaining a building that works well and maintains a

The costs of measurement and verification must be weighed against the need to verify performance or accomplishments.

comfortable environment for their occupants may be less concerned with knowing exactly how much energy savings should be attributed to the retrocommissioning effort. Some of the recommended improvements resulting from the investigation phase of the project may demonstrate such obvious benefits that owners are willing to implement them without performing any complicated energy analysis. Forgoing extensive analysis reduces the cost of the project.

The methods selected for $M \& V$ depend on each objective and the overall project goals. Research and demonstration projects where the major goal is to demonstrate detailed results for particular objectives (such as energy savings or improved indoor air quality) usually require the most rigorous and expensive M\&V methods. If retrocommissioning is performed as part of an energy-savings agreement such as an ESPC, the level of rigor for verifying cost and savings may be significant. What is important to remember for typical retrocommissioning projects, where the owner takes the risk and pays the costs, is that the cost for measuring and verifying results should be closely scrutinized before choosing a method. The cost of a rigorous evaluation method can sometimes equal or exceed the cost of identifying and implementing repairs and improvements. For facility or energy managers who need to feel confident about getting value for their investment and are planning to present results to upper management, less expensive methods are usually appropriate.

Owners and managers can gather information for calculating and verifying energy savings by using whole-building metering, end-use metering, or a combination of the two to obtain a before-and-after comparison of energy use and demand. If there is a desire or requirement for this type of verification rigor, the local utility may be willing to help. Some utilities are interested in obtaining data on energy savings through retrocommissioning and may be willing to install a pulse meter that will provide 15 -minute readings of the whole building's electric use. These readings-in combination with short-term end-use monitoring, which may be accomplished using portable data

\footnotetext{
'Most states have an Industrial Commission, a Department of Occupational Safety and Health, a Department of Environmental Quality, or some other similar organization that will perform air quality sampling and testing at little or no cost. In some states, there are tax incentives offered for air-quality-related capital improvements.
} 
loggers (discussed in more detail in the section "Investigation Phase")- usually provide an adequate amount of information for acceptable calculation of energy and demand savings. Simply comparing before-and-after energy bills is another method that is easier and less expensive but also less accurate. No matter which method is used, it is sometimes difficult to determine what causes an increase or decrease in energy unless variables such as weather, occupancy, utility rate schedules and changes, and building use are taken into consideration. Facilities that have computerized energy accounting systems should consider using them to help evaluate projects focused on obtaining energy savings. Many of these systems are capable of performing weather adjustments to make annual before-and-after comparisons more accurate. This is especially true for buildings that have both a stable occupancy rate and unchanged building use.

\section{Choosing the team and hiring the commissioning provider}

A team will be responsible for achieving the objectives defined for the project. Initially, this team will typically require two teams working together: an owner's team and a contractor team. The teams can be small as long as needed skills and authority. are represented on each. These two teams must join to become the project team. The skills and authority of the owner's team must be adequate to obtain acceptable contractor services and to interface with the contractor team. Without a reasonable balance between teams, the creation of the project team will be difficult or the project team will be flawed (and potentially not able to manage the project adequately).

\section{Choosing the team}

Chapter 6 briefly discusses the roles and responsibilities of all the possible retrocommissioning team members. The important functions of the owner team and the commissioning provider team are clearly evident in that discussion. These two teams must handle many functions, which will drive the ability of the project team to function. Care must be taken that the people assigned to these team positions are able to handle the defined roles and responsibilities.

The owner or owner's representative responsible for the project has the responsibility for bringing the overall team together. The commissioning provider may have varying levels of involvement in this process of bringing the team together, depending on the level of trust and confidence established. The overall team should consist only of those people most critical to accomplishing the work.

For buildings with an in-house staff, one of the most important team members is the building operator assigned to work with the commissioning provider. Ideally, the assigned operator should have historical knowledge of how and why equipment and systems are operated and maintained in the present manner and have a thorough knowledge of the building control-systems. 
The commissioning provider must bring troubleshooting, problem-solving, diagnostic monitoring, testing, and analysis expertise needed to identify obvious problems and uncover any hidden problems with building systems that must be solved to meet project objectives. The provider must also challenge the use of current equipment, practices, or methods that may be causing problems and identify useful and costeffective solutions for the problems.

\section{Qualifying the commissioning provider}

Currently, there is no universally accepted certification process for commissioning providers. Even if there were, certifications merely indicate that an individual passed a test; they are not guarantees that the person has the experience needed to provide appropriate retrocommissioning services. Appendix $E$ contains two forms that allow the experience of commissioning providers to be described and scoped. These forms are examples and can be modified to meet the information request appropriate to the objectives of a specific project.

Standard approaches should always be used, as appropriate, when seeking commissioning providers:

- evaluate experience;

- request and contact references :

- evaluate ancillary skills such as diplomacy, negotiation, communications, meeting facilitation, listening, investigation, and reporting abilities.

In addition, the following factors should be considered:

- Is commissioning a core business or a primary business component of a firm?

- Are final commissioning reports available for review?

- Do utilities or state and local government organizations have lists of commissioning providers?

It is important that the skills of the commissioning provider match the objectives and scope of the project. For example, if improving IAO is the primary objective for the retrocommissioning, then the individual hired for the job must be skilled at investigating and solving IAQ problems. 


\section{Hiring the commissioning provider}

Initial identification of acceptable commissioning providers may occur through a request for qualifications (RFO) process. The RFO allows evaluation of qualifications without detailed definition of the work to be accomplished. In this way, the desired work scope can be developed more fully while a group of qualified firms and their references are being established and contacted.

Small, less complex projects may not require a request for proposal (RFP) process. However, larger and more complex projects will often dictate use of an RFP and an evaluation of submitted proposals from the group of potential providers selected through the RFQ or by another method. Appendix F contains a checklist of factors to consider when putting together an RFP.

As part of the RFP, the owner or manager should provide a list of expected products or deliverables resulting from the retrocommissioning process. The number and type of deliverables depend on the scope of the project. The following list identifies several possible deliverables:

- all required forms according to an agreed-upon time or conditions framework;

- retrocommissioning plan;

- progress reports according to a schedule;

- all major commissioning meeting minutes (scoping meeting, progress meetings, etc.);

- completed assessment forms;

- diagnostic monitoring, trending, and functional test plans;

- completed functional performance tests;

- Master List of deficiencies and potential improvements (a decision-making tool);

- list of recommended improvements for immediate implementation (based on costeffectiveness);

- final energy saving estimates and calculations;

- list of recommendations for capital improvements for further investigation;

- service contract review findings and recommendations;

- recommissioning schedule ;

- updated/revised building documentation;

- final report (some of the above deliverables may be incorporated into the final report). 
The primary deliverables are the retrocommissioning plan, Master List of deficiencies and potential improvements, list of recommended capital improvements for further investigation, and the final report. These primary deliverables are discussed in more detail in the following sections.

If the project is large or complicated, a preproposal meeting, including a site visit to the facilities included in the scope of the project, may be necessary. This approach allows the selected group of commissioning providers a chance to see the facility and ask critical questions they may have concerning the project. It also tends to "level the playing field" so that each party has the same information in developing bids.

\section{Reviewing and updating building documentation}

During the planning phase, the building documentation that was gathered in preparation for the retrocommissioning is passed on to the commissioning provider for review. If this preparatory task has not been done, then the

Up-to-date, complete building documentation expedites troubleshooting, saving time and money for the building staff. commissioning provider is responsible for obtaining and possibly recreating the documentation needed for the project. This can be an expensive and time-consuming task for the commissioning provider but may be well worth it to the facility manager. Having updated, complete building documentation expedites troubleshooting, saving time and money for the building staff. A comprehensive list of useful documentation is presented in Appendix C.

Accurate, complete, and updated documentation is not only important to the building staff for future use but also immediately important to the commissioning provider, who uses the documentation during the investigation phase of the project for developing the site assessment forms as well as any diagnostic and functional test plans that may be required to verify equipment performance.

When gathering and updating the documentation is a primary task for the commissioning provider, the work is often carried out during the investigation phase rather than in the planning phase of the project.

\section{Developing the plan and holding a scoping meeting}

\section{The retrocommissioning plan}

After reviewing the building documentation package and gaining a clear understanding of the project objectives, the commissioning provider has the primary responsibility for developing the plan, seeking significant input and review from the owner and owner's staff. Including the building operating staff during plan development 
facilitates their desire to see the process succeed. The plan usually includes the following sections:

- general building information .and contact (name, address, phone numbers etc.);

- project objectives;

- building description (brief);

- $\quad$ project scope;

- roles and responsibilities;

- $\quad$ schedule (for primary tasks);

- documentation;

- investigation scope and methods;

- implementation phase;

- project handoff.

The scheduling of project work should coincide with the project objectives. For example, if there is a desire to reduce the number of comfort calls and these calls occur primarily during the cooling season, then the diagnostic testing should be scheduled during peak cooling conditions.

The plan should be viewed as a flexible document that may include some schedule and team member changes during the course of the project. Appendix $G$ contains a sample generic retrocommissioning plan. This plan can be modified as needed to fit the intended project.

\section{The scoping meeting}

Generally, the commissioning provider facilitates the scoping meeting with the plan as the primary focus. The scoping meeting brings all of the team members together to review, discuss, and agree to the retrocommissioning plan. The primary role of the owner or manager is to reiterate the objectives for the project and show support for the retrocommissioning plan. In the meeting, each team member's responsibilities are discussed, and the schedule is agreed to. The scoping meeting sometimes includes others who are invested in the project's success (such as a local utility) but are not directly responsible for performing work on the project.

Work protocols are also conveyed during the scoping meeting. Members of the team-must-be-well-informed-about-what is-expected-of-them-when-they-enter-the building to perform work. The following are some examples of work protocol topics: 
- restrictions on photos or videos (building-wide or in certain areas),

- restrictions on building keys,

- restrictions on special areas in the building (sensitive tenants, etc.),

- sign-in and sign-out requirements,

- necessary identification,

- parking permits,

- safety and emergency requirements and contacts,

- need for escort while in the building or in special areas of the building and who the escort is, and

- special protocols when entering tenant spaces (e.g., the most acceptable times for performing work in tenant spaces).

\section{Planning phase deliverables}

The deliverables that may be expected as part of the planning phase are

- the retrocommissioning project plan (including objectives and scope), and

- scoping meeting minutes (which will become part of the project documentation).

\section{Investigation Phase}

Understanding why building systems are operated and maintained the way they are, identifying deficiencies and potential improvements, and selecting the most costeffective "fixes" are the primary tasks for the investigation phase. In this phase of the project, the team looks at all aspects of the current O\&M program and practices as well as the management structures, policies, and user requirements that influence them. Tasks may include interviewing management as well as building personnel, reviewing current $O \& M$ practices and service contracts, spot-testing of equipment and controls, and trending or electronic data-logging of pressures, temperatures, power, flows, and lighting levels and use.

The investigation phase is generally the most time-consuming and expensive part of the retrocommissioning process. The five steps of the investigation phase are discussed below. 
Retrocommissioning in Action

\section{Performing a site assessment}

The goal of the site assessment is to gain an in-depth understanding of how the building systems and equipment are currently operated and maintained, why they are operated in that way, and what building staff and occupants consider to be the most significant problems. Most projects require the commissioning provider to develop a formal site assessment that includes detailed building staff interviews regarding operating strategies and an in-depth site survey of equipment condition. Sample assessment forms are presented in Appendix $\mathrm{H}$. Assigning building operators to the site assessment who have a historical knowledge of the building and expertise in the control systems expedites this task. The site assessment addresses the following major issues:

- overall building energy use and demand and areas of highest energy use and demand;

- current design and operational intent and actual control sequences for each piece of equipment included in the project;

- equipment nameplate information and equipment condition issues (broken dampers, dirty coils, sensor calibration, etc.);

- current schedules (setpoint, time-of-day, holiday, lighting, etc.);

- the most severe control and operational problems;

- location of the most comfort problems or trouble spots in the building;

- current O\&M practices.

Depending on the scope of the project, the site assessment can take one day to several days to complete. It is not unusual for many problems and possible corrections to reveal themselves during the site assessment. As noted earlier, it may be costeffective to have the assigned building operator make minor adjustments and repairs as the site assessment progresses. These "field fixes" should be summarized on the

- Master List of deficiencies and improvements (the Master List is discussed below) and documented on the applicable site assessment form. Engineering calculations can often be applied later to determine the value of these adjustments and repairs.

The assessment is meant to uncover where the best opportunities are for optimizing the energy-using systems and improving $O \& M$ practices. It provides the starting point from which to evaluate the effectiveness of improvements and O\&M activities. It also provides a basis for recommending where more extensive diagnostics and testing may be appropriate to help better pinpoint the causes of problems or to verify that a problem-does exist. 
A retrocommissioning site assessment differs from an energy audit in that its primary focus is on finding low-cost changes in O\&M practices that improve building operation rather than on technology-intensive capital improvements. However, both have the goal of reducing energy waste and improving the building environment. The site assessment can be performed prior to or as part of an energy audit because it offers ways to optimize system operation, possibly reducing the need for expensive technological solutions.

\section{Developing the Master List of deficiencies and potential improvements}

Concurrent with the site assessment, the commissioning provider begins to develop a Master List of deficiencies and potential improvements. This Master List ultimately becomes an important decisionmaking tool for the facility manager and building staff and is a primary product (deliverable) of the commissioning effort. Every finding from the investigation phase is summarized on the Master List, including those adjustments and repairs made during the course of the investigation process. At a minimum, the list should include the name of the system or piece of equipment, a description of the deficiency or problem, and a suggested solution. A sample Master List is provided in Appendix 1.

The Master List is a dynamic document and may not be fully completed until after the implementation phase.

To better understand the deficiencies and problems, the owner or manager may require the commissioning provider to categorize them according to type or source. For example, problems may fall into four primary categories: maintenance, operation, design, or installation. Understanding where the more costly problems fall helps management understand where organizational improvements may be needed. For example, several problems in the installation category may indicate a need for the owner to require commissioning for future new construction or new equipment installation. Such problems may also suggest taking a hard look at who is providing the installation service. If the majority of problems are maintenance-related, additional staff, more training, or a more comprehensive or better-managed service contract may be needed.

\section{Developing the diagnostic monitoring and test plans}

The information gained from the site assessment may indicate a need to obtain more complete and exact data on when and how systems are actually operating, since the assessment may only identify suspected areas for improvement. If more information-is-needed, the-commissioning provider-develops the necessary-diagnostic monitoring and test plans. 
Diagnostic monitoring and testing allows the commissioning provider to observe space and outdoor temperatures along with critical flows, pressures, speeds, currents, and temperatures of the system components under typical operating conditions. By analyzing this information, the commissioning provider determines whether the systems are operating correctly and in the most efficient manner. Three typical diagnostic methods are EMCS trend logging, stand-alone portable data logging, and manual functional testing. Often, a combination of these methods is used. Appendix $J$ contains a sample diagnostic monitoring plan and trend logging plan, and Appendix $K$ contains a sample functional test plan for a centrifugal chiller.

\section{EMCS trend-logging}

Using the building's EMCS trend-logging capability may be the most cost-effective diagnostic method, as long as the system's sensors have been recently calibrated and team members have high confidence that the system is capable of providing accurate data. However, many systems are limited in their ability to collect, store, and present data. Also, EMCS points (temperature sensors, for example) are permanent, making it impossible to take measurements other than at the location where the points were originally installed. And because it is not unusual for the location of an EMCS sensor be the root of an operational problem, caution should be exercised when using only the EMCS as a diagnostic tool.

\section{Portable data-logging}

For buildings lacking an EMCS or for those having an EMCS with limited data points, using portable electronic data loggers is the best method for short-term diagnostic and monitoring activities. Portable data loggers are battery-powered, small, light, and easily installed and removed without disrupting building occupants. Many come with sophisticated software packages so that data can be downloaded and easily graphed and analyzed on a computer in a variety of ways (see Fig. 3). Gathering data 


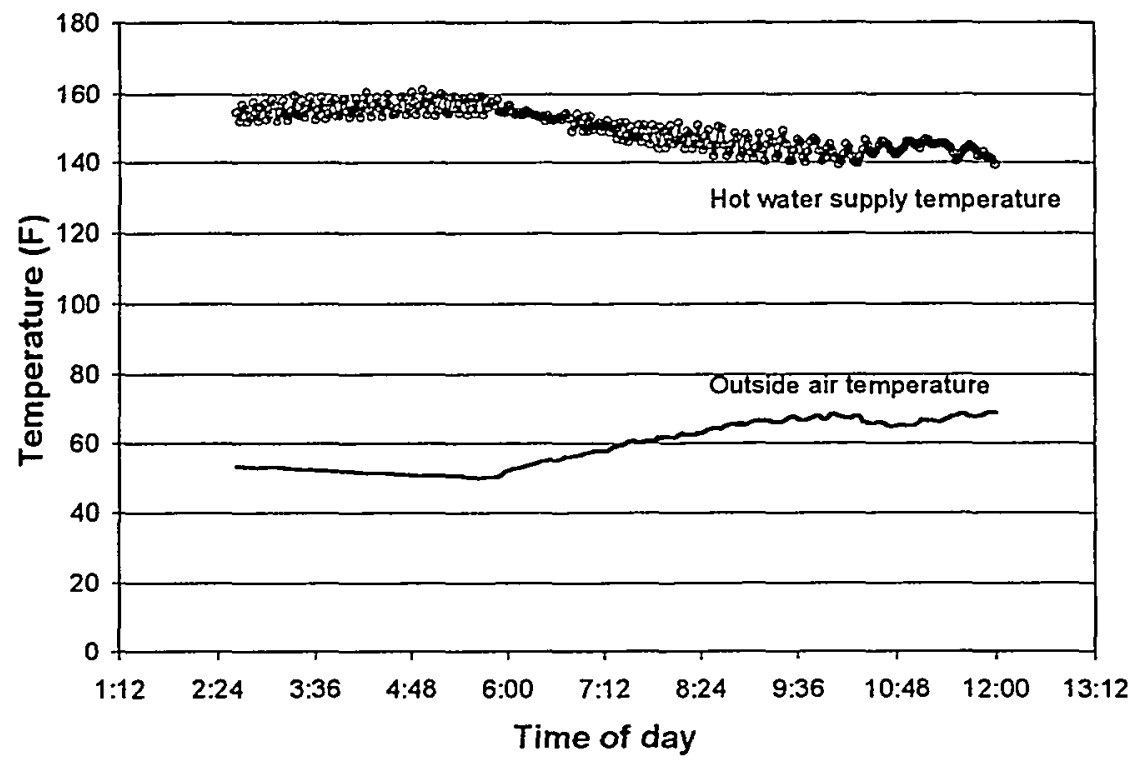

(a) Investigation of reset schedule via time series plot. In this plot the reset schedule appears to be performing correctly. However, taking the analysis a step further, as shown in (b) below, reveals a problem.

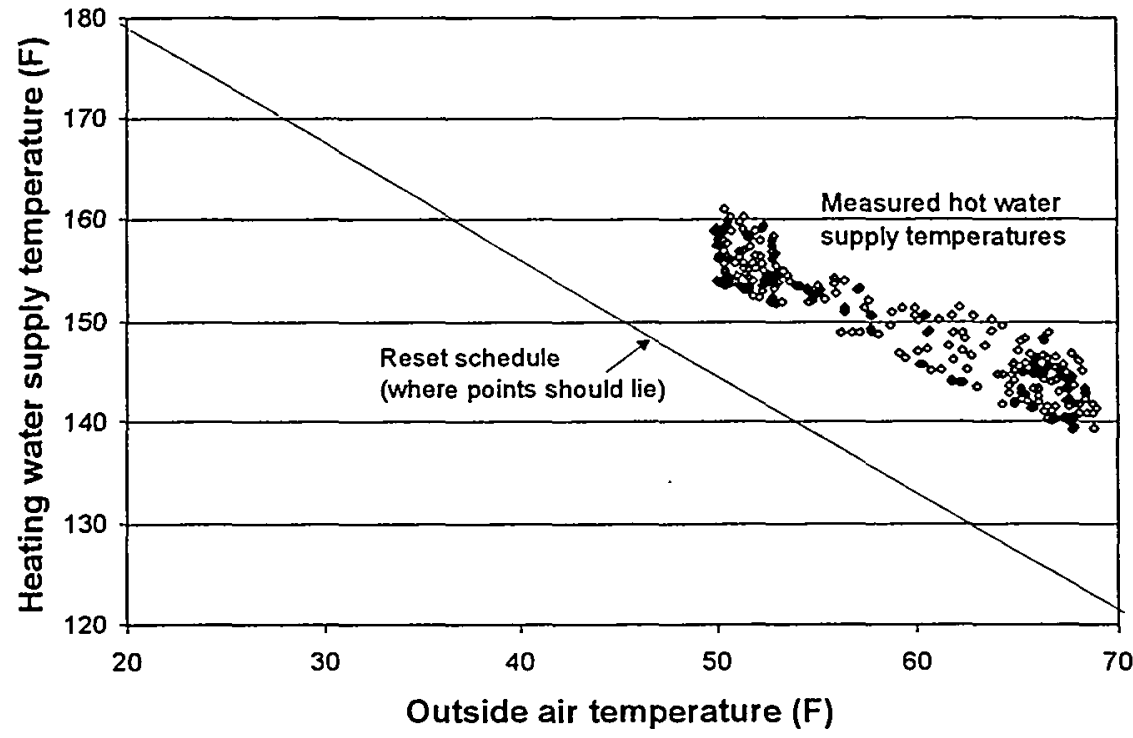

(b) Investigation of reset schedule by plotting one parameter against another. Plotting the heating water supply temperature against the outside air temperature shows that the reset is not performing correctly and needs adjustment. If the reset were performing according to design, the data points would be clustered around the diagonal line.

Fig. 3. Example of data analysis using data derived from a portable data logger. 
in this manner provides a measure of accuracy that manual testing and spot trended or logged at a selected frequency (such as every 2 minutes) for a minimum of two weeks, including a typical weekend.

Short-term diagnostic monitoring serves two purposes: it helps the commissioning team to more accurately locate problems, and it confirms the engineering calculations used to determine which improvements provide the greatest energy savings. During the implementation phase of the project (after the improvements are completed), the original data can be compared against new data to verify that the identified problems are eliminated and that the equipment is operating as expected.

\section{Functional testing}

It may be necessary to functionally test a system or piece of equipment during the investigation process. For example, functional testing is sometimes needed because certain conditions never occurred during the diagnostic monitoring period that may be important to understanding whether a system or piece of equipment is functioning properly or efficiently. The condition can be simulated, or the mode (heating, cooling, economizing, etc.) can be forced through functional testing. If functional testing is needed, it is important to perform the test while the data loggers are still installed or the related EMCS trends are initiated so that the results are permanently recorded and can be easily graphed and analyzed using a computer. When the EMCS is used, test responses can often be viewed as they occur.

When data loggers are not available or when the EMCS is inadequate or nonexistent for trending or viewing system responses, manual functional testing of the system is the only option for verifying correct operation or pinpointing problems. Under these circumstances, the commissioning provider develops detailed test plans for manually testing the equipment and systems. Manual testing involves putting each system or piece of equipment through a series of tests that check its operation under various modes and conditions. Data are gathered by taking spot measurements using hand-held instruments such as multimeters, ammeters, digital thermometers, and light meters. The data are then used to verify correct operation.

\section{Implementing the diagnostic monitoring and test plans}

The commissioning provider and the owner's representative schedule the implementation of the diagnostic monitoring, the testing, and the associated preparatory work. Preparations for monitoring and testing may include checking and calibrating control points such as temperature sensors. When possible, to reduce project costs, the facility staff should complete the calibration work under the direction of the commissioning provider. If data loggers are used, facility staff can usually assist in-the-installation-and-removal-of-the-loggers. The-trend-logging-plan may_be_carried out by the facility staff, but assistance may be required from the controls vendor, 
particularly in developing, formatting, and downloading computer files for analysis by the commissioning provider. Results from monitoring, via trend logs or data loggers, are provided in annotated graphical or columnar format for reporting purposes.

The commissioning provider usually directs the functional tests. Facility staff, a control vendor, or other appropriate parties assist with the hands-on operation of the equipment being tested. The commissioning provider documents manual testing and observed results on the test plan forms. The forms also describe the piece of equipment or the system and the detailed test procedures.

After diagnostic monitoring and testing are completed, the findings are analyzed and checked against the site-assessment information. Any resulting changes, additional deficiencies, or potential improvements are summarized on the Master List.

\section{Selecting the most cost-effective opportunities for implementation}

Once the site assessment and diagnostic testing are complete and the Master List is filled out, owners decide which items on the list provide the most benefit and effectively meet the project objectives. For some projects, managers may want to implement the entire Master List but may need to prioritize the improvements according to cost-effectiveness. For example, in some buildings it may be more cost-effective to implement plant-related control strategies before performing more labor-intensive fixes such as fine-tuning air-side economizing. To help with this decision-making process, the commissioning provider generally completes an analysis of the opportunities and makes recommendations for implementation based on which improvements are most cost-effective. It is not unusual to expect a simple payback of 18 months or less for improvements that produce energy savings. The savings generated from these improvements can sometimes pay for other improvements that have less quantifiable benefits.

Many retrocommissioning improvements are straightforward, and there is confidence in their benefits. In such cases, the building management and staff may not need any savings verification to justify implementation. Other improvements-such as those related to comfort, $\mid A Q$, and equipment malfunction-may not have easily quantifiable savings benefits, but facility staff often want to implement them because they simply want the building to "work right." The building management and staff always make the final decision on which deficiencies and improvements to address first. For additional discussion on verification issues, see "Developing and communicating the objectives" in the first section of this chapter. 


\section{Investigation phase deliverables}

The site assessment may be one of the primary products, if not the only primary product, coming out of the project. Some projects require only completion of the investigation phase, making the assessment and the Master List the primary deliverables. The assessment generally includes gathering information on the condition of equipment, including equipment nameplate information as well as the operating strategies. In many cases it is not necessary to require the entire assessment as a deliverable. For example, if the building does not have an adequate current list of equipment with nameplate information, the maintenance or equipment condition part of the assessment becomes the main deliverable. Or, if the building lacks written control strategies, the operating part of the assessment is valuable for developing this missing information in-house. However, if the assessment findings are the most important product, then the Master List alone adequately fulfills this requirement and the site assessment may be dropped from the deliverable list.

Deliverables that may be expected as part of the investigation phase are

- short-term diagnostic monitoring and functional test plans,

- the Master List of deficiencies and potential improvements,

- completed site-assessment forms (optional),

- completed functional tests, and

- a list of selected improvements for immediate implementation, including costs and ROls.

\section{Implementation Phase}

During the investigation phase, several of the simple, obvious, and less expensive repairs and improvements are usually completed. During the implementation phase, the more complicated and expensive ones are completed. This section discusses implementing improvements and verifying the results, along with some important issues to consider during these activities.

\section{Implementing improvements}

A primary goal for most retrocommissioning projects is actually to implement the major cost-effective improvements so that results can be realized. Although the investigation phase provides important information and products, unless improvements are actually put in place, the retrocommissioning process remains incomplete. Depending on their availability and expertise, in-house $O \& M-$ staff may implement the improvements. However, in some cases the implementation may require outside help. 
For example, hiring a controls contractor may be necessary if in-house staff lacks the expertise, access, or time required to make control strategy changes at the program level.

Retaining the commissioning provider through the implementation phase, whether the implementation work is done in-house or outsourced, is worth considering. Because the commissioning provider has an intimate knowledge of the building systems and needed improvements, having the commissioning provider supervise the implementation phase may ultimately save time and reduce costs. Also, it is often necessary land highly recommended) that some functional retesting be performed after implementation. Retesting is discussed in more detail below. Through the retesting process, the commissioning provider ensures that the improvements are working as expected and that they positively affect other systems and equipment as well as the building occupants. It is not unusual for the retesting to uncover related or hidden problems that could lead to more improvements.

\section{Retesting and remonitoring}

Once an improvement or "fix" is completed, retesting to confirm that the affected equipment is operating properly can be done with EMCS trending, manual testing, or data-logging. In some cases, it may be necessary to use a combination of these methods. For example, retesting might involve manual tests of the function of repaired items such as damper motors or valves to verify that they stroke properly, followed by EMCS trending or data-logging to determine that they are modulating to maintain the desired setpoint at the appropriate times.

It is often desirable and enlightening to reinstall several if not all of the data loggers (or reinitiate the original EMCS trends) and remonitor operations to obtain several days of post-implementation data. The data are then compared to the original data (preimplementation data) in order to confirm that the improvements are integrated and have the desired overall positive effect for the building. This technique can also be used to benchmark the final performance of the improvements. This benchmarking information can then be used to establish criteria or parameters for tracking whether or not the improvements are performing properly throughout the life of the equipment or systems. (See also the discussion of the project hand-off phase below.)

Retesting and remonitoring may reveal the need for further improvements. Often, addressing one deficiency uncovers other opportunities for more savings or improved comfort. At this point it is also important to use any of the applicable post-test and monitoring data to check and adjust the original energy savings estimates to make them as accurate as possible. 


\section{Implementation phase deliverables}

The following deliverables may be expected as part of the implementation phase

- completed repairs and improvements (these can be noted on Master List);

- final estimated energy savings calculations for energy saving improvements.

\section{Project Hand-Off Phase}

Although project handoff is the final phase, it is not the end of the owner's or building staff's effort to maintain the investment in retrocommissioning. The products and recommendations from this phase of the project should be integrated into the building's $O \& M$ and energy management program so that the estimated return on the retrocommissioning investment can be realized. The three steps in the project hand-off phase are discussed below.

\section{Completing the final report}

The commissioning provider prepares a comprehensive final report that includes several of the required deliverables for the project. A typical final report contains the following:

- executive summary;

- analysis of major findings and results;

- building and systems descriptions;

- scope of the commissioning project;

- Master List of improvements, including training needs and maintenance recommendations;

- detailed description of improvements that were implemented, with cost and savings information;

- list of recommended capital improvements for further investigation (discussed below);

- original and corrected commissioning plan;

- EMCS trending plan and logger diagnostic, monitoring plan and results;

- all completed functional tests and results. 
During the normal course of projects, the commissioning provider may be required to review current equipment and system efficiencies, operating strategies, and conditions not only for $O \& M$ improvements but also for possible energy-efficient capital improvements. Although retrocommissioning does not involve implementing expensive energy-efficiency measures, it is often the first step toward obtaining these improvements. Therefore, the commissioning provider should provide a list of recommended improvements as part of the project handoff. The list need not be limited to energy-saving or cost-saving capital improvements. Regarding the energy savings measures, however, the list recommends areas for further investigation and should not require extensive supporting energy calculations or building models. If and when the opportunity for further improvements arises or the facility budget permits such improvements, the list can be used as a starting point for a comprehensive energy study. The list should go beyond the generic to include realistic and customized recommendations based on the facility. It should reference equipment names, room numbers, areas of the building, and so on.

Figure 4 is an example of recommended capital improvements taken from an actual project.

- Energy-efficient lighting retrofit (all interior lighting including exit lighting)

- Addition of lighting sweep control for interior lights not in 24-hour-use areas

- Addition of occupancy sensors for lighting in offices, restrooms, conference rooms, storerooms building-wide

- Addition of photo cells on exterior lights on south side of the building

- Daylighting controls for corridors and lobbies with extensive windows

- Variable frequency drives on primary air handlers \#1 and \#2

- $\mathrm{CO}_{2}$-based ventilation control for conference room 2000

Fig. 4. Example of a list of recommended capital improvements.

\section{Maintaining the investment benefits}

Developing a recommissioning schedule and procedures, instituting methods for tracking results, and training staff are key elements in retaining the cost savings and other benefits gained from retrocommissioning throughout the lives of the building equipment and systems.

\section{Recommissioning procedures and schedule}

In this guide, recommissioning has been defined as "a periodic event that reapplies the original commissioning tests in order to keep the building operating according to design or current operating needs." Owner commitment to performing regular recommissioning increases the chances that the improved equipment and systems will continue to perform according to their original intent. In order to ensure continuing performance-and energy-cost savings, a-recommissioning-schedule-should be -..- 
incorporated into the overall O\&M plan for the facility. The commissioning provider may be required to develop the schedule as one of the project deliverables.

Depending on the types of the improvements and how often the building changes, recommissioning schedules can vary considerably. If building use remains stable and tenants rarely if ever request major changes (such as moving or constructing walls or installing additional ductwork), then recommissioning may be scheduled less frequently than for a building where changes occur often or are significant. Also, the frequency of recommissioning activities may be different for different areas of the building. Equipment that serves an area with constant tenant requests for operating schedule changes or construction, etc., will need recommissioning more often than equipment that serves more stable areas. In some cases, it may be convenient and appropriate to incorporate recommissioning activities into the regular annual or semiannual preventive maintenance requirements. This approach may be particularly important for major plant equipment. Any one of or a combination of the following parties may perform recommissioning:

- trained in-house O\&M staff,

- trained outside O\&M service contractors, and/or

- commissioning provider.

\section{Tracking results}

Continuing to evaluate the results of the retrocommissioning project over time will help owners and managers understand when it may be important to reevaluate the improvements to make sure they are still functioning properly. It may be appropriate and cost-effective to continue using some of the M\&V methods discussed in the Planning Phase section. For example, simply continuing to log the frequency of comfort complaints can often indicate whether problems have arisen with the implemented improvements. Tracking energy bills and the energy use index for each retrocommissioned building and comparing energy use indexes among similar buildings are other inexpensive ways to check for possible problems. (Owners should be aware, however, that these are not always accurate tracking methods because of the effects that weather, occupancy, and building use changes have on energy use. These effects can sometimes either mask problems or suggest problems when none actually exist.)

As long as regular calibration checks are performed on strategic sensors, staff can use the EMCS to track whether or not improved control strategies and sequences of operation are still performing as expected. Trends may be either permanently or periodically set up to gather data that can be compared against benchmark criteria or parameters. When the trended data moves outside those parameters, a problem may exist. The benchmarking parameters can be generated during the post-implementation 
monitoring or EMCS trend logging, as discussed in the Implementation Phase section. The commissioning provider may be the best person to set up methods for tracking the performance of improved systems.

\section{Project closeout meeting}

Once the commissioning provider has submitted the final report for review by the owner and the owner's staff, it may be appropriate to hold a project closeout meeting with the retrocommissioning team. Such a meeting is valuable for discussing what worked and what didn't, and for identifying the lessons learned during the project. It also provides an important opportunity to recognize individual successes, celebrate the overall success of the project, and discuss next steps. Next steps may include developing an organization-wide plan for retrocommissioning all of the organization's buildings. Next steps may also include selecting an approach for deciding which capital improvements to install.

The final report, including the test and diagnostic procedures used during the retrocommissioning effort, should be delivered to the owner and the person or persons responsible for the recommissioning. Reapplying these procedures during recommissioning greatly reduces the cost of the recommissioning effort.

Acceptance of the final report by the owner or owner's representative concludes the hand-off phase of the project.

\section{Hand-off phase deliverables}

Typical deliverables for the hand-off phase are

- the final report,

- recommended capital improvements for future investigation,

- revised or upgraded building documentation (if required as part of the project), and

- the recommissioning plan or schedule and methods for tracking improvements. 
F. retrocommissioning several buildings simultaneously rather than one at a time. Because of the learning curve involved with implementing anything new, however, it may be wise to start with one or two buildings to ensure that the process, the team, and the method of selecting a commissioning provider are working as expected. Much can be learned from doing just a single project. The knowledge gained from this experience can feed into organization-wide guidelines that incorporate commissioning and retrocommissioning into the organization's energy management program.

For organizations that do not have a formal energy management program, retrocommissioning can be a first step in developing one. Some building owners use commissioning and retrocommissioning as a foundation and catalyst to ensure that all of their buildings' systems perform optimally. They consider this fundamental to the success of their organization's overall energy management program. Developing or finetuning the energy management program, including the incorporation of commissioning and retrocommissioning guidelines, can be an additional task for the commissioning provider. 


\begin{abstract}
A
Ithough this guide focuses on the retrocommissioning process and its advantages, all three types of commissioning-retrocommissioning, commissioning, and recommissioning-play an equally important role in ensuring that buildings perform efficiently and provide comfortable, safe, and productive work environments for owners and occupants. For new construction and retrofit projects, commissioning should be incorporated early, during design, and last throughout the length of the project. For buildings that were never commissioned, the retrocommissioning process can yield a wealth of cost-saving opportunities while enhancing a building's environment. Finally, once a building is commissioned or retrocommissioned, incorporating recommissioning into the organization's $O \& M$ program (by periodically reapplying the original diagnostic testing and checklist procedures) helps ensure that cost savings and other benefits gained from the original process persist over time.
\end{abstract}


ASHRAE. ASHRAE Guideline 1-1996, The HVAC Commissioning Process. New York: American Society of Heating, Refrigerating and Air-Conditioning Engineers, 1996.

Building Commissioning Guidelines. 2nd ed. Portland, Ore.: Bonneville Power Administration, 1992.

Building Commissioning, the Key to Quality Assurance. DOE/EE-0153. Washington, D.C.: U.S. Department of Energy, May 1998.

Casault, R. An Integrated Approach to Building Commissioning. ASHRAE Professional Development Seminar. 1998-. Described online at http://www.ashrae.org/ EDUC/pdsinfo.htm.

Chao, M., and D. Goldstein. Energy Efficiency and Property Valuation by Appraisers and Financial Markets: The Need for Commissioning and Credible Performance Documentation. San Francisco: Institute for Market Transformation, September $1997,1-6$.

Energy Information Administration (EIA). Commercial Buildings Energy Consumption and Expenditures, 1992. DOE/EIA-0318(92). Washington, D.C.: EIA, 1995.

Gregerson, J. "Cost Effectiveness of Commissioning 44 Existing Buildings." In Proceedings of the National Conference on Building Commissioning, Huntington Beach, Calif., April 28-30, 1997.

Herzog, Peter. Energy-Efficient Operation of Commercial Buildings: Redefining the Energy Manager's Job. New York: McGraw-Hill, 1996.

NEBB Procedural Standards for Building Systems Commissioning. Rockville, Md.: National Environmental Balancing Bureau, 1993.

Sharp, T. R. "Energy Benchmarking in Commercial Office Buildings." Pp. 321-29 in Proceedings of the ACEEE 1996 Summer Study on Energy Efficiency in Buildings, vol. 4, Pacific Grove, Calif., 1996. 


\section{Sources for Commissioning Guidelines, Guide Specifications, and Sample Functional Performance Tests}

Appendix A contains a comprehensive list of informational sources for commissioning. Although many of the documents address commissioning for new construction or new installations, much of the material can be modified to fit the retrocommissioning process. 


\section{Sources for Commissioning Guidelines, Guide Specifications and Sample Functional Performance Tests}

\begin{tabular}{|c|c|c|c|}
\hline Source & Guidelines & $\begin{array}{l}\text { Guide } \\
\text { Specs }\end{array}$ & $\begin{array}{c}\text { Sample } \\
\text { Tests }\end{array}$ \\
\hline $\begin{array}{l}\text { Model Commissioning Plan and Guide Commissioning } \\
\text { Specifications, USDOE/PECI, 1997. NTIS: \# DE } \\
\text { 97004564 1-800-553-6847. PECI Web site: } \\
\text { http://www.peci.org } \\
\text { The HVAC Commissioning Process, ASHRAE Guideline } \\
\text { 1-1996, 1996. ASHRAE Publications Dept., } 1791 \\
\text { Tullie Circle, NE, Atlanta, GA 30329. } \\
\text { Engineering and Design Systems Commissioning } \\
\text { Procedures, U.S. Army Corps of Engineers, } 1995 \text { (ER } \\
\text { 1110-345-723). Department of the Army, U.S. Army } \\
\text { Corps of Engineers, Washington, D.C. 20314-1000. } \\
\text { Commissioning Specifications, C-2000 Program, Canada, } \\
\text { 1995. C-2000 Program, Energy Mines \& Resources, } \\
\text { Energy Efficiency Division, 7th Floor, 580 Booth St., } \\
\text { Ottawa, Ontario, Canada K1A OE4. } \\
\text { Building Commissioning Guide, U.S. General Services } \\
\text { Administration and USDOE, 1995. Prepared by } \\
\text { Enviro-Management \& Research, Inc. 703-642-5310. } \\
\text { Commissioning Guide Specification, Facility Management } \\
\text { Office, University of Washington, 1993-6. } \\
\text { http://weber.u.washington.edu/ fsesweb/ } \\
\text { Commissioning Guidelines, Instructions for Architects } \\
\text { and Engineers, State of Washington, 1995. Dept. of } \\
\text { General Administration, Div. of Engineering \& } \\
\text { Architectural Services, 360-902-7272. } \\
\text { Commissioning of HVAC Systems, seminar/workshop } \\
\text { training materials, University of Wisconsin, Madison, } \\
\text { 1994. 800-462-0876 or 608-262-2061 } \\
\text { Laboratory HVAC Systems: Design, Validation and } \\
\text { Commissioning, ASHRAE collection of } 11 \text { papers, } \\
\text { 1994. } \\
\text { Commissioning Smoke Management Systems, ASHRAE } \\
\text { Guideline 5-1994. ASHRAE Publications Dept., 1791 } \\
\text { Tullie Circle, NE, Atlanta, GA 30329. } \\
\text { Standard HVAC Control Systems Commissioning and } \\
\text { Quality Verification User Guide, U.S. Army Const. } \\
\text { Engineering Research Laboratories, 1994. Facilities } \\
\text { Engineering Applications Program, U.S. Army } \\
\text { Engineering and Housing Support Center, Ft. Belvoir, } \\
\text { VA 22060-5516. FEAP-UG-GE-94/20. }\end{array}$ & $\begin{array}{c}\text { Yes } \\
\text { D, C } \\
\text { No } \\
\text { Yes } \\
\text { d, c } \\
\\
\text { Some } \\
\text { C } \\
\text { Yes } \\
\text { C }\end{array}$ & $\begin{array}{c}\text { Some } \\
d, c \\
\text { Some } \\
d, c \\
\text { *YES } \\
C \\
\text { No } \\
\text { *YES } \\
C \\
\text { No }\end{array}$ & $\begin{array}{c}\text { No } \\
\text { Some }\end{array}$ \\
\hline
\end{tabular}




\begin{tabular}{|c|c|c|c|}
\hline Source & Guidelines & $\begin{array}{l}\text { Guide } \\
\text { Specs }\end{array}$ & $\begin{array}{c}\text { Sample } \\
\text { Tests }\end{array}$ \\
\hline 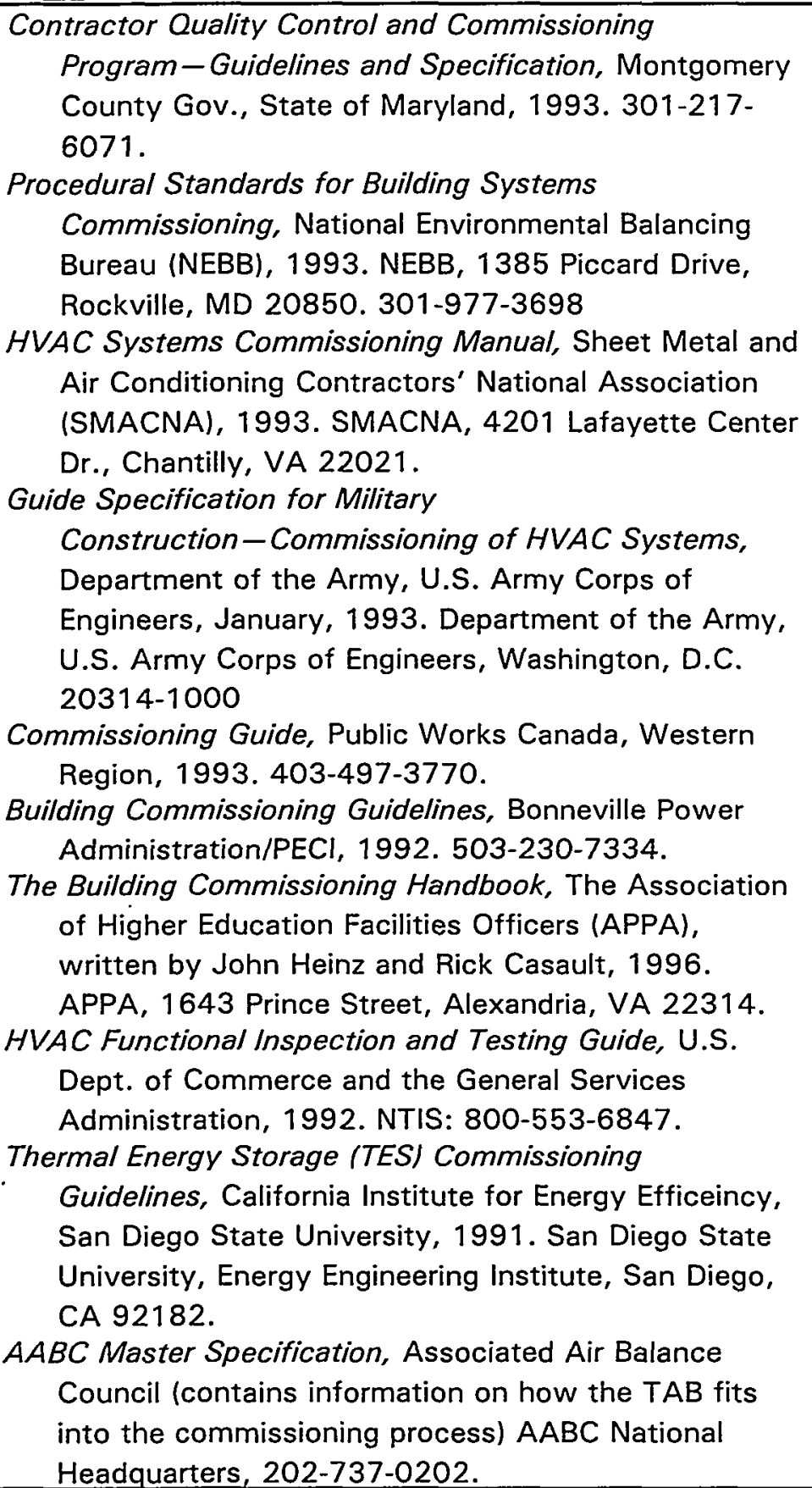 & $\begin{array}{l}\text { Some } \\
\text { d, c } \\
\text { YES } \\
d, C \\
\text { YES } \\
d, C\end{array}$ & $\begin{array}{c}\text { Yes } \\
\text { d, C } \\
\text { Some } \\
\text { c } \\
\text { YES } \\
\text { C }\end{array}$ & $\begin{array}{c}\text { No } \\
\text { Some } \\
\text { No }\end{array}$ \\
\hline
\end{tabular}


Web Sites Containing Commissioning Information

EPA/DOE Energy Star Building Label

Florida Design Initiative

Jackson Associates, Inc.

NEBB

Oregon Office of Energy

ORNL Buildings Technology Center

$\mathrm{PECl}$

Texas A\&M Energy Systems Lab

University of Washington

USDOE/FEMP http://www.epa..gov/buildinglabel

http://fcn.state.fl.us/fdi/e-

design/online/edo.htm

http:/www.maisy.com

http://www.nebb.org/bsc-man.htm

http://www.cbs.state.or.us/external/ooe/cons/

bldgcx.htm lamong other things, this site contains the full text of Commissioning for

Better Buildings in Oregon

http://eber.ed.ornl.gov/commercialproducts/

cbenchmk.htm

http://www.peci.org

http://www-esl.tamu.edu

http://wiveber.u.washington.edu/ fsesweb/

http://www.eren.doe.gov/femp/techassist.html (among other things, this site contains the full text of the DOE/GSA Building Commissioning Guide

For copies of the resource booklet What Can Commissioning Do For Your Building, contact:

PECl

921 SW Washington Street

Suite 312

Portland, OR 97205

503-248-4636 ext. 204 (voice)

503-295-0820 (fax)

peci@peci.org (e-mail) 


\section{Appendix B}

\section{Building Information Summary}

Appendix $\mathrm{B}$ contains a list of typical building characteristics that can be placed in a spreadsheet or a database for comparing multiple buildings. This is useful for owners with multiple facilities who are interested in gaining a preliminary understanding of their building stock regarding retrocommissioning opportunities. 


\section{Building Identification (Name or Number)}

General Information

Building type (e.g., office, warehouse, hospital)

Number of occupants

Size (gross square footage)

Year of construction

Year of last renovation

\section{Building Equipment}

Central heating plant (boilers)

Central cooling plant (chillers)

Packaged units

District heating

District cooling

Computer energy management system

Age of primary heating equipment

Age of primary cooling equipment

\section{Energy Data}

Annual hours of operation

kWh per year

Annual electric use in $\mathrm{kWh}$ per square foot

Peak demand for last 12 months

Natural gas ccf per year

Annual gas use in BTU per square foot

BTU per square foot per year, all fuels

District heating (lb of steam per year)

District cooling (TN hours per year)

Average annual BTU per square foot for region or city for similar type buildings 
Appendix $C$

Checklist of Building Documentation 


\section{Checklist of Building Documentation}

\section{General information}

$\square$ Current set of all mechanical prints, electrical riser diagrams, and piping drawings (as-builts) including roof or mechanical room layouts of HVAC equipment

$\square$ Building equipment list (with nameplate information if available)

․ Test and Balance Report for air and water (most recent and original, if available)

$\square$ Recent energy audits (within the last 5 years)

口 Names, addresses, and phone numbers of current service contractors

- Current energy accounting reports-previous 12 months.

$\square$ Copies of the utility bills (water, electric, gas, etc.) for the past 2 years

$\square$ Rate schedules, supply contracts, other information

\section{Energy management control system}

$\square \quad$ Name and address of installing contractor, distributor, manufacturer, and present service contractor (some of these may be the same)

․ Manufacturer's literature (cut sheets)

口 Control submittals (if still available)

$\square$ Operation and maintenance manuals

․ User guide or manual

$\square$ Control drawings

- Written control strategies and sequences of operation

$\square$ Time-of-day schedules by zone or tenant space

- Setpoint schedules by zone or tenant space for normal day, night setback (night low limit), and setup

․ Points list

․ Hard copy of the program

$\square$ Software and firmware versions and latest revisions

ㅁ Service contract

Guarantee and warranties still in effect

\section{Lighting}

$\square$ Lighting control submittals (occupancy sensors, sweep controls, daylighting controls, etc.)

․ Control drawings (or reflected ceiling plans showing locations of lighting sensors or list of lighting sensor locations).

ㅁ Manufacturer's literature (cut sheets)

口 Schedules

․ Guarantees and warranties still in effect

\section{Operation and maintenance}

ㅁ Preventive maintenance plan/schedules, logs or both (manual or computerized)

口 Invoices or O\&M records for last 3 months of service 
$\square$ Copy of any current service contracts (if applicable)

$\square$ List of recent repairs or rebuilds

$\square$ List of new equipment installations not on current list of equipment

\section{HVAC and refrigeration equipment}

(Chillers, pumps, air handlers, cooling towers, packaged $\mathrm{A} / \mathrm{Cs}$, heat pumps, terminal boxes, thermostats, heat exchangers, evaporative coolers, refrigeration compressors, condensers, air compressors, air dryers, VFDs, etc.). Place the equipment names at the tops of the columns and use check marks to indicate which documentation is available for each.

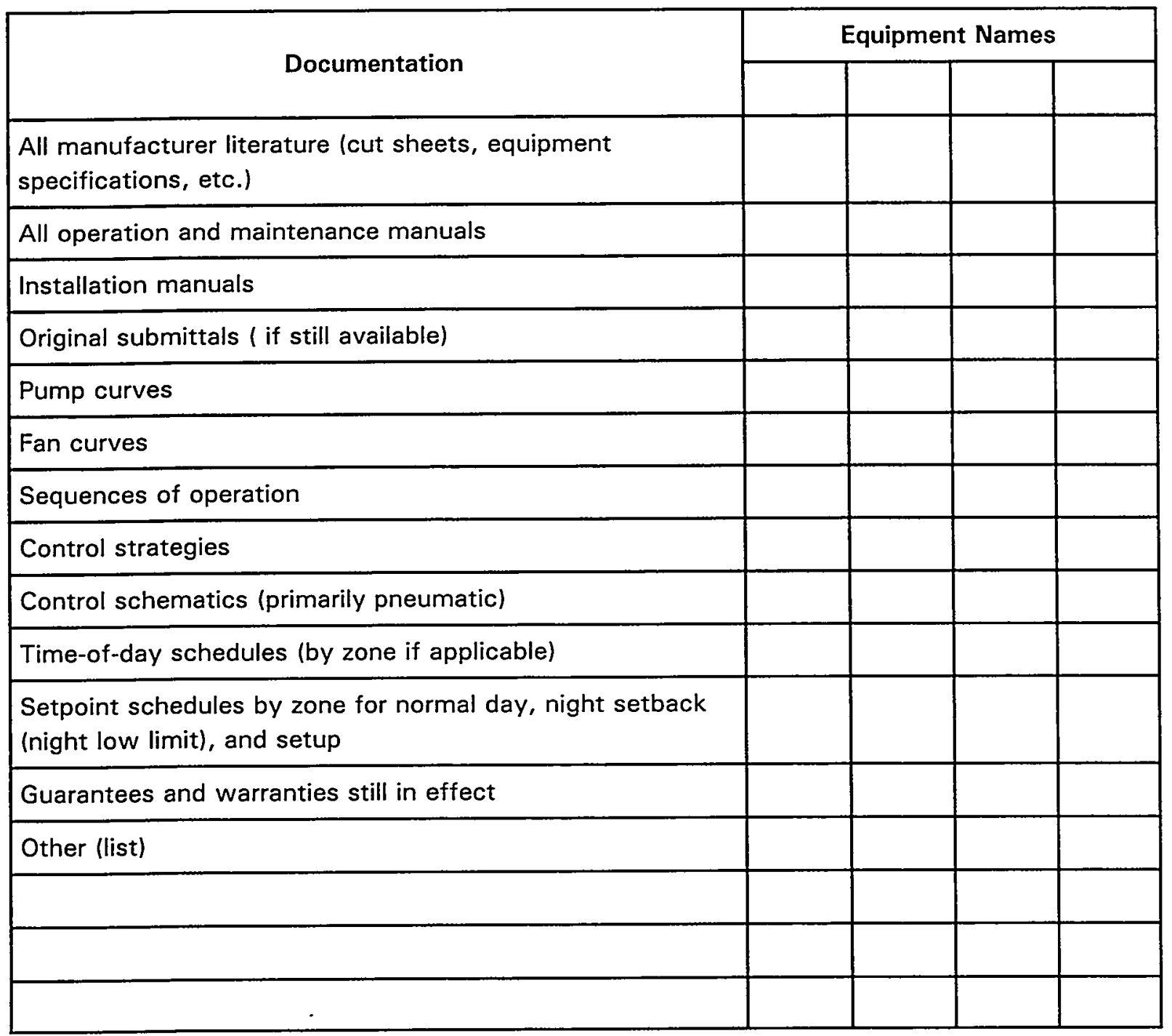


Appendix D

Commissioning Tools Checklist 


\section{Commissioning Tools Checklist}

The following is a list of tools typically used for commissioning:

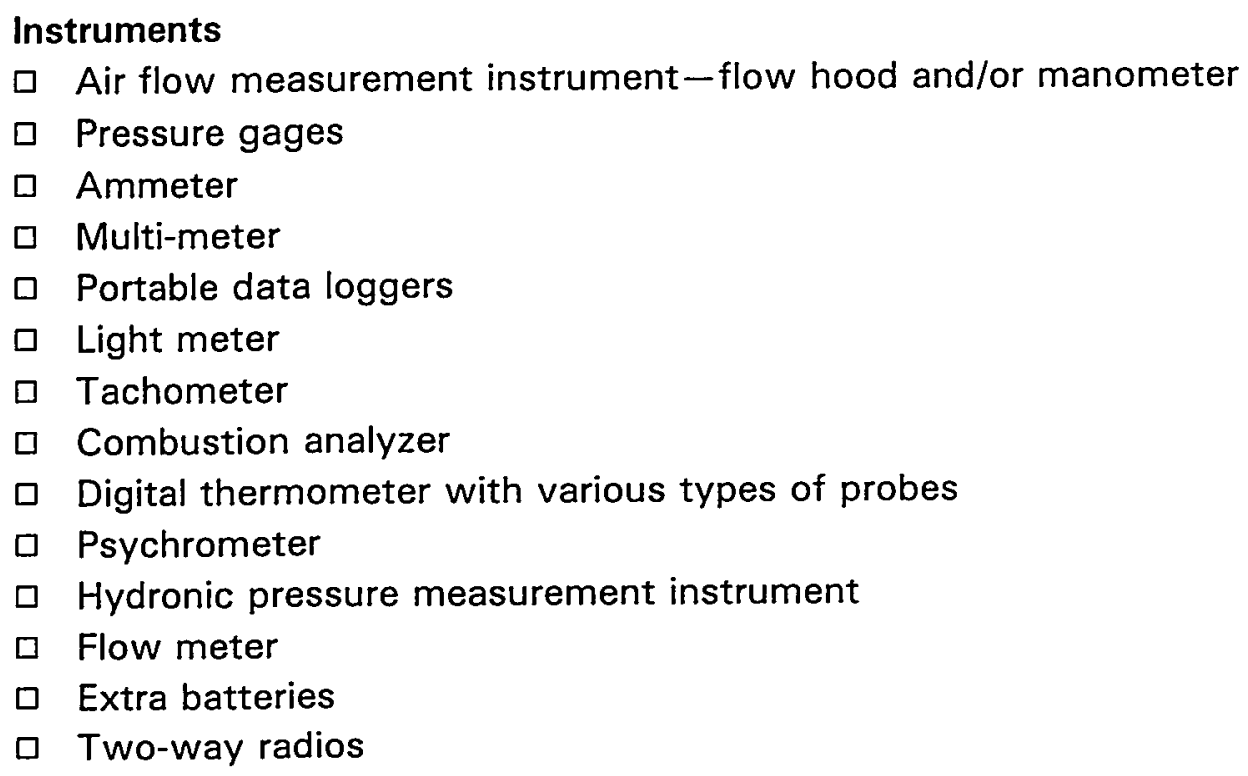

$\square$ Air flow measurement instrument-flow hood and/or manometer

$\square$ Pressure gages

$\square$ Ammeter

․ Multi-meter

口 Portable data loggers

$\square$ Light meter

$\square$ Tachometer

$\square$ Combustion analyzer

$\square$ Digital thermometer with various types of probes

口 Psychrometer

ㅁ Hydronic pressure measurement instrument

$\square$ Flow meter

口 Extra batteries

$\square$ Two-way radios

\section{Hand tools}

$\square$ Cordless drill and bits

$\square$ Allen wrenches

$\square$ Duct tape

$\square$ Extension cord

$\square$ Flashlight

․ Hairdryer

Hot and cold chemical packs

$\square$ Pliers, wrenches, vice grips, etc.

$\square$ Pocket knife

口 Ladder

$\square$ Screwdrivers

$\square$ Sockets and driver

$\square$ Nut drivers

Rags

ㅁ Flexible mirror

\section{Miscellaneous}

$\square$ Tape recorder

․ Camera and film and/or video camera and tape

口 Calculator

ㅁ Test forms

$\square$ Phone list 
$\square$ Building documents, files

$\square$ Business cards

$\square$ Clipboard, paper, pens, pencils

$\square$ Personal protective equipment

\section{Instrument Calibration}

It is important that the commissioning provider's test instruments have up-to-date and valid calibration documentation. These may be in the form of a certificate from the manufacturer. If the instruments used to measure variables, check sensor calibration, or troubleshoot problems are not calibrated on a regular basis, test-instrument errors could cause energy waste and comfort problems as well as wasted time troubleshooting.

Instrument calibration may be performed by companies or government agencies regularly engaged in calibrating similar instruments or by the instrument's manufacturer. In either case, some form of documentation usually is provided stating that the instrument was calibrated and the date of the calibration. The building owner or manager may request a copy of the documentation. 


\section{Commissioning Firm Experience}

This appendix contains forms that can be used to describe the experience of commissioning providers. They are examples that can be modified to fit the objectives of specific projects. 


\begin{tabular}{lll}
\hline Company Name & Contact Person & Title \\
& & \\
\hline Address & City, State/Prov. & Zip \\
\hline Telephone & Fax & E-Mail
\end{tabular}

\section{Commissioning Activities}

Percentage of overall business devoted to commissioning services How long has the firm offered commissioning services Average number of commissioning projects performed each year

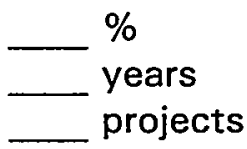

Systems (technologies) for which firm has provided commissioning services (check all that apply)
$\square$ Pkg or split HVAC
$\square$ Daylighting
$\square$ Commercial refrigeration
$\square$ Chiller system
$\square$ Electrical, general
$\square$ Telecommunications
$\square$ Boiler system
$\square$ Electrical, emerg. power
$\square$ Thermal energy storage
$\square$ Energy mgmt. system
$\square$ Envelope
$\square$ Labs and clean rooms
$\square$ Variable freq. drives
$\square$ Fire/life safety
$\square$ Lighting controls
$\square$ Plumbing

Number of registered professional engineers on staff who have directed commissioning projects:

The firm has provided commissioning services in the following (check all that apply):

\begin{tabular}{|l|c|cc|}
\hline \multicolumn{1}{|c|}{ Building sector } & $\begin{array}{c}\text { New construction } \\
\text { Major renovation }\end{array}$ & $\begin{array}{c}\text { Existing buildings } \\
\text { (building tune-up) }\end{array}$ & $\begin{array}{c}\text { Equipment } \\
\text { replacement }\end{array}$ \\
\hline Office & $\square$ & $\square$ & $\square$ \\
\hline Retail & $\square$ & $\square$ & $\square$ \\
\hline Grocery & $\square$ & $\square$ & $\square$ \\
\hline Hospitals & $\square$ & $\square$ & $\square$ \\
\hline Laboratories & $\square$ & $\square$ & $\square$ \\
\hline Schools & $\square$ & $\square$ & $\square$ \\
\hline Universities & $\square$ & $\square$ & $\square$ \\
\hline Federal, state, local gov't & $\square$ & $\square$ & $\square$ \\
\hline Industrial/manufacturing & $\square$ & $\square$ & $\square$ \\
\hline Special purpose: prisons, & $\square$ & $\square$ & $\square$ \\
museums, libraries, etc. & & & $\square$ \\
\hline
\end{tabular}




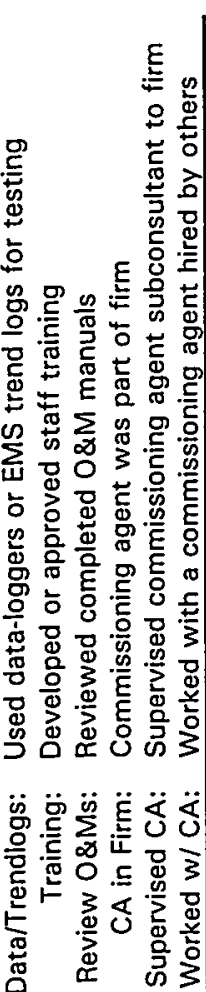

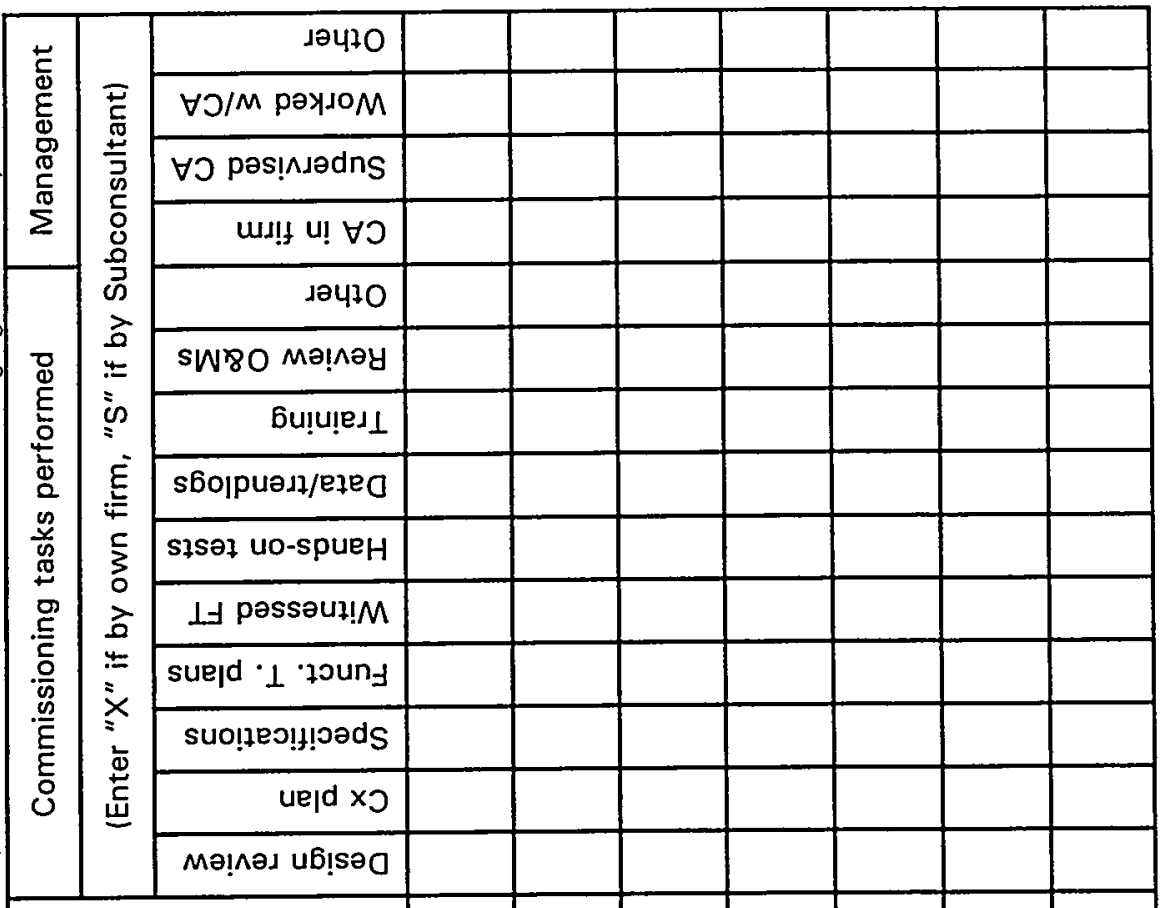

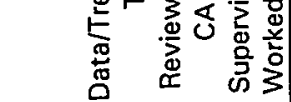

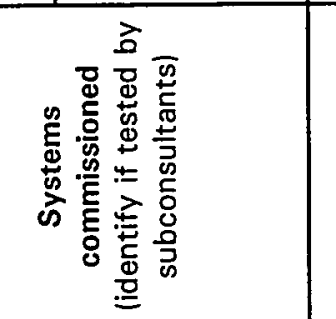

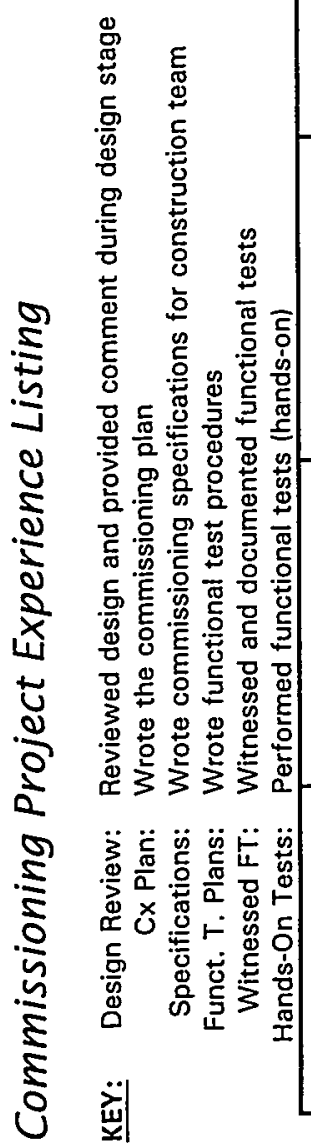

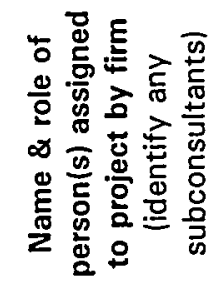




\section{Appendix $F$}

\section{Request for Proposal Checklist for Retrocommissioning Services}

The checklist contained in this appendix is a guide for individuals tasked with developing an RFP for commissioning services for existing buildings. It is not a comprehensive checklist for developing an entire RFP from start to finish, but it includes items specific to retrocommissioning that will help obtain a realistic proposal. 


\section{$\checkmark$ RFP Checklist for Retrocommissioning Services}

Include clear objectives and what priority each has (energy, comfort, building control, etc.)

Provide information about the building. As a minimum, include

- A brief building description

- Square footage

- A general HVAC description (central plant as well as distribution systems for both heating and cooling); controls system description

- A list of major equipment, including number and age of each type

- A brief renovation, retrofit, and equipment replacement history

- A building use description

Provide as much information on the trending capabilities of the energy management control system as possible. Ideally, a complete points list should be provided. This increases the bidders' ability to more accurately budget the data acquisition tasks. Also state whether the system can be accessed remotely (by modem).

Provide a list of available up-to-date building documentation.

Include as complete a scope of work as possible. State the type of commissioning expected (existing-building, new equipment, or combined new and existing systems). If it is unclear what the scope of work can realistically include, allow step one of the project to address developing a detailed scope of work. Or hire an experienced commissioning consultant to help develop the scope of work for inclusion in the RFP. The scope of work should include a list of equipment needing commissioning. Also, clearly state for each phase of the project (planning, investigation, implementation, and integration) the responsibilities of the in-house building staff and/or service contractor and the commissioning provider. (For guidance, refer to Appendix G and the section of this document titled "Strategies for Reducing Commissioning Costs.")

If the preferred data acquisition methods are known le.g., datalogging, trending, functional testing) state them; otherwise, specifically ask that the bidder detail the approach on these issues.

Indicate what is expected for each of the retrocommissioning phases (planning, investigation, implementation, and handoff). It is especially important for the bidders to know whether the contract proceeds through the implementation phase or ends with the investigation phase (detailed site assessment).

Request a statement of the commissioning provider's general approach and a skeletal commissioning plan for the project. 
List the specific types of support that the commissioning provider can expect from the facility staff and service contractors (particularly the controls vendor) and provide information on the skill level of each of the facility staff. State how much testing and investigation can be done by facility staff.

$\square$ When requiring savings calculations or estimates, state the desired method for completing the work (qualitative ranking of measures for implementation using expert judgment, cost estimates and engineering calculations of savings, costs from actual bids, and bin or computer simulations of savings).

$\square$ Any cost or energy savings calculations or estimates required of the commissioning provider prior to implementation and after post-verification should be clearly stated with the desired method.

$\square$ List the required commissioning provider qualifications and qualifications for any subcontractors.

$\square$ Request work examples from previous projects (final report, Master List of findings, etc.)

$\square \quad$ List the RFP selection criteria.

$\square$ Give a cost range for the project.

$\square$ Provide a list of required deliverables (see document section titled "Selecting a Commissioning Provider").

$\square$ Other RFP checklist items: 


\section{Appendix $G$}

\section{Sample Retrocommissioning Plan}

Appendix $G$ presents a sample final retrocommissioning plan, including the corrections and changes that occurred as the project progressed. A plan may be more or less detailed depending on the scope and complexity of the project. The following items are the major information headings for a typical plan:

General Building Information and Contact (name, address, phone numbers).

Project Objectives

Building Description (brief)

Project Scope

Roles and Responsibilities

Schedule (for primary tasks)

Documentation

Investigation Scope and Methods

Implementation Phase

Project Handoff 


\section{The Retrocommissioning Plan}

Final Plan

Changes and corrections from draft plan are noted in italics.

Building Name:

Address:

City/State/Zip:

Main Contact:

Address:

Phone:

Building Sq. Ft.

Commissioning Provider:

Firm:

Address:

City/State/Zip:

Phone:
Office Building One

100 Office Avenue

Big City, My State and Zip

Building Manager, Facility Manager

Same

Voice \#:

155,000 (Gross)

Commissioning Expert

Commissioning for All Seasons

100 Commissioning Ave

Big City, State and Zip

Voice \#:

FAX \#:

FAX \# :

\section{Primary Project Objectives}

There are three primary objectives for performing retrocommissioning in Office Building One:

- Obtain cost-effective energy savings from optimizing how the building's energyusing systems are operated and maintained. Perform short-term monitoring to improve energy savings calculations and verify results.

- Identify and recommend improvements to operations and maintenance procedures, focusing on those activities that sustain optimal energy performance and reduce operating costs. Review the existing service contract and determine how it can more successfully integrate with the overall building O\&M program.

- Identify HVAC-related health and safety issues as they present themselves during the normal course of the commissioning work and report them to the facility manager.

\section{Building Description}

Office Building One is a six-story, 155,000 gross square foot office building that consists of an east and west wing and an underground basement. The building was constructed in 1973. The ground floor of the west wing includes the major mechanical equipment space that contains the building's main heating and cooling plants. The energy management control system's (EMCS's) host computer is located in the facility manager's office on the first floor of the west wing. Two energy-efficient chillers and the EMCS were installed in 1995. The fluorescent lighting for the building was 
upgraded to T-8 lamps with energy-efficient electronic ballasts in 1994. Primary heating is provided by two steam boilers with a hot water converter. Both steam and hot water are distributed. Five of the 15 air handlers use steam for heating; the remaining 10 use hot water. All under-window unit heaters use hot water for heating.

\section{Project Scope}

For the purpose of this study, only the energy-using equipment and systems will be investigated in detail. A site assessment tool combined with short-term diagnostic testing will be used for the investigation. The commissioning process will include the following major mechanical systems, equipment, and HVAC and lighting controls. (Note to reader: normally this list would include the brand name for each piece of equipment)

- Energy management control system

- Two centrifugal chillers

- One draw-through cooling tower

- Two low-pressure steam boilers and related hot water converter

- Pumping and piping system for the heating and cooling system

- 15 main air handlers

- Building exhaust fans

- One-Packaged Heat-Pumps-(not included in scope)

- Air distribution to spaces

- Domestic hot water

- Lighting control

The commissioning effort for this building will observe the various building systems' condition, operating strategies, and practices for the purpose of finding and implementing cost-effective improvements. The investigation will include testing individual pieces of equipment (as needed) and testing for how well equipment and system are integrated with each other. The project does not include implementing capital improvements. However, in the course of the investigation, any energyefficiency capital improvements that are thought to be effective will be offered as recommendations to the owner.

The investigation will also bring to the owner's attention any problems that might jeopardize the building's environmental quality. The project does not include implementation of solutions for the environmental quality problems. 
Roles and responsibilities

\begin{tabular}{|l|l|l|l|}
\hline \multicolumn{1}{|c|}{ Name } & \multicolumn{1}{|c|}{ Title or role } & $\begin{array}{c}\text { Phone: voice and } \\
\text { FAX numbers }\end{array}$ & \multicolumn{1}{|c|}{ Firm } \\
\hline Energy manager & $\begin{array}{l}\text { Energy manager/ } \\
\text { Project manager }\end{array}$ & & Office Building One \\
\hline Building manager & Facility manager & & Office Building One \\
\hline Supervisor & Facility supervisor & & Office Building One \\
\hline Technician & $\begin{array}{l}\text { Electrician I } \\
\text { (building engineer) }\end{array}$ & & Office Building One \\
\hline Commissioning expert & $\begin{array}{l}\text { Commissioning } \\
\text { provider }\end{array}$ & & $\begin{array}{l}\text { Commissioning for all } \\
\text { seasons }\end{array}$ \\
\hline Consultant & $\begin{array}{l}\text { Consulting design } \\
\text { engineer }\end{array}$ & & Constant Consulting \\
\hline Tester & Diagnostics specialist & & Testing for All Reasons \\
\hline Control contractor & Control technician I & & Controls Galore \\
\hline Utility & Utility representative & & Big City Electric \\
\hline
\end{tabular}

\section{Owner's staff}

- The energy manager, project manager, the owner's representative, oversees the overall implementation of the project and facilitates communication between the various parties.

- The building manager, facility manager, ensures the participation of building personnel and service contractors as needed, provides input into the investigation process, facilitates the implementation of improvements and the gathering of documentation, helps develop the training plan for the EMCS, and attends meetings as necessary.

- The supervisor, the facility supervisor, ensures personnel resources are available for the project, obtains manufacturer and service work documentation as needed, assists in problem-solving deficiency and improvement issues, helps develop the training plan for the new EMCS, and attends progress meetings.

- The technician, the on-site building engineer, gathers the building documentation, provides extensive input into the investigation process, assists with the installation and removal of diagnostic equipment and implementation of the identified commissioning improvements (as needed), helps develop the training plan for the EMCS, and attends meetings when necessary. The technician assists the commissioning provider with manual testing of equipment and systems as needed. 


\section{Contractors}

- The commissioning expert, the commissioning provider, develops and writes the commissioning plan, develops and administers the site investigation process, oversees the testing and data logging diagnostic process, develops the deficiency/improvements list (Master List), recommends the improvements based on findings, leads the weekly progress meetings, and writes the final report. He is responsible for all deliverables listed under the section of this plan titled "Product Deliverables".

- The consultant, the consulting design engineer, reviews and helps resolve design problems uncovered during the commissioning process.

- The tester, the diagnostic specialist, develops the diagnostic plan, installs the short-term monitoring equipment, analyzes and provides diagnostic results for the commissioning process, and provides savings analysis for the improvements.

- The controls contractor, the controls technician I, performs regularly scheduled preventive maintenance on the EMCS to match the needs of the retrocommissioning testing efforts, and is available to program changes, improvements, and trends as needed.

\section{Others}

- The utility representative is responsible for overseeing the project for the utility and providing support and monitoring equipment for the project as needed.

\section{Schedule for Primary Tasks}

An initial draft and final schedule are shown in Table G.1. The dates and tasks changed as the project progressed. Changes are shown in strikeout and italics. The task list gives a good indication of the general tasks and the order in which they will be undertaken.

As work progresses, the team will be notified of any schedule changes that may affect their specific tasks. 
Table G.1. Schedule of primary tasks

\begin{tabular}{|c|c|}
\hline Task & Estimated date \\
\hline Develop draft plan & Completed by April 15 \\
\hline Develop site-specific assessment tool and checklists. & Completed by May 3 \\
\hline Hold scoping meeting & April 27 \\
\hline Perform site investigation and staff interviews & May 6,7 , and 8 \\
\hline $\begin{array}{l}\text { Begin developing recommendations and decide on } \\
\text { improvements to implement from site investigation. } \\
\text { Summarize all findings and recommendations in a list } \\
\text { format }\end{array}$ & May 10 \\
\hline $\begin{array}{l}\text { Develop monitoring and trending plans and draft } \\
\text { functional performance tests (as needed) }\end{array}$ & Compete by May 17 May 22 \\
\hline $\begin{array}{l}\text { Install data loggers for first round of diagnostic } \\
\text { monitoring }\end{array}$ & $\begin{array}{l}\text { Week of May } 27, \text { start monitoring } \\
\text { May } 31\end{array}$ \\
\hline Remove data loggers & June 14 \\
\hline $\begin{array}{l}\text { Analyze data from trending, logging, and } \\
\text { assessment. Finalize the Master List of findings }\end{array}$ & Complete by dune-20 June 25 \\
\hline $\begin{array}{l}\text { Develop recommendations based on energy } \\
\text { calculations and decide on improvements to } \\
\text { implement from site investigation and diagnostic } \\
\text { monitoring }\end{array}$ & June-28June 30 \\
\hline Implement improvements & Complete by August 16 \\
\hline $\begin{array}{l}\text { Reinstall diagnostic equipment for second round of } \\
\text { diagnostic monitoring }\end{array}$ & $\begin{array}{l}\text { Dictated-date improvements-are } \\
\text { completed. August } 25\end{array}$ \\
\hline Remove diagnostic equipment & Same September 2 \\
\hline Make final improvements as needed & Complete by September 10 \\
\hline Train building staff about improvements (as needed) & October 5,6 \\
\hline Submit final report & Two weeks after implementation ends \\
\hline Project close out meeting & Last week in October \\
\hline
\end{tabular}




\section{Documentation}

Documentation for this project was requested prior to the development of this plan. Building staff will provide up-to-date and complete documentation according to the commissioning provider's request list. The list of requested documentation is attached.

\section{Investigation Scope and Methods}

This section of the plan briefly summarizes which systems, equipment, components, and functions will be investigated through the retrocommissioning process (see Table G.2), including the maintenance conditions and operating strategies. The investigation phase begins with an in-depth interview of building staff members to allow a thorough understanding of how and why the building is currently operated. Diagnostic methods are also discussed as part of this plan section. Some functional testing may be warranted during and after the data logging (short-term monitoring and trending) period to provide information about problems uncovered by the process.

Table G.2. Investigation summary

\begin{tabular}{|c|c|c|}
\hline Equipment or system & Component & Function \\
\hline EMCS & Lighting control & $\begin{array}{ll} & \text { Schedule (TOD) } \\
- & \text { Overrides } \\
- & \text { Staging }\end{array}$ \\
\hline EMCS & HVAC control & $\begin{array}{l}\text { Schedules (TOD) } \\
\text { Night setup and setback duct and } \\
\text { building static control } \\
\text { All energy-efficiency and cost-related } \\
\text { control strategies such as optimum } \\
\text { start, resets, load control, etc. Space } \\
\text { temperature setpoints } \\
\text { Heating/cooling control logic, plant } \\
\text { and system setpoints and reset } \\
\text { schedules } \\
\text { Lockouts and overrides Heating and } \\
\text { cooling change over strategies }\end{array}$ \\
\hline HVAC air handlers & Economizer & $\begin{array}{l}\text { Damper action and seal } \\
\text { Enthalpy control/dry bulb control } \\
\text { Minimum air requirements } \\
\text { Staging } \\
\text { Lockouts }\end{array}$ \\
\hline
\end{tabular}


Table G.2 (continued)

\begin{tabular}{|c|c|c|}
\hline Equipment or System & Component & Function \\
\hline HVAC & $\begin{array}{l}\text { A sample of terminal } \\
\text { units (to be determined) }\end{array}$ & $\begin{array}{l}\text { Observe: } \\
\text { Local thermostat control } \\
\text { Interface with EMCS } \\
\text { Damper/vane operation (VAV) }\end{array}$ \\
\hline HVAG & $\begin{array}{l}\text { Packaged Heat Pump } \\
\text { Removed from scope }\end{array}$ & 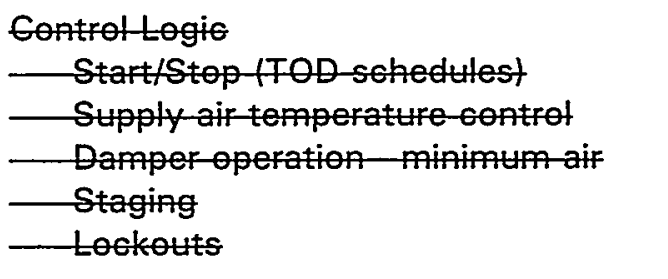 \\
\hline HVAC & Cooling tower & $\begin{array}{l}\text { Capacity as time-and conditions permit- } \\
\text { Fan control-stop/start } \\
\text { Control logic (staging of fan and } \\
\text { pump) } \\
\text { Pump control-stop/start } \\
\text { Pump flows }\end{array}$ \\
\hline HVAC & Chillers and boilers & $\begin{array}{l}\text { Integral controls } \\
\text { Reset capabilities } \\
\text { Lockouts } \\
\text { Interface with EMCS control logic } \\
\text { Efficiency and capacity as conditions } \\
\text { permit } \\
\text { Staging } \\
\text { Pump control-stop/start } \\
\text { Pump flows }\end{array}$ \\
\hline HVAC & Hot water converter & $\begin{array}{l}\text { Condition } \\
\text { Flows }\end{array}$ \\
\hline Domestic hot water & Control & $\begin{array}{c}\text { Temperatures } \\
\text { Pumps }\end{array}$ \\
\hline
\end{tabular}

A sample of EMCS sensors related to the plant and system will be checked for calibration, including the humidity sensors and outside air sensors, as part of the investigation.

\section{Investigation Phase-Diagnostic Testing Methods}

\section{Short-term diagnostic}

Short-term diagnostics for this project will use portable data loggers to measure temperature, humidity, pressures, current, and flows over time. The data loggers will be installed for 1 to 2 weeks. The information gathered during this time frame will be 
analyzed to determine which systems, equipment, and controls are not functioning properly.

The necessary improvements (operation adjustments, maintenance work, and repairs) will be based on the commissioning site investigation and the diagnostic findings (see below, "Prioritizing Improvements for Implementation").

The data loggers will then be reinstalled (in selected areas) in order to determine the effect of the adjustments and repairs on performance.

Note: The diagnostic plan should be developed after completion of the siteassessment.

\section{EMCS trend logs}

Wherever possible, the trend log capability of the EMCS will be used to document system performance. Detailed requirements for the trend logs will be developed as part of the site investigation and short-term diagnostic plan, in cooperation with the testing specialist, controls contractor, and operating engineer.

\section{Functional performance tests}

Functional performance tests may be performed as needed as part of the diagnostic monitoring and trending to determine how well the equipment is performing and help pinpoint problems and causes. Manual functional testing may be performed using hand-held test instruments on selected equipment that is not part of the monitoring and trending plans.

The completed diagnostic test plans (monitoring and trending) and results, along with the completed functional performance tests, become part of the final report to the owner.

\section{Prioritizing Improvements for Implementation}

Once the site assessment interview and diagnostic testing are completed, the commissioning provider will summarize the findings on the Master List and submit it to the owner's team for review. For this project, the Master List of potential improvements should address the following categories of information:

\begin{tabular}{|l|l|c|c|c|}
\hline Item number & $\begin{array}{c}\text { Equipment name } \\
\text { and ID \# }\end{array}$ & $\begin{array}{c}\text { Finding } \\
\text { description and } \\
\text { type }\end{array}$ & $\begin{array}{c}\text { Recommended } \\
\text { solution or action }\end{array}$ & $\begin{array}{c}\text { Status of } \\
\text { implementation }\end{array}$ \\
\hline & & & & \\
\hline
\end{tabular}

* The type of problem or finding may be categorized as " $\mathrm{O}$ " operation, " $\mathrm{M}$ " Maintenance, or " $D$ " design. 
After the owner reviews the Master List, the commissioning provider will guide the owner in selecting the most cost-effective improvements that meet the project's objectives. For this project, the main focus is on the first objective, to obtain costeffective energy savings from optimizing how the building's energy-using systems are operated and maintained. The Commissioning Provider, using the information gathered from the site assessment process and diagnostic testing, will analyze the data and perform appropriate engineering calculations to estimate the energy savings for each of the most significant findings. The owner will make the final decision on which improvements to implement.

\section{Implementation Phase}

The commissioning provider will plan and coordinate the implementation process. For the most part, implementation of the selected improvements will be completed by in-house staff. The controls contractor will be hired as needed to make programming changes that are beyond the normal responsibilities of the in-house staff. Two in-house staff members will be assigned and allotted 40 hours each to implement the improvements.

\section{Project Handoff}

For the commissioning provider, project handoff includes the following tasks:

- writing and submitting a final report for approval by the owner;

- developing a recommended list of building-specific, energy-efficient capital improvements for further investigation; and

- developing a recommended recommissioning schedule as part of the regular preventive maintenance program.

A project hand-off meeting will be scheduled, if needed, to discuss the main project deliverables and next steps. 


\section{Sample Site Assessment Forms}

Appendix $\mathrm{H}$ contains sample site-assessment forms. Assessment forms help guide the interview process with building staff that occurs during the investigation phase of the project. Site assessment forms are developed for each piece of equipment and each system that is selected for retrocommissioning. The forms may address either operation or maintenance issues, or both, depending on the scope of the project. The site assessment is an information-gathering exercise. Minor repairs and simple improvements may be implemented during the assessment; however, the major problem solving and improvement recommendations generally occur at the end of the investigation phase, after all the information and data are analyzed. 


\section{Sample Site-Assessment Form (Interview)}

\section{General O\&M Questions}

Has your heating system always met load? $\square$ Yes $\square$ No

Under what conditions has your heating system not met load?

What was the solution to this problem:

Has your cooling system always met load? $\square$ Yes $\square$ No

Under what conditions has your cooling system not met load?

What was the solution to this problem:

Do you feel you have any HVAC equipment that is undersized? $\square$ Yes $\square$ No

If yes, explain:

How do you compensate for the undersizing?

Do you feel you have any HVAC equipment that is oversized? $\square$ Yes $\square$ No

If yes, explain:

How do you compensate for the oversizing?

Is the building mechanical equipment (fans, pumps, etc.) scheduled to start up simultaneously, or is the startup staged?

What HVAC adjustments do you make to unoccupied areas or spaces le.g., turn off HVAC, adjust thermostat to minimum heating and cooling, close off diffuser)?

In your opinion, is the building HVAC system well balanced? $\square$ Yes $\square$ No

If no, explain:

Explain the method of humidification for the building:

Are there any problems with the humidification method (explain)? $\square$ Yes $\square$ No If yes, explain: 
Explain the method of dehumidification for the building:

Are there any problems with the dehumidification method (explain)? $\square$ Yes $\square$ No

If yes, explain:

From what areas in the building do you receive the most complaints (explain nature of complaints)?

What is your worst building problem and how do you deal with it?

Notes, comments, and observations 


\section{Sample Site Assessment Form for Domestic Hot Water}

What is the temperature setpoint for each of the building's hot water heaters?

\begin{tabular}{|l|l|l|l|}
\hline Heater ID $\cdot$ & Area served & Temperature setting & Reason for setting \\
\hline \hline & & & \\
\hline & & & \\
\hline & & & \\
\hline & & & \\
\hline & & & \\
\hline & & & \\
\hline & & & \\
\hline & & & \\
\hline
\end{tabular}

Explain method of domestic hot water control:

If hot water is preheated, explain method:

Do the recirculating pumps run continuously?

Notes, comments, and observations

(Summarize deficiencies and possible improvements on Master List) 


\section{Sample Pump Assessment Forms}

\section{Pump Control Questions}

Circle or explain what function the pump serves:

Condenser water Chilled water Secondary chilled water Heating water Secondary heating water

Other:

\section{Pump ID \#:}

What causes the pump to start initially?

What causes the pump to cycle?

How is capacity controlled (VFD, etc.)?

(If a VFD is used, attach VFD assessment form to the appropriate pump form)

If applicable, what is the differential pressure control point?

If there is a lead/lag strategy, explain:

If pumps are staged, explain:

Notes, comments, and observations

Circle or explain what function the pump serves:

Condenser water Chilled water Secondary chilled water Heating water Secondary heating water

Other:

\section{Pump ID \#:}

What causes the pump to start initially?

What causes the pump to cycle?

How is capacity controlled (VFD, etc.)?

(If a VFD is used, attach VFD assessment form to the appropriate pump form) 
If applicable, what is the differential pressure control point?

If there is a lead/lag strategy, explain:

If pumps are staged, explain:

Notes, comments, and observations

(Summarize deficiencies and possible improvements on Master List) 


\section{Pump Nameplate Information}

Use N/A for not applicable and N/O for not obtainable or available.

\begin{tabular}{|c|c|c|c|c|}
\hline $\begin{array}{l}\text { Pump function: (heating } \\
\text { water, condenser, etc..) }\end{array}$ & & & & \\
\hline Pump ID or number & & & & \\
\hline Pump manufacturer & & & & \\
\hline Model number & & & & \\
\hline Serial number & & & & \\
\hline Age & & & & \\
\hline Impeller size & & & & \\
\hline Head pressure & & & & \\
\hline Suction pressure & & & & \\
\hline Discharge pressure & & & & \\
\hline GPM & & & & \\
\hline Motor manufacturer & & & & \\
\hline Motor model \# & & & & \\
\hline Phase & & & & \\
\hline Volts phase to phase & $\begin{array}{l}\text { Nameplate: } \\
\text { Measured: }\end{array}$ & $\begin{array}{l}\text { Nameplate: } \\
\text { Measured: }\end{array}$ & $\begin{array}{l}\text { Nameplate: } \\
\text { Measured: }\end{array}$ & $\begin{array}{l}\text { Nameplate: } \\
\text { Measured: }\end{array}$ \\
\hline Volts phase to ground & Measured: & Measured: & Measured: & Measured: \\
\hline RLA each phase & $\begin{array}{l}\text { Nameplate: } \\
\text { Measured: }\end{array}$ & $\begin{array}{l}\text { Nameplate: } \\
\text { Measured: }\end{array}$ & $\begin{array}{l}\text { Nameplate: } \\
\text { Measured: }\end{array}$ & $\begin{array}{l}\text { Nameplate: } \\
\text { Measured: }\end{array}$ \\
\hline kW & Measured: & Measured: & Measured: & Measured: \\
\hline Power factor & Measured: & Measured: & Measured: & Measured: \\
\hline HP & & & & \\
\hline RPM & & & & \\
\hline
\end{tabular}

Notes, comments, and observations 


\section{Pump Maintenance Checklist}

Check if okay; enter comment number if deficient. Document comments by number in form provided below checklist. Use N/A for not applicable and N/O for not obtainable or available.

\begin{tabular}{|c|c|c|c|c|}
\hline Pump ID & & & & \\
\hline \multicolumn{5}{|l|}{$\begin{array}{l}\text { General condition good (clean and } \\
\text { appear well maintained) }\end{array}$} \\
\hline \multicolumn{5}{|l|}{ No unusual noise or vibration } \\
\hline \multicolumn{5}{|l|}{ No water leaks } \\
\hline \multicolumn{5}{|l|}{ Thermometers on supply and return. } \\
\hline $\begin{array}{l}\text { Pressure gauges installed across } \\
\text { pumps and functioning (if so, record } \\
\text { pressures) }\end{array}$ & $\begin{array}{l}\text { Suction: } \\
\text { Discharge: }\end{array}$ & $\begin{array}{l}\text { Suction: } \\
\text { Discharge: }\end{array}$ & $\begin{array}{l}\text { Suction: } \\
\text { Discharge: }\end{array}$ & $\begin{array}{l}\text { Suction: } \\
\text { Discharge: }\end{array}$ \\
\hline \multicolumn{5}{|l|}{ Pump rotation correct } \\
\hline \multicolumn{5}{|l|}{ Properly balanced } \\
\hline \multicolumn{5}{|l|}{$\begin{array}{l}\text { Strainers in place and clean? State } \\
\text { when strainers were last cleaned }\end{array}$} \\
\hline \multicolumn{5}{|l|}{ Piping properly insulated } \\
\hline \multicolumn{5}{|l|}{ Piping generally in good condition } \\
\hline \multicolumn{5}{|l|}{ Valves in good condition - no leaks } \\
\hline $\begin{array}{l}\text { Water treatment in place and } \\
\text { operating }\end{array}$ & & & & \\
\hline
\end{tabular}

\begin{tabular}{l|l} 
Number & Comment \\
\hline & \\
\hline & \\
\hline & \\
\hline & \\
\hline & \\
\hline
\end{tabular}

Summarize all deficiencies and possible improvements on the Master List. 


\section{Appendix I}

\section{Sample Master List}

Appendix I contains a sample "Master List of Deficiencies and Improvements," also called the "Master List." This list summarizes the findings from the investigation phase of the project and is a primary product or deliverable resulting from the retrocommissioning process. 


\section{Sample Master List of Deficiencies and Potential Improvements}

\begin{tabular}{|c|c|c|c|c|c|}
\hline $\begin{array}{c}\text { Item } \\
\#\end{array}$ & $\begin{array}{l}{ }^{*} \text { Equipment or } \\
\text { system ID }\end{array}$ & Description of finding & $\begin{array}{c}\text { Recommended } \\
\text { improvement }\end{array}$ & Type & Status \\
\hline 1 & $\begin{array}{l}\text { All plant } \\
\text { equipment }\end{array}$ & $\begin{array}{l}\text { Manual startup and } \\
\text { shutdown of boilers, } \\
\text { chillers, pumps. } \\
\text { Automatic scheduling } \\
\text { not incorporated }\end{array}$ & $\begin{array}{l}\text { Include and implement } \\
\text { automatic scheduling } \\
\text { for plant equipment } \\
\text { using optimum start; } \\
\text { incorporate setup and } \\
\text { setback strategies }\end{array}$ & $\bar{O}$ & $\begin{array}{l}\text { Done. Testing for } \\
\text { cooling equipment } \\
\text { deferred until } \\
\text { cooling season }\end{array}$ \\
\hline 2 & Boiler control & $\begin{array}{l}\text { Control strategy for loss } \\
\text { of boiler not } \\
\text { programmed }\end{array}$ & $\begin{array}{l}\text { Add programming to } \\
\text { allow automatic startup } \\
\text { of } 2 \text { nd boiler on loss of } \\
1 \text { st boiler }\end{array}$ & $\overline{0}$ & Done \\
\hline$\overline{3}$ & Chillers 1 and 2 & $\begin{array}{l}\text { Lacks interface with } \\
\text { EMCS (see also \#2) }\end{array}$ & $\begin{array}{l}\text { At minimum, allow } \\
\text { EMCS to enable and } \\
\text { disable the chiller and } \\
\text { add monitoring points } \\
\text { for water temperatures } \\
\text { and run status }\end{array}$ & $\overline{0}$ & $\begin{array}{l}\text { Done. Retest } \\
\text { deferred until } \\
\text { cooling season }\end{array}$ \\
\hline 4 & Chillers 1 and 2 & $\begin{array}{l}\text { Chilled water reset } \\
\text { capability not used }\end{array}$ & \begin{tabular}{|l|} 
At minimum, allow the \\
chiller's integral controls \\
to reset chilled water \\
temperature (see \\
manufacturer's \\
instructions)
\end{tabular} & $\overline{0}$ & $\begin{array}{l}\text { Reset installed } \\
\text { through EMCS } \\
\text { system }\end{array}$ \\
\hline 5 & Chillers 1 and 2 & Energy tracking & $\begin{array}{l}\text { Add points to EMCS to } \\
\text { allow energy and } \\
\text { demand tracking for } \\
\text { both chillers }\end{array}$ & $\mathrm{O} / \mathrm{M}$ & Done \\
\hline 6 & Chillers 1 and 2 & $\begin{array}{l}\text { Chillers do not operate } \\
\text { in parallel as was } \\
\text { original design intent }\end{array}$ & \begin{tabular}{|l|} 
Have design engineer \\
and chiller maker review \\
present chilled water \\
system. Request a \\
proposal for design \\
changes necessary to \\
allow chillers to stage \\
as a lead/lag system \\
\end{tabular} & $\bar{D}$ & $\begin{array}{l}\text { Design referral } \\
\text { Design review in } \\
\text { process }\end{array}$ \\
\hline 7 & Chiller 1 and 2 & High demand on startup & $\begin{array}{l}\text { Consider employing soft } \\
\text { start through EMCS or } \\
\text { integral controls }\end{array}$ & 0 & $\begin{array}{l}\text { Soft start added to } \\
\text { chiller startup }\end{array}$ \\
\hline 8 & EMCS & Trending not installed & $\begin{array}{l}\text { Add trending } \\
\text { capabilities to EMCS to } \\
\text { improve building staff's } \\
\text { troubleshooting abilities }\end{array}$ & $\bar{O} / \mathrm{M}$ & Done \\
\hline 9 & $\begin{array}{l}\text { Heat/cool } \\
\text { changeover }\end{array}$ & $\begin{array}{l}\text { Manual changeover } \\
\text { between heating and } \\
\text { cooling }\end{array}$ & $\begin{array}{l}\text { Add points needed to } \\
\text { incorporate automatic } \\
\text { changeover strategy }\end{array}$ & 0 & Done \\
\hline
\end{tabular}




\begin{tabular}{|c|c|c|c|c|c|}
\hline \begin{tabular}{|c|} 
Item \\
$\#$ \\
\end{tabular} & $\begin{array}{l}{ }^{*} \text { Equipment or } \\
\text { system ID }\end{array}$ & Description of finding & $\begin{array}{c}\text { Recommended } \\
\text { improvement }\end{array}$ & Type & Status \\
\hline 10 & $\begin{array}{l}\text { Chilled water } \\
\text { pump, P-1 }\end{array}$ & $\begin{array}{l}\text { Pump is possibly } \\
\text { oversized } \\
\text { Piping is possibly } \\
\text { undersized }\end{array}$ & $\begin{array}{l}\text { Investigate sizing of the } \\
\text { pump. Check amps } \\
\text { against nameplate } \\
\text { during full load } \\
\text { conditions. Review } \\
\text { piping }\end{array}$ & $\bar{D}$ & $\begin{array}{l}\text { Pump review done. } \\
\text { Piping design } \\
\text { referral } \\
\text { Review in process }\end{array}$ \\
\hline 11 & $\begin{array}{l}\text { Condensate } \\
\text { pump inside } \\
\text { AC-1 }\end{array}$ & $\begin{array}{l}\text { Pump located inside of } \\
\text { AC- } 1 \text { may cause high } \\
\text { discharge air } \\
\text { temperatures }\end{array}$ & $\begin{array}{l}\text { Investigate relocating } \\
\text { pump or venting it to } \\
\text { mechanical room. (Does } \\
\text { the pump run } \\
\text { continuously?) Ref. } \\
11 / 14 / 96 \text { meeting fax } \\
\end{array}$ & $\bar{M}$ & $\begin{array}{l}\text { Insulated for } \\
\text { temporary solution }\end{array}$ \\
\hline 12 & $\begin{array}{l}\text { Cooling tower } \\
\text { fans }\end{array}$ & $\begin{array}{l}\text { Diagnostics show tower } \\
\text { cycles on primary fan } \\
\text { only. Pony motor not } \\
\text { working }\end{array}$ & $\begin{array}{l}\text { Troubleshoot cooling } \\
\text { tower to determine } \\
\text { staging problem Repair } \\
\text { so pony motor cycles as } \\
1 \text { st stage }\end{array}$ & $\mathrm{M} / \mathrm{O}$ & Done \\
\hline 13 & $\begin{array}{l}\text { Cooling tower } \\
\text { control }\end{array}$ & $\begin{array}{l}\text { Integral chiller control } \\
\text { for staging cooling } \\
\text { tower fans not used } \\
\text { Temperature bulb for } \\
\text { sump may be poorly } \\
\text { located }\end{array}$ & $\begin{array}{l}\text { Investigate using the } \\
\text { chiller capability of } \\
\text { staging the cooling } \\
\text { tower fans based on } \\
\text { condenser differential } \\
\text { refrigerant pressure. If } \\
\text { present strategy is kept, } \\
\text { relocate temperature } \\
\text { bulb lower in pan and } \\
\text { closer to outlet }\end{array}$ & 0 & $\begin{array}{l}\text { Delta P Strategy } \\
\text { not appropriate. } \\
\text { Staging from sump } \\
\text { temperature is a } \\
\text { better method. Bulb } \\
\text { relocated }\end{array}$ \\
\hline 14 & $\begin{array}{l}\text { Cooling tower } \\
\text { 3-way valve }\end{array}$ & $\begin{array}{l}\text { According to functional } \\
\text { tests, the valve doesn't } \\
\text { modulate to maintain } \\
\text { condenser water } \\
\text { temperature as it should }\end{array}$ & $\begin{array}{l}\text { Troubleshoot problem } \\
\text { and repair so valve } \\
\text { modulates as designed }\end{array}$ & D/M/O & $\begin{array}{l}\text { Repaired. This will } \\
\text { be rechecked as } \\
\text { part of the design } \\
\text { review and PM } \\
\text { recommissioning }\end{array}$ \\
\hline 15 & Heating system & $\begin{array}{l}\text { Data show heating } \\
\text { water supply } \\
\text { temperatures between } \\
80 \text { and } 90^{\circ} \mathrm{F}\end{array}$ & $\begin{array}{l}\text { Investigate. Normally, } \\
\text { heating water } \\
\text { temperatures are } \\
\text { between } 140 \text { and } \\
180^{\circ} \mathrm{F}\end{array}$ & 0 & $\begin{array}{l}\text { Resolved with new } \\
\text { reset schedule }\end{array}$ \\
\hline 16 & $\begin{array}{l}\text { Plant } \\
\text { instrumentation }\end{array}$ & $\begin{array}{l}\text { Pressure and temp } \\
\text { gages missing from } \\
\text { plant piping }\end{array}$ & $\begin{array}{l}\text { Install pressure and } \\
\text { temperature gages on } \\
\text { chiller, boiler, and } \\
\text { pumps as needed to } \\
\text { facilitate maintenance } \\
\text { and troubleshooting }\end{array}$ & $\bar{M}$ & $\begin{array}{l}\text { As time and budget } \\
\text { permits for building } \\
\text { staff }\end{array}$ \\
\hline 17 & $\begin{array}{l}\text { East primary air } \\
\text { unit } A C-1\end{array}$ & $\begin{array}{l}\text { Data show inconsistent } \\
\text { control of supply and } \\
\text { mixed air. Steam valve } \\
\text { erratic during temps } \\
\text { below } 35^{\circ} \mathrm{F}\end{array}$ & Correct through EMCS & 0 & Done \\
\hline
\end{tabular}




\begin{tabular}{|c|c|c|c|c|c|}
\hline \begin{tabular}{|c|} 
Item \\
$\#$ \\
\end{tabular} & $\begin{array}{l}\text { *Equipment or } \\
\text { system ID }\end{array}$ & Description of finding & $\begin{array}{c}\text { Recommended } \\
\text { improvement }\end{array}$ & Type & Status \\
\hline 18 & $\begin{array}{l}\text { West primary } \\
\text { air unit } A C-12\end{array}$ & \begin{tabular}{|l|} 
Data show erratic \\
control of supply air and \\
no drop in supply air \\
temperature when \\
chillers are on \\
\end{tabular} & $\begin{array}{l}\text { Investigate. Remonitor } \\
\text { during second round of } \\
\text { diagnostics by } \\
\text { measuring mixed air } \\
\text { temperature also } \\
\end{array}$ & $\overline{0}$ & $\begin{array}{l}\text { Retest in cooling } \\
\text { season }\end{array}$ \\
\hline 19 & $\begin{array}{l}\mathrm{AC}-13 \\
\text { (multizone unit) }\end{array}$ & \begin{tabular}{|l|} 
Data show wide swings \\
in hot and cold deck \\
temperatures, resulting \\
in poor control of space \\
temperatures
\end{tabular} & \begin{tabular}{|l|} 
Improve control through \\
EMCS. Investigate \\
damper and valve \\
functions
\end{tabular} & $\mathrm{O} / \mathrm{M}$ & $\begin{array}{l}\text { Done. Retest } \\
\text { shows correction } \\
\text { successful }\end{array}$ \\
\hline 20 & $\begin{array}{l}\mathrm{AC}-13 \\
\text { (multizone unit) }\end{array}$ & $\begin{array}{l}\text { Data show poor } \\
\text { economizer control }\end{array}$ & $\begin{array}{l}\text { Improve economizer } \\
\text { control through EMCS. } \\
\text { Investigate damper } \\
\text { function. Consider } \\
\text { enthalpy control using } \\
\text { EMCS } \\
\end{array}$ & $\mathrm{O} / \mathrm{M}$ & Same as 18 \\
\hline 21 & All air handlers & $\begin{array}{l}\text { TOD scheduling not } \\
\text { used }\end{array}$ & $\begin{array}{l}\text { Include and implement } \\
\text { TOD scheduling. } \\
\text { Stagger start time at } \\
\text { occupied target and } \\
\text { following power loss }\end{array}$ & $\overline{0}$ & $\begin{array}{l}\text { Scheduled from } \\
\text { plant equipment } \\
\text { through EMCS }\end{array}$ \\
\hline 22 & $\begin{array}{l}\text { Air handler } \\
\text { AC-1 OSA } \\
\text { preheater }\end{array}$ & \begin{tabular}{|l|} 
Preheat coil is not \\
functioning properly. \\
Present averaging bulb \\
sensor (input for \\
controlling the steam \\
valve) was found to \\
have $70 \%$ of its sensing \\
element outside of the \\
unit
\end{tabular} & \begin{tabular}{|l|} 
Relocate averaging bulb \\
sensing element to read \\
temperature of air \\
stream. Ensure freeze \\
protection operates to \\
shut OSA damper when \\
OSA conditions dictate. \\
Check control strategy \\
through JC system (see \\
notes below)
\end{tabular} & $\mathrm{M} / \mathrm{O}$ & $\begin{array}{l}\text { Done } \\
\text { Averaging bulb } \\
\text { relocated }\end{array}$ \\
\hline 23 & $\begin{array}{l}\text { Air handlers } \\
A C-11 \text { through } \\
18\end{array}$ & $\begin{array}{l}\text { OSA dampers not } \\
\text { controlled to take } \\
\text { advantage of } \\
\text { economizer capability }\end{array}$ & $\begin{array}{l}\text { Program system and } \\
\text { add humidity sensors } \\
\text { (outside and inside) to } \\
\text { employ enthalpy control } \\
\text { for economizing. At } \\
\text { minimum use dry bulb } \\
\text { control }\end{array}$ & 0 & $\begin{array}{l}\text { Done } \\
11,13,15,18 \\
\text { fine-tuned }\end{array}$ \\
\hline 24 & $A C-15$ and 18 & $\begin{array}{l}\text { Data show } A C-15 \text { OSA } \\
\text { damper always closed } \\
\text { and } A C-18 \text { opening } \\
\text { partially some of the } \\
\text { time }\end{array}$ & $\begin{array}{l}\text { Improve economizer } \\
\text { control with EMCS } \\
\text { program and investigate } \\
\text { damper function (see } \\
\text { also \#22) }\end{array}$ & $\mathrm{O} / \mathrm{M}$ & $\begin{array}{l}\text { Same } \\
\text { Done }\end{array}$ \\
\hline
\end{tabular}




\begin{tabular}{|c|c|c|c|c|c|}
\hline $\begin{array}{c}\text { Item } \\
\#\end{array}$ & $\begin{array}{l}{ }^{*} \text { Equipment or } \\
\text { system ID }\end{array}$ & Description of finding & $\begin{array}{l}\text { Recommended } \\
\text { improvement }\end{array}$ & Type & Status \\
\hline 25 & $\begin{array}{l}\text { Air handlers } \\
\text { AC- } 4,5 \text { and } 10\end{array}$ & No air side economizing & $\begin{array}{l}\text { Add actuators to OSA } \\
\text { and RA dampers along } \\
\text { with EMCS points and } \\
\text { program to take } \\
\text { advantage of } \\
\text { economizer function }\end{array}$ & $\mathrm{O} / \mathrm{D}$ & $\begin{array}{l}\text { Ten are done } \\
\text { Others dependent } \\
\text { on AC- } 1 \text {. Design } \\
\text { review in progress }\end{array}$ \\
\hline 26 & $\begin{array}{l}\text { VAV Operation } \\
\text { and control for } \\
\text { west conf. } \\
\text { space }\end{array}$ & $\begin{array}{l}\text { VAV boxes are secured } \\
\text { open and the VFD is } \\
\text { circumvented. Test } \\
\text { need for duct heaters }\end{array}$ & $\begin{array}{l}\text { Consider reinstituting } \\
\text { the VAV system using } \\
\text { the VFD. Repair reheat } \\
\text { if they are needed }\end{array}$ & $\mathrm{M} / \mathrm{O}$ & $\begin{array}{l}\text { Done. VFD } \\
\text { working. Reheats } \\
\text { not needed }\end{array}$ \\
\hline 27 & $\begin{array}{l}\text { OSA } \\
\text { temperature } \\
\text { sensor }\end{array}$ & Calibration issue & \begin{tabular}{l|} 
Check calibration of \\
OSA temperature \\
sensor, relocate, and \\
shield properly if needed
\end{tabular} & $\mathrm{M} / \mathrm{O}$ & $\begin{array}{l}\text { Relocated to roof } \\
\text { using weather } \\
\text { resistant type } \\
\text { sensor and } \\
\text { shieiding. Done }\end{array}$ \\
\hline 28 & EMCS & $\begin{array}{l}\text { Facility staff did not } \\
\text { receive adequate } \\
\text { training on EMCS }\end{array}$ & \begin{tabular}{|l|} 
Provide 8040 hours of \\
training to facility staff \\
using original \\
specification. Train \\
building staff to present \\
data in graphical format
\end{tabular} & $\bar{O}$ & $\begin{array}{l}40 \text { hours of training } \\
\text { specified and } \\
\text { complete }\end{array}$ \\
\hline 29 & $\begin{array}{l}\text { Domestic hot } \\
\text { water }\end{array}$ & $\begin{array}{l}\text { High water temperature } \\
\left(140^{\circ} \mathrm{F}\right)\end{array}$ & $\begin{array}{l}\text { Lower domestic hot } \\
\text { water to } 110^{\circ} \mathrm{F} \text { for } \\
\text { restrooms and } 120^{\circ} \mathrm{F} \\
\text { for showers. Kitchen } \\
\text { needs for hot water } \\
\text { have priority over this } \\
\text { strategy }\end{array}$ & 0 & $\begin{array}{l}\text { Presently, higher } \\
\text { temperature needed } \\
\text { for kitchen. Point- } \\
\text { of-use water heater } \\
\text { to be installed in } \\
\text { kitchen }\end{array}$ \\
\hline
\end{tabular}


Appendix J

\section{Sample Diagnostic Monitoring and Trending Plans}

Appendix $\mathrm{J}$ contains two pages of a sample data logger plan for a typical commercial office building. The data logger plan lists all of the data loggers for the project, their location, and what information they are recording. Appendix $J$ also contains a sample energy management control system (EMCS) trending plan for implementation by either building staff or the controls contractor. 


\section{Data Logger Plan for Short-Term Diagnostic Monitoring}

\section{Project Name:}

Brand name of data loggers:

Run-time parameters:

Start date:

Start time:

Stop date:

Stop time:

Duration:

Sampling frequency:

Storage frequency:

Total loggers:

Total points:

Each logger has four separate modules. Each module can be programmed separately to gather data on temperature, pressure, or current. Following are the first two pages of the logger plan for Building One.

\section{Logger 1:}

\begin{tabular}{lllllll}
\hline $\begin{array}{l}\text { Equipment } \\
\text { name }\end{array}$ & Point name & Measurement & Type module & Units & Min. & Max. \\
\hline Chiller-1 & $\begin{array}{l}\text { Leaving chill. } \\
\text { water }\end{array}$ & Water & Temp. & ${ }^{\circ} \mathrm{F}$ & 32 & 212 \\
\hline Chiller-1 & $\begin{array}{l}\text { Entering chill. } \\
\text { water }\end{array}$ & Water & Temp. & ${ }^{\circ} \mathrm{F}$ & 32 & 212 \\
\hline Chiller-1 & Chil. Pump-1 & Current & $400 \mathrm{mV} \mathrm{AC}$ & Amps & 0 & 0 \\
\hline Chiller-1 & Cond. Pump-1 & Current & $400 \mathrm{mV} \mathrm{AC}$ & Amps & 0 & 0 \\
\hline
\end{tabular}

Logger 2:

\begin{tabular}{lllllll}
\hline $\begin{array}{l}\text { Equipment } \\
\text { name }\end{array}$ & Point name & Measurement & Type module & Units & Min. & Max. \\
\hline Chiller-2 & $\begin{array}{l}\text { Leaving chill. } \\
\text { water }\end{array}$ & Water & Temp. & ${ }^{\circ} \mathrm{F}$ & 32 & 212 \\
\hline Chiller-2 & $\begin{array}{l}\text { Entering chill. } \\
\text { water }\end{array}$ & Water & Temp. & ${ }^{\circ} \mathrm{F}$ & 32 & 212 \\
\hline Chiller-2 & Chil. Pump-2 & Current & $400 \mathrm{mV} \mathrm{AC}$ & Amps & 0 & 0 \\
\hline Chiller-2 & Cond. Pump-2 & Current & $400 \mathrm{mV} \mathrm{AC}$ & Amps & 0 & 0 \\
\hline
\end{tabular}


Logger 3:

\begin{tabular}{lllllll}
\hline $\begin{array}{l}\text { Equipment } \\
\text { name }\end{array}$ & Point name & Measurement & Type module & Units & Min. & Max. \\
\hline AC-13 & Hot deck & Temperature & Temp. & ${ }^{\circ} \mathrm{F}$ & 32 & 212 \\
\hline AC-13 & Cold deck & Temperature & Temp. & ${ }^{\circ} \mathrm{F}$ & 32 & 212 \\
\hline AC-13 & Mixed air & Temperature & Temp. & ${ }^{\circ} \mathrm{F}$ & 32 & 212 \\
\hline AC-13 & Return air & Temperature & Temp. & ${ }^{\circ} \mathrm{F}$ & 32 & 212 \\
\hline
\end{tabular}

\section{Logger 4:}

\begin{tabular}{lllllll}
\hline $\begin{array}{l}\text { Equipment } \\
\text { name }\end{array}$ & Point name & Measurement & Type module & Units & Min. & Max. \\
\hline $\begin{array}{l}\text { Cooling } \\
\text { tower }\end{array}$ & $\begin{array}{l}\text { Primary fan } \\
\text { motor }\end{array}$ & Current & $400 \mathrm{mV}$ AC & Amps & 0 & 0 \\
\hline $\begin{array}{l}\text { Cooling } \\
\text { tower }\end{array}$ & Pony motor & Current & $400 \mathrm{mV} \mathrm{AC}$ & Amps & 0 & 0 \\
\hline $\begin{array}{l}\text { Cooling } \\
\text { tower }\end{array}$ & Sump & Water & Temp. & ${ }^{\circ} \mathrm{F}$ & 32 & 212 \\
\hline
\end{tabular}

\section{Logger 5:}

\begin{tabular}{lllllll}
\hline $\begin{array}{l}\text { Equipment } \\
\text { name }\end{array}$ & Point name & Measurement & Type module & Units & Min. & Max. \\
\hline $\begin{array}{l}\text { Ambient } \\
\text { outside }\end{array}$ & Outside air temp. & Temperature & Temp. & ${ }^{\circ} \mathrm{F}$ & 32 & 212 \\
\hline $\begin{array}{l}\text { Ambient } \\
\text { outside }\end{array}$ & Outside humidity & Relative humidity & Humidity & RH & 0 & 100 \\
\hline
\end{tabular}

\section{Logger 6}

\begin{tabular}{lllllll}
\hline $\begin{array}{l}\text { Equipment } \\
\text { name }\end{array}$ & Point name & Measurement & Type module & Units & Min. & Max. \\
\hline Boiler-1 & Pump & Current & $400 \mathrm{mV}$ AC & Amps & 0 & 0 \\
\hline Boiler-2 & Pump & Current & $400 \mathrm{mV}$ AC & Amps & 0 & 0 \\
\hline Boiler-1 & Forced draft fan & Current & $400 \mathrm{mV} \mathrm{AC}$ & Amps & 0 & 0 \\
\hline Boiler-2 & Forced draft fan & Current & $400 \mathrm{mV} \mathrm{AC}$ & Amps & 0 & 0 \\
\hline
\end{tabular}




\section{Sample EMCS Trending Plan}

The building staff is responsible for entering and initiating the trends using the building's EMCS according to this plan. Calibration of critical sensors should be completed no more than two weeks prior to initiating trends. Trending and the shortterm data logging are done simultaneously. The trend data are then compared with the data gathered by the portable data loggers to determine whether the EMCS is working correctly. Trend data are also used to augment the short-term diagnostics for verifying sequences of operation and schedules. This trend plan will be used both during preimplementation of the improvements and during post- implementation. Any changes to the plan for post-implementation are noted in italics. The following tables outline the trend plan for Office Building One.

Plant equipment

\begin{tabular}{|l|c|}
\hline \multicolumn{1}{|c|}{ Description of trend point } & $\begin{array}{c}\text { Number of points per } \\
\text { trend }\end{array}$ \\
\hline Outside air temperature & $(1)$ \\
\hline $\begin{array}{l}\text { Outlet or leaving water temperature from the tower } \\
\text { for both chillers (conditioned water return) }\end{array}$ & $(2)$ \\
\hline Chilled water supply temp from both chillers & $(2)$ \\
\hline $\begin{array}{l}\text { Hot water converter for secondary loop- entering } \\
\text { and leaving water temperatures for each }\end{array}$ & $(4)$ \\
\hline Hot water converter steam valve position for each & $12)$ \\
\hline Subtotal & 11 \\
\hline
\end{tabular}

Air handlers

\begin{tabular}{|l|c|l|c|}
\hline \multicolumn{1}{|c|}{ Name } & Tag number & \multicolumn{1}{|c|}{ Description of trend point } & $\begin{array}{c}\text { Number of points per } \\
\text { trend }\end{array}$ \\
\hline East AC & 1 & Mixed air temperature & $(1)$ \\
\hline East AC & 1 & Supply air temperature & $(1)$ \\
\hline East AC & 1 & Preheat valve position & $(1)$ \\
\hline East AC & 6 & Supply air temperature & $(1)$ \\
\hline West AC & 13 & $\begin{array}{l}\text { Hot deck and cold deck temperature } \\
\text { (multizone) }\end{array}$ & $(1)$ \\
\hline West AC & 15 & Supply air temperature & $(1)$ \\
\hline West AC & 15 & Chilled water valve position & $(7)$ \\
\hline Subtotal & & & \\
\hline
\end{tabular}




\begin{tabular}{|l|l|c|}
\hline \multicolumn{1}{|c|}{ Zones } & \multicolumn{1}{|c|}{ Description of trend point } & $\begin{array}{c}\text { Number of points per } \\
\text { trend }\end{array}$ \\
\hline Zone 3 & $\begin{array}{l}\text { Space temperature (facility } \\
\text { manager's office) }\end{array}$ & (1) \\
\hline West AC-15 & Return air temperature & (1) \\
\hline East AC-6 & Core space temperature & (3) \\
\hline Subtotal & & \\
\hline
\end{tabular}

Total points for trending during pre-implementation $=21$

The trends should be recorded at 10-minute intervals. Trending should be synchronized to start as close to the electronic data logging start time as possible (see short-term diagnostic plan for start times and dates during both pre-implementation and post-implementation testing).

\section{Post-implementation changes}

Trend points added:

(1)VFD on AC-12 and (2) humidity points for both the indoor and outdoor sensors Total points for trending during post-implementation $=24$ 


\section{Sample Functional Performance Tests}

Appendix $K$ contains a sample functional test for a centrifugal chiller and a variable frequency drive (VFD) on a pump. These tests can be more or less detailed and comprehensive, depending on budgets and project objectives. 


Functional Test Centrifugal Chiller

\begin{tabular}{|l|l|l|l|l|l|}
\hline Building: & $\begin{array}{l}\text { Commissioning } \\
\text { provider: }\end{array}$ & Phone: & \\
\hline Date: & $\begin{array}{l}\text { Manufacturer or } \\
\text { contractor: }\end{array}$ & & Phone: & \\
\hline
\end{tabular}

\section{Special Instructions:}

- Before performing this test, make sure that the normal preventive maintenance tasks have been completed for the chiller and the following related equipment has been observed or functionally tested to prove proper operation:

- Chilled water pumps

- Condenser water pumps

- Cooling towers

- Be sure all related pumps and cooling towers are operable and enabled

- Set leaving chilled water temperature to specified temperature

- If test is not being performed on or near design day temperatures, false load the chiller

- If an energy management control system (EMCS) interfaces with this chiller, make sure all sensors are calibrated and properly located

- Use monitoring (data loggers) and EMCS trend logging whenever possible to demonstrate proper operation of the equipment (this can be used in lieu of manual functional testing) and attach the output to this form

\section{Electrical}

- Check for voltage imbalance. Maximum allowable imbalance is $2 \%$.

- At the main disconnect for the compressors, measure the voltage of each phase and use the following method to determine the percent imbalance:

$$
\text { Phase } \mathrm{A}+\text { Phase } \mathrm{B}+\text { Phase } \mathrm{C} / 3=\text { Average voltage }
$$

- The percent voltage imbalance is then:

100 (average voltage - lowest phase) / the average voltage $=\%$ of imbalance

Measured voltage for compressors

\begin{tabular}{|l|l|l}
\hline Phase A: & Phase B: & Phase C: \\
\hline
\end{tabular}

Percent imbalance The percent imbalance is acceptable Yes/No

\section{Comments and calculations:}




\section{General}

Check operation or status of each. Enter comment number, if an item is deficient, and document comments by number in form provided below checklist. Use N/A for not applicable and N/O for not obtainable or available.

\begin{tabular}{|l|l|}
\hline Checklist item & \\
\hline Test condenser water flow and chilled water flow & \\
\hline Test interlocks to pumps & \\
\hline Test starter for dynamic limits and timers & \\
\hline Oil heater safety inhibits starting & \\
\hline Check chilled water recycle mode (if applicable) & \\
\hline Chilled water pump stays on & \\
\hline Other (list): & \\
\hline & \\
\hline & \\
\hline
\end{tabular}

\begin{tabular}{|l|l|}
\hline Number & Comment \\
\hline & \\
\hline & \\
\hline & \\
\hline & \\
\hline & \\
\hline
\end{tabular}

Test control panel for manual function

- Do readouts match actual values?

$\square$ Yes $\quad \square$ No

- Are refrigerant alarm and room ventilation adequate? $\square$ Yes $\square$ No

Confirm energy performance over load range. Compare results to manufacturer's data using the attached table. If using data loggers for this test, attach the readouts and explanation verifying proper performance; otherwise, proceed with manual test as follows:

- Take three sets of data at 10-minute intervals. Tolerances from specified values should not exceed $1^{\circ} \mathrm{F}$ for temperature and $5 \%$ for flow. Repeat if necessary until system stabilizes and the differences between the three readings are less than the limits. 


\begin{tabular}{|l|l|l|l|}
\hline Chilled water & Interval 1 & Interval 2 & Interval 3 \\
\hline LWT (F) & & & \\
\hline EWT (F) & & & \\
\hline Delta T & & & \\
\hline Flow in GPM & & & \\
\hline EW pressure (PSI) & & & \\
\hline LW pressure (PSI) & & & \\
\hline $\begin{array}{l}\text { Evaporator leaving } \\
\text { refrigerant temp. }\end{array}$ & & & \\
\hline
\end{tabular}

\begin{tabular}{|l|l|l|l|}
\hline Condenser water & Interval 1 & Interval 2 & Interval 3 \\
\hline LWT (F) & & & \\
\hline EWT (F) & & & \\
\hline Delta T & & & \\
\hline Flow in GPM & & & \\
\hline EW pressure (PSI) & & & \\
\hline LW pressure (PSI) & & & \\
\hline $\begin{array}{l}\text { Condenser leaving } \\
\text { refrigerant temp. }\end{array}$ & & & \\
\hline
\end{tabular}

\begin{tabular}{|l|l|l|l|}
\hline Electricity & Interval 1 & Interval 2 & Interval 3 \\
\hline Watt meter output & & & \\
\hline
\end{tabular}

Calculate the average test data and enter the results into the following table along with the manufacture's performance data:

Based on the average test data, calculate the capacity using the following formula:

CAP in cooling tons $=($ chilled water delta $T) *$ (chilled water flow rate) $/ 24$

Check operation or status of each. Enter comment number, if an item is deficient, and document comments by number in the form provided below the checklist. Use N/A for not applicable and N/O for not obtainable or available. 


\begin{tabular}{|l|l|l|l|}
\hline Chilled water & Manufacturer's data & Average test data & Comment \# \\
\hline LWT (F) & & & \\
\hline EWT (F) & & & \\
\hline Delta T & & & \\
\hline Flow in GPM & & & \\
\hline EW pressure (PSI) & & & \\
\hline LW pressure (PSI) & & & \\
\hline $\begin{array}{l}\text { Evaporator leaving } \\
\text { refrigerant temp. }\end{array}$ & & & \\
\hline LWT (F) & & & \\
\hline EWT (F) & & & \\
\hline Delta T & & & \\
\hline Flow in GPM & & & \\
\hline EW pressure (PSI) & & & \\
\hline LW pressure (PSI) & & & \\
\hline $\begin{array}{l}\text { Condenser leaving } \\
\text { refrigerant temp. }\end{array}$ & & & \\
\hline KW & & & \\
\hline BTU/h or cooling tons & & & \\
\hline kW per ton = & & & \\
\hline
\end{tabular}

\begin{tabular}{|l|l|}
\hline Number & Comment \\
\hline & \\
\hline & \\
\hline & \\
\hline & \\
\hline & \\
\hline
\end{tabular}

- Was any unusual noise or vibration observed?

- Were amperage fluctuations observed?

$\square$ Yes

$\square$ No

- Vane steady (not hunting)?

$\square$ Yes

$\square$ No

- Capacity is according to design?

$\square$ Yes

$\square$ No

- $\mathrm{kW}$ per ton is according to design?

$\square$ Yes

$\square$ No

$\square$ Yes

$\square$ No 


\section{Part Load Test}

Confirm energy performance over load range. Compare results to manufacturer's data using the attached table. If using data loggers for this test, attach the readouts and explanation verifying proper performance; otherwise, proceed with manual test as follows:

Chiller may need to run for 1 hour with temperature and flow rate stabilized before this test is performed. Watch amperage readings while load is being reduced. Amperage should be steady when recorded.

Take three sets of data at 10-minute intervals. Tolerances from specified values should not exceed $1^{\circ} \mathrm{F}$ for temperature and $5 \%$ for flow. Repeat if necessary until system stabilizes and the differences between the three readings are less than the limits.

\begin{tabular}{|l|l|l|l|}
\hline Chilled water & Interval 1 & Interval 2 & Interval 3 \\
\hline LWT (F) & & & \\
\hline EWT (F) & & & \\
\hline Delta T & & & \\
\hline Flow in GPM & & & \\
\hline $\begin{array}{l}\text { Evaporator leaving } \\
\text { refrigerant temp. }\end{array}$ & & & \\
\hline
\end{tabular}

\begin{tabular}{|l|l|l|l|}
\hline Condenser water & Interval 1 & Interval 2 & Interval 3 \\
\hline LWT (F) & & & \\
\hline EWT (F) & & & \\
\hline Delta T & & & \\
\hline Flow in GPM & & & \\
\hline $\begin{array}{l}\text { Condenser leaving } \\
\text { refrigerant temp. }\end{array}$ & & & \\
\hline
\end{tabular}

\begin{tabular}{|l|l|l|l|}
\hline Electricity & Interval 1 & Interval 2 & Interval 3 \\
\hline Wattmeter output & & & \\
\hline
\end{tabular}

Calculate the average test data and enter the results into the following table along with the manufacture's performance data:

Based on the average test data, calculate the capacity using the following formula: CAP in cooling tons $=$ (chilled water delta $T) *($ chilled water flow rate) $/ 24$ 


\begin{tabular}{|l|l|l|}
\hline Chilled water & Manufacturer's data & Average test data \\
\hline LWT (F) & & \\
\hline EWT (F) & & \\
\hline Delta T & & \\
\hline Flow in GPM & & \\
\hline EW pressure (PSI) & & \\
\hline LW pressure (PSI) & & \\
\hline Evaporator leaving refrigerant & & \\
temp. & & \\
\hline LWT (F) & & \\
\hline EWT (F) & & \\
\hline Delta T & & \\
\hline Flow in GPM & & \\
\hline EW pressure (PSI) & & \\
\hline LW pressure (PSI) & & \\
\hline $\begin{array}{l}\text { Condenser leaving refrigerant } \\
\text { temp. }\end{array}$ & & \\
\hline KW & & \\
\hline BTU/h or cooling tons & & \\
\hline KW per ton = & & \\
\hline
\end{tabular}
- Was any unusual noise or vibration observed?
$\square$ Yes
$\square$ No
- Were amperage fluctuations observed?
$\square$ Yes
No

\section{Chilled Water Reset}

If a reset strategy is employed, a test should be developed to demonstrate that the strategy works correctly. Use monitoring equipment or EMCS trend logging whenever possible and attach output demonstrating the reset strategy.

\section{Training}

- Are the staff responsible for operating the chiller adequately trained? $\square$ Yes $\square$ No Explain: 
O\&M Plan

- Has an acceptable O\&M Plan been put into place? $\square$ Yes $\square$ No

Briefly describe the O\&M plan:

The following items need correction:

- Are eddy current tests conducted every 5 years? $\square$ Yes $\square$ No 


\section{Variable Frequency Drive (VFD)}

Pump

Secondary Hydronic Pump Application

Functional Performance Test

\section{Commissioning team:}

Commissioning provider:

EMCS operator:

VFD technician:

HVAC technician:

Owner's representative:

Pumps ID:

Chilled water (CHW) secondary

Hot water secondary (HW)

Design max.:

$\mathrm{Hp}:$

GPM:

Head:

Ft:

VFD brand and model:

The following functional performance test is for a VFD controlling a variable flow hydronic system to a constant differential pressure (DP). A check-mark denotes compliance.

\section{Documentation Verification}

Review the design documents and the specifications if available.

Verify that the VFD description, troubleshooting guide and the installation, balance reports are on-site. specifications, technical and programming record and

From the design documents determine the location for the DP measurement:

Control strategy for the pump:

II. VFD Installation

Differential Pressure Sensor

Actual location of DP measurement

The measurement should ideally be taken across the coil of the last branch. 
Complies?

Pressure Offset (Po)Conversion: psi $\times 2.31=\mathrm{ft} \mathrm{H}_{2} \mathrm{O}$

DP pump is being controlled to: ___ feet $[A]$.

Pressure rise across pump at design conditions (from balance report): feet $[B]$. Pressure offset, Po, $[A] \div[B]=$

Optimally, Po should be 0.3 or less in order for the VFD and pump to be able to respond to small pressure changes and realize adequate energy savings. If Po is greater than 0.4 , the DP sensor is probably located too close to the pump.

Complies?

\section{Balancing to lowest pressure}

Review the HVAC balance report and verify that the system was balanced so that the VFD controls to the lowest possible DP (from the capacity test). The controlling DP from the balance report is feet. At design, the corresponding VFD frequency or pump RPM from the balance report is: Pump-1 The corresponding flow from the balance report is , Pump-2 _ Pump-3 test at the end of this form for details.

Balanced to lowest DP?

\section{General issues}

Verify that any power quality mitigation measures required from the specifications have been completed.

Verify that there are no three-way coil valves that may negate the value of the VFD by allowing flow to bypass the coil.

Verify that the acceleration and deceleration ramp time of the VFD is between 1 and 4 minutes. Actual ramp time: up $\mathrm{min} / \mathrm{down}$ min. Ishort ramp times will result in "hunting" and excess modulation by the VFD; typical ramp times are 1 to 4 minutes)

Verify that each VFD has been integrated into the EMCS according to specification.

Verify that the EMCS monitors the DP.

Verify that minimum flow bypass of 2-way valve, if present, has flow of less than $2 \%$ of design flow. 


\section{Functional Performance Test}

This test is not intended to verify that the coil valve is functioning properly, but rather that the VFD is functioning properly.

1. Design flow by test and balance (TAB). Record in Condition 1 in Table 1 the speed, $D P$, and total supply flow at design conditions from the TAB report.

2. Intermediate flow (coil valves partially open). Intermediate flow will occur when current conditions are such that the system is not in full cooling or full heating, nor at minimum flow. Read the speed, DP, and the total supply flow in the secondary loop and record in Condition 3 in Table 1.

If the conditions are not in an "intermediate" position, change all space temperature set points to 4 degrees below the actual temperature in the space for CHW pumps, or 4 degrees above for HW pumps (circle one) to simulate an approaching of thermostat satisfaction and take readings.

3. Design flow (coil valves full open). Using the EMCS or other means, change all space temperature set points to at least 10 degrees below the current space temperature for CHW pumps, or 10 degrees above for HW pumps, so that the entire HVAC system supplied from these pumps is in full cooling (or heating, as appropriate, circle) in all zones. Observe that all coil valves are to their design maximum position (from the TAB report). Wait at least 20 minutes for lag time while observing:

Does the first lag pump turn on (after a delay) when the lead pump exceeds its gpm design flow?

Does the second lag pump turn on (after a delay) when the sum Lead + Lag 1 exceeds the sum of their design, AND the DP drops to $80 \%$ or feet?

Read the speeds, DP and the total supply flow and record in Condition 2.

4. Minimum flow (coil valves shut). Change all space temperature set points to be equal to the actual space temperatures to simulate a satisfied condition, driving the boxes to their minimum and the coil valves closed. Wait at least 25 minutes.

Do the lag pumps sequentially turn off (with a delay) when the flow is less than the design of all running pumps?

Does the last pump shut off appropriately?

Take the frequency, pressure and flow readings and record in Condition 4. 
IV. Analysis

\begin{tabular}{|c|c|c|c|c|c|c|}
\hline \multicolumn{7}{|c|}{ Table 1} \\
\hline \multirow{2}{*}{ Condition } & \multirow{2}{*}{$\begin{array}{l}\text { Secondary } \\
\text { pump no. }\end{array}$} & \multicolumn{2}{|c|}{$\begin{array}{c}\text { Speed } \\
\text { (Hz or RPM) }\end{array}$} & \multicolumn{2}{|c|}{ DP at sensor (psi) } & \multirow{2}{*}{$\begin{array}{l}\text { Total } \\
\text { Flow } \\
\text { (gpm) }\end{array}$} \\
\hline & & Reading & Average & Reading & Average & \\
\hline \multirow{3}{*}{ 1. At design flow by $T A B$} & Lead & & & & & \\
\hline & Lag-1 & & & & & \\
\hline & Lag-2 & & & & & \\
\hline \multirow{3}{*}{$\begin{array}{l}\text { 2. At design flow (during } \\
\text { commissioning) }\end{array}$} & Lead & & & & & \\
\hline & Lag-1 & & & & & \\
\hline & Lag-2 & & & & & \\
\hline \multirow{3}{*}{$\begin{array}{l}\text { 3. At intermediate flow } \\
\text { (during commissioning) }\end{array}$} & Lead & & & & & \\
\hline & Lag-1 & & & & & \\
\hline & Lag-2 & & & & & \\
\hline \multirow{3}{*}{$\begin{array}{l}\text { 4. At no flow (during } \\
\text { commissioning) }\end{array}$} & Lead & & & & & \\
\hline & Lag-1 & & & & & \\
\hline & Lag-2 & & & & & \\
\hline
\end{tabular}

Conversion: $0.434 \times \mathrm{ft} \mathrm{H}_{2} \mathrm{O}=$ psi

$2.31 \times \mathrm{psi}=\mathrm{ft} \mathrm{H}_{2} \mathrm{O}$

1. In Table 1, average the speed and the DP for all pumps at each of the four conditions.

2. If the speed at Condition 1 (TAB test) is not within $10 \%$ of the current test at Condition 2, all the boxes may not have been driven wide open during the commissioning test, or the readings may have been taken before the lag time was complete. Investigate and repeat tests as appropriate. Less than $10 \%$ variance?

3. During operation of lead-lag pump combinations, the average DP readings at all four conditions should remain within $10 \%$ of each other. If there is more than a $10 \%$ variance, the sensor may be faulty. Note that during lead-lag pump transition, the DP may appropriately vary by as much as $20 \%$.

Less than $10 \%$ variance?

4. At no flow, Condition 4, are the flow and DP zero? 
5. For the total flow readings in Table 1 , are the values in Condition $2>3>4$ ?

6. Collaborative trending

The system operation will, will not (circle) be trended to further verify the proper .operation of the VFD. Points to be trended are listed in the Trending Request Form.

Based on studying the trends, is the VFD functioning properly?

7. Additional tests. Refer to the chilled water systems sequence of operations tests for further collaboration on the VFD performance.

\section{Training}

The building staff are adequately trained to operate and maintain the VFD.

Comments:

VI. O\&M Plan

An acceptable O\&M plan has been put into place. Describe:

\section{Capacity Test}

To ensure that energy use is minimized, the hydronic system must be balanced at design conditions at the lowest DP possible. This requires that the lowest possible DP at the sensor be found that will allow the delivery of design flow through the valve most difficult to satisfy. This system minimum DP is what the VFD should control to. This is accomplished by changing the temperature setpoint for all zones to $55^{\circ} \mathrm{F}$ for cooling coils or $85^{\circ} \mathrm{F}$ for heating coils, causing all AHU coil valves to be calling for full cooling or heating, as applicable. Each coil's flow is then measured against the design flow. The coil that is receiving the lowest fraction of design is identified. The current DP at the controlling sensor is noted. A calculation is made, giving the DP required at the sensor to allow the identified most critical coil to meet its design flow. The equation is $D P_{2}=D P_{1} \times Q_{2}{ }^{2} / Q_{1}{ }^{2}$, where $Q_{1}=$ actual or fraction of design flow during capacity test. $\mathrm{Q}_{2}=$ design flow or 1.0 if using fractions. $D P_{1}=D P$ at sensor. $D P_{2}=$ DP to control to. It is noted that if all coils were calling for full cooling simultaneously, the pump could not maintain the new $\mathrm{DP}_{2}$ value because a diversity pump size reduction had been made by the design engineer.

Summarize deficiencies and possible improvements on Master List 


\section{DISTRIBUTION}

\section{INTERNAL}

1. G. E. Courville

2. S. G. Hildebrand

3. J. M. MacDonald

4. M. A. Martin

5-274. T. R. Sharp

275. R. B. Shelton

276. R. L. Shelton

277. Central Research Library

278. Laboratory Records - RC

\section{EXTERNAL}

279. Lilia A. Abron, PEER Consultants, P.C., 1460 Gulf Blvd., 11 th Floor, Clearwater, Florida 34630

280. Susan L. Cutter, Department of Geography, University of South Carolina, Columbia, South Carolina 29208

281-330. Carolyn Dasher, Portland Energy Conservation, Inc., 921 SW Washington, Suite 312, Portland, OR, 97205

331-332. Peter Herzog, Herzog/Wheeler and Associates, 2183 Summit Ave., St. Paul, MN 55101

333. William Pletz, 14385 S.W. Wilson Dr., Beaverton, OR 97008

334. P. Richard Rittelmann, Burt Hill Kosar Rittelmann Associates, 400 Morgan Center, Butler, Pennsylvania 16001-5977

335. Susan F. Tierney, The Economic Resource Group, Inc., One Mifflin Place, Cambridge, Massachusetts 02138

336. C. Michael Walton, Department of Civil Engineering, University of Texas at Austin, Austin, Texas 78712-1076 